\title{
Cells of adult rat heart : isolation, characterization and some aspects of fatty acid metabolism
}

Citation for published version (APA):

Dormans-Linssen, M. C. J. G. (1993). Cells of adult rat heart : isolation, characterization and some aspects of fatty acid metabolism. [Doctoral Thesis, Maastricht University]. Datawyse / Universitaire Pers Maastricht. https://doi.org/10.26481/dis.19931124md

Document status and date:

Published: 01/01/1993

DOI:

10.26481/dis.19931124md

Document Version:

Publisher's PDF, also known as Version of record

\section{Please check the document version of this publication:}

- A submitted manuscript is the version of the article upon submission and before peer-review. There can be important differences between the submitted version and the official published version of record.

People interested in the research are advised to contact the author for the final version of the publication, or visit the DOI to the publisher's website.

- The final author version and the galley proof are versions of the publication after peer review.

- The final published version features the final layout of the paper including the volume, issue and page numbers.

Link to publication

\footnotetext{
General rights rights.

- You may freely distribute the URL identifying the publication in the public portal. please follow below link for the End User Agreement:

www.umlib.nl/taverne-license

Take down policy

If you believe that this document breaches copyright please contact us at:

repository@maastrichtuniversity.nl

providing details and we will investigate your claim.
}

Copyright and moral rights for the publications made accessible in the public portal are retained by the authors and/or other copyright owners and it is a condition of accessing publications that users recognise and abide by the legal requirements associated with these

- Users may download and print one copy of any publication from the public portal for the purpose of private study or research.

- You may not further distribute the material or use it for any profit-making activity or commercial gain

If the publication is distributed under the terms of Article $25 \mathrm{fa}$ of the Dutch Copyright Act, indicated by the "Taverne" license above, 


\section{CELLS OF ADULT RAT HEART}

Isolation, characterization and some aspects of fatty acid metabolism 
CIP-GEGEVENS KONINKLIJKE BIBLIOTHEEK, DEN HAAG

Dormans-Linssen, Maria Caroline Jacqueline Gerarda

Cells of adult rat heart : isolation, characterization and some aspects of fatty acid metabolism / Maria Caroline Jacqueline Gerarda Dormans-

Linssen. - Maastricht : Universitaire Pers Maastricht. -lll.

Thesis Maastricht. - With ref. - With summary in dutch.

ISBN 90-5278-104-4

Subject headings: cells / heart / lipid metabolism

() 1993 MCJG Dormans-Linssen, Maastricht 


\title{
CELLS OF ADULT RAT HEART \\ Isolation, characterization and some aspects of fatty acid metabolism
}

\section{PROEFSCIRIFT}

ter verkiyging wan de grad wan doctor aan de Rijsuniversiteit Limburg te Maastricht, op gezag van Rector Magnificus, Prof. Dr. H. Philipsen, volgens het besint wan het college wan Dekanen, in het openbaar te verdediger op woensdag, 24 nowember 1993 on 14.00 nur

\author{
doot
}

Maria Caroline Tacqueline Gerarda Domans-Linssen geboren te Venlo in 1959 


\section{Promotores:}

Prof. Dr. G.J. van der Vusse

Prof. Dr. R.S. Reneman

\section{Beoordelingscommissie:}

Prof. Dr. J.W. Arends, voorzitter

Prof. Dr. M. Borgers

Dr. C.A. Bruggeman

Dr. V. van Hinsbergh (Gaubius Laboratorium, IVVO-TNO, Leiden) Prof. Dr. R.F.A. Zwaal

Financial support by the Netherlands Heart Foundation and Stichting Wetenschappelijk Durrer Fonds for the publication of this thesis is gratefully acknowledged.

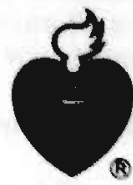


Hartelijk dank iedereen, die op een of andere manier heeft bijgedragen aan het tot standkomen van dit proefschrift.

Aan mijn ouders 


\section{LIST OF ABBREVIATIONS}
AA : arachidonic acid
BSA : bovine serum albumin
CEC : cardiac endothelial cells
CFLC : cardiac fibroblast-like cells
CMC : cardiomyocytes
CoA : coenzyme A
DiI-Ac-LDL : 1,1'-dioctadecyl-1-3,3,3',3'-tertramethyl-indocarbocyanine
FA : fatty acids
EDTA : ethylenediaminetetraacetate
FABP : fatty acid binding protein
FACS : fluor activated cellsorter
FCS : fetal calf serum
HBSS : Hanks' balanced salt solution
HEPES : 2-(4-(2-hydroxy ethyl)-1-piper-azinyl)-ethanesulfonic acid
HETE : hydroxyeicosatetraenoic acid
HHT : 12-hydroxyheptadecatienoic acid
HPLC : high performance liquid chromatography
HUVEC : human umbilical vein endothelial cells
ICAM : intercellular adhesion molecule
IFN : interferon
LT : leukotriene
MHC : major histocompatibility complex
MKR : modified Krebs Ringer buffer
PBS : phosphate buffered saline
PG : prostaglandin
PL : : phospholipids
RECA : rat endothelial cell antibody
RHEC : rat heart endothelial cell line
TG : triacylglycerols
TLC : thin liquid chromatography
Tx : thromboxane
VWF : Von Willebrand Factor 


\section{CONTENTS}

\section{Abbreviations}

Chapter 1 Introduction

1.1 Functional morphology of the heart 10

1.2 Lipid metabolism under normoxic and hypoxic conditions $\quad 12$

1.3 Aim of the study and outline of the thesis 14

1.4 References 15

Chapter 2 Isolation and cultivation of rat heart cells

2.1 Introduction 20

2.2 Initial isolation methods 20

2.3 Final isolation procedure $\quad 22$

2.4 Characterization of cells 25

2.5 Summary 29

2.6 References 29

Chapter 3 Continuous endothelial cell lines obtained from rat heart

3.1 Introduction 32

3.2 Methods 32

3.3 Results and discussion 36

3.4 Summary 41

3.5 References 41

Chapter 4 Fatty acid oxidation capacity and fatty acid-binding protein content of different cell types isolated from rat heart

4.1 Introduction 44

4.2 Methods 44

4.3 Results 45

4.4 Discussion $\quad 47$

4.5 Summary 48

4.6 References 49

Chapter 5 Production of arachidonic acid metabolites in adult rat cardiac myocytes, endothelial cells, and fibroblast-like cells

5.1 Introduction $\quad 52$

5.2 Methods $\quad 53$

5.3 Results $\quad 58$

5.4 Discussion 64

5.5 Summary 68

5.6 References 69 
Chapter 6 Arachidonic acid incorporation in cardiomyocytes, endothelial cells and fibroblast-like cells isolated from rat heart

6.1 Introduction $\quad 74$

$\begin{array}{ll}6.2 \text { Methods } & 75 \\ 6.3 \text { Resuls } & 74\end{array}$

$\begin{array}{ll}6.3 \text { Results } & 78 \\ 6.4 \text { Discussion }\end{array}$

6.4 Discussion $\quad 82$

$\begin{array}{ll}6.5 \text { Summary } & 85 \\ 6.6 \text { Refencs } & 85\end{array}$

6.6 References 85

Chapter 7 General discussion and conclusions

7.1 Discussion and conclusions $\quad 88$

$\begin{array}{ll}7.2 \text { References } & 91\end{array}$

Summary

93

Samenvatting $\quad 95$

$\begin{array}{lr}\text { Publications } & 97\end{array}$

$\begin{array}{ll}\text { Curriculum Vitae } & 99\end{array}$ 
CHAPTER 1

INTRODUCTION 


\subsection{FUNCTIONAL MORPHOLOGY OF THE HEART}

During evolution from one to multicellular organisms a circulatory system developed to transport nutrients and waste products to and from the various parts of the body, respectively. In order to keep this system in a operational state, a contractile organ capable of periodically propelling blood through the circulatory system developed as well.

Since this organ, the heart, is never in rest, chemical energy is continuously converted into mechanical energy. The contractile function of the heart is regulated by an intricate system of signal transduction, involving transmembrane fluxes of cations, such as $\mathrm{Na}^{+}, \mathrm{K}^{+}$and $\mathrm{Ca}^{2+}$. Chemical energy is provided by oxidative degradation of fatty acids, glucose and lactate supplied to cardiac cells from the blood in the cardiac capillary network.

The pump function of the heart and the circulation of blood was first described by Harvey (1578-1657, ref. 11). In cardiovascular physiology, experiments with in situ hearts and intact isolated hearts, first by Langendorff (17) and later on by many other investigators, have improved our understanding of fundamental metabolic processes. The obligatory role of oxygen in cardiac energy conversion and of $\mathrm{Ca}^{2+}$ in cardiac contraction became evident. Even nowadays the isolated intact working heart is an important tool in cardiovascular research. More than in the past, it is appreciated that the complex cellular organization of the heart requires a different experimental approach to elucidate fundamental questions related to cardiac function. Studies on intact hearts provide overall information on cellular performance not discerning the contribution of different cell types. Since each cell type has unique properties investigations on isolated cells and cell lines are required. The last 20 years isolation and culturing of cells has become a well accepted technique that provides a means to study basic physiological properties of individual cells, as far as their enzyme content, receptors, transduction systems, and gene regulation are concerned. In turn these experimental findings have lead to concepts with potention for therapeutic interventions. However, it should be kept in mind that in addition to the use of isolated cells, experiments on whole organs are necessary, because cells may behave differently in vitro and in vivo, while interactions between various cell types may occur when located in their natural environment.

The cellular organization of the mammalial heart is perfectly adapted to its function. About $75 \%$ of the heart mass is made up of muscle cells, i.e., cardiomyocytes with contractile properties. The remaining part of the heart consists of blood vessels and interstitial space. In the latter compartment connective tissue cells, conductive tissue cells and macrophages are present.

One gram of cardiac tissue contains on the average $2.10^{7}$ cardiomyocytes. Ventricular myocytes are about $25-50 \mu \mathrm{m}$ in diameter and $100-150 \mu \mathrm{m}$ in length $(1,2,9,12)$. The cell membrane or sarcolemma invaginates into the interior of the cell to form an extensive tubular network. 
A

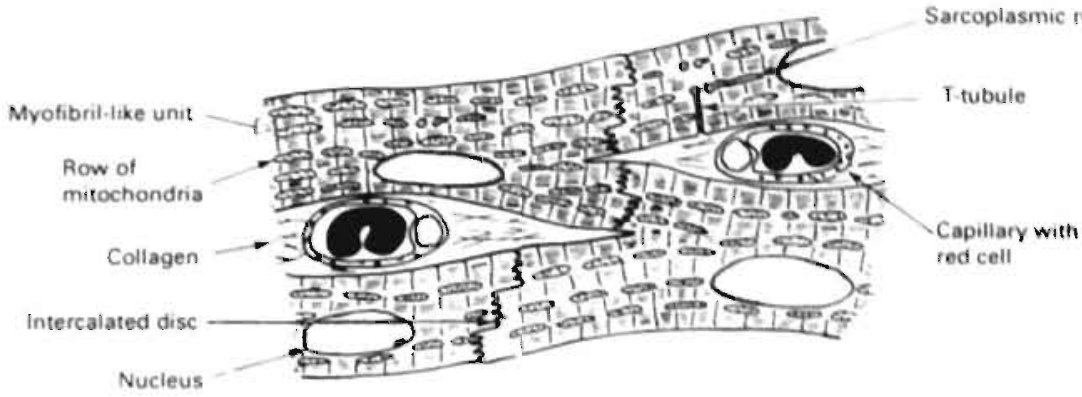

B

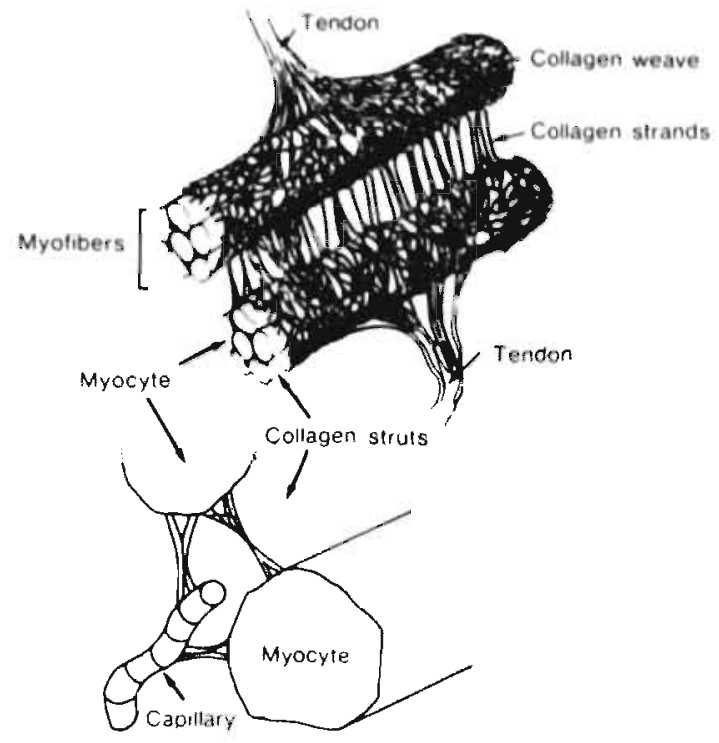

Figure 1.1. A: Schematic representation of the ultrastructure of cardiomyocytes surrounded by collagen and capillaries. From; An introduction to cardiovascular physiology. Ed. JR Levick, Buttenworth \& Co London, 1991, with permission of the publishers. B: schematic representation of the collagen matrix of the normal left ventricle. From; The heart, physiology and metabolism. Ed. LH Opi, Raven Press New York, 1991, with permission of the publisher.

The cells are for more than $80 \%$ binucleated $(6,16)$ and are filled with myofibrils and many mitochondria, lipid droplets and glycogen granules. The myofibrils are composed of actin and myosin filaments and are connected to the fascia adherent of the intercalated discs, i.e., specific areas of the sarcolemma between neighbouring cells (fig. 1.1a). The sarcolemma is covered with a layer of glycoproteins, the "glycocalyx". Myocytes are connected to other myocytes and their adjacent capillaries by struts of collagen (a fibrous material). Groups of myocytes form a myofiber that is held together by a collagen network. Further strands of collagen connect myofibers to each other (fig. 1.1b).

The cells building up the vessel wall are different in size and properties. Endothelial cells cover the inner surface of the blood vessels and form a 
continuous monolayer. They comprehend $2-3 \%$ of cardiac cell mass and $90 \%$ of the endothelial cells are of capillary origin $(1,2,12)$. Endothelial cells have a length of absut $25 \mu \mathrm{m}$, a width of about $10 \mu \mathrm{m}$ and a thickness of $0.2-0.5 \mu \mathrm{m}$ and are thus much smaller than cardiomyocytes (29). However, in the adult heart they are more abundantly present than cardiomyocytes (about $2.10^{8}$ endothelial cells/gram wet weight $(3,28,36)$. In situ the endothelial cells are elongated with the long axis aligned with the blood stream. Beside the nucleus, which extends into the vascular lumen, mitochondria, endoplasmatic reticulum and Golgicomplex have been identified. In the cytoplasm several intermediate filaments can be seen. The "glycocalyx", surrounding the endothelial cell membrane, forms at the abluminal side a basal lamina that contains heparan and chondroitin sulfates, collagen, proteoglycans and other glycoproteins. Endothelial cells have an important barrier function and can synthesize and secrete biologically active compounds into the vascular compartment and/or the subendothelial matrix (13, 29). The endothelial cells are surrounded by pericytes or smooth muscle cells, depending on their position in the vascular tree. Pericytes cover (in part) capillary endothelial cells and are together with the endothelial cells surrounded by the basal lamina $(1,21)$. Smooth muscle cells lie round arterioles, venules, arteries, and veins. The pericytes and smooth muscle cells are contractile cells and, hence, contribute to the regulation of blood flow through the coronary system. Beside the vascular cells and cardiomyocytes a variety of other cell types is found in the interstitial space of the heart. The presence of fibroblasts, nerve cells, macrophages, and mast cells has been established in the heart (1). The function and metabolic behavior of these cells vary substantially.

\subsection{LIPID METABOLISM UNDER NORMOXIC AND HYPOXIC CONDITIONS}

To fulfil its energy demands, the heart continuously extracts oxidizable substrates from the intravascular compartment. With respect to the nature of the substrates, the heart can be considered as an 'omnivorous' organ (34). Fatty acids, lactate and glucose are major fuels, but pyruvate, ketone bodies and amino acids are also potential sources of energy $(22,38)$. Under normal conditions the cardiomyocytes use predominantly fatty acids as fuel (24). The endothelial cells, however, prefer glucose and glutamine above fatty acids as energy source $(18,31)$. Fatty acids are not only important substrates for energy metabolism, but are also components of phospholipids, which are major constituents of cell membranes. They are important determinants of cellular integrity. Furthermore some polyunsaturated long-chain fatty acids are substrates for the synthesis of biologically active compounds, the eicosanoids.

Cardiac fatty acid metabolism is characterized by a complex of processes. Various storage forms are present and numerous lipid converting enzymes and transport routes are involved (for an extensive review see ref. 38 ). 
In blood, fatty acids are present as unesterified molecules complexed to albumin, or esterified in molecules as mono, di and triacylglycerols, phospholipids and cholesteryl esters. The triacylglycerols form the core of very low density lipoproteins or chylomicron particles. The fatty acyl moieties are hydrolyzed from the triacylglycerol molecules on the luminal side of the endothelium by the enzyme lipoprotein lipase, or released from the fatty acid-albumin complex by a yet not completely elucidated process in which the endothelial membrane is involved (fig. 1.2). From the vascular space the fatty acids have to pass several barriers before they reach the mitochondria of the cardiomyocytes where they are oxidized. First there is the endothelial lining. It has been hypothesized that transport of fatty acids occurs by lateral diffusion within the plasmalemma leaflets of endothelial cells $(26,27)$. More likely, fatty acids cross the endothelial luminal and abluminal membranes and diffuse through the cytoplasm (4).

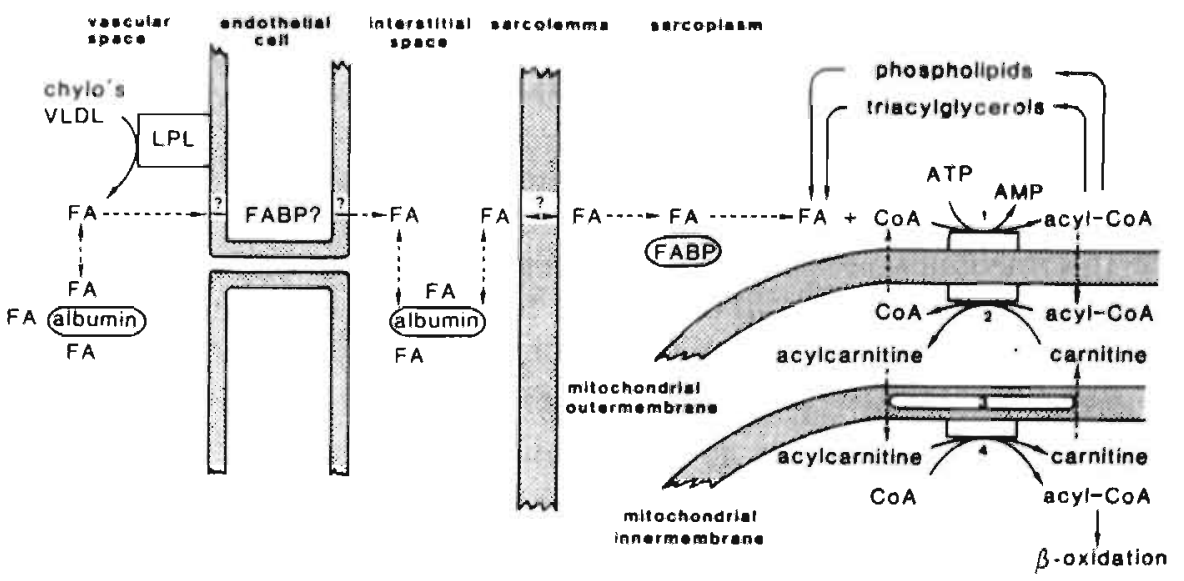

Figure 1.2. Schematical representation of uptake, transport, and activation of falty acids $(F A)$ in myocardial tissue. Numbers refer to enzymes involved: 1) acyl-CoA synthetase, 2) carnitine acyltransferase I, 3) carnitine acylcarnitine translocase, 4) carnitine acyltransferase II. FABP. fatty acid-binding protein. From; Van der Vusse et al. (ref. 38), with permission of the American Physiological Society.

The existence of carrier molecules for facilitation of transport of the hydrophobic fatty acids through the aqueous cytoplasm of endothelial cells is not clear yet. Subsequently the interstitial space has to be passed. This is most likely mediated by albumin. The translocation of the fatty acids from the interstitial space through the sarcolemma into the sarcoplasm could be explained by protein-mediated transfer $(30,33)$ or passive diffusion $(25)$, but the actual mechanism is incompletely understood. In the cardiomyocyte the intracellular translocation of fatty acids is facilitated by a tissue-specific cytoplasmic fatty acid-binding protein (FABP) $(10,14,32)$. 
Under normoxic conditions the fatty acids then are transported to the mitochondria and oxidized to produce energy. Parts of the fatty acids are temporarily stored in triacylglycerols, and a relative small quantity is incorporated in phospholipids and other complex lipids. The phospholipids are constituents of membranes and form a bilayer. The polar headgroups of the phospholipids form the outer surfaces of the two leaflets of the bilayer. The hydrophobic fatty acyl chains of phospholipids are buried in the lipophilic core of the lipid bilayer. A relatively small part, 5-10\%, of the cardiac phospholipids is located in the sarcolemma, the majority is localized in intracellular membranes (38). Phospholipids are in a continuous turnover process to reconstitute, among others, chemically modified phospholipid molecules and to adjust the biological properties of membranes to changes in cellular conditions. An important commonly present polyunsaturated fatty acyl moiety of membrane phospholipids is arachidonic acid. This fatty acid serves also as precursor for the synthesis of eicosanoids.

During reduced coronary flow (ischemia) to the heart, supply of substrates and removal of waste products is hampered. The oxidation of fatty acids becomes depressed and the heart anaerobically metabolizes carbohydrates $(19,23)$. Prolonged ischemia results in increased turnover of the cardiac triacylglycerol pool and disturbed resynthesis, and degradation of membrane phosholipids. Hereby various fatty acyl-containing intermediates accumulate $(7,20,37)$. Some of these intermediates seem to have a deleterious effect on the myocardium. Restoration of flow (reperfusion) only partly results in normalization of fatty acid metabolism, depending on the duration of ischemia $(5,35)$. Experimental findings indicate that the production and release of eicosanoids is enhanced in the postischemic heart $(8,15)$.

Fatty acid homeostasis in cardiac tissue has been extensively investigated during the past two decades. Although many basic questions regarding the metabolism of fatty acids under normal and ischemic conditions have been clarified, information about differences in fatty acid handling between the different cell types present in the heart is relatively scarce. This information is needed to understand the specific role of each cell type in overall cardiac fatty acid homeostasis and to elucidate the interplay between cardiac cells with respect to uptake, transport and enzymatic conversion of fatty acyl moieties.

\subsection{AIM OF THE STUDY AND OUTLINE OF THE THESIS}

The main purpose of the present study was to investigate a variety of aspects of fatty acid metabolism in cells isolated from cardiac tissue.

The first aim was to develop and implement techniques to isolate cardiomyocytes, endothelial cells and fibroblasts from adult rat hearts. These cell types were 
primarily selected since they are thought to play an important role in overall cardiac fatty acid homeostasis.

In chapter 2, a detailed description is given of the techniques currently used in our laboratory to isolate myccytes, endothelial cells and fibroblast-like cells from the heart. Cardiomyocytes were used for metabolic studies within 24 hours after isolation. Endothelial cells and fibroblast-like cells were cultured to increase the number of cells, since appreciable amounts of material are needed for biochemical/physiological studies. Efforts were made to immortalize endothelial cell cultures to obtain stable cell lines. Two successful attempts are described in chapter 3 .

Fatty acid homeostasis is characterized by a multitude of transport routes and metabolic conversions. Intracellular transport is thought to be mediated by cytoplasmic FABP. In chapter 4 the cellular content of heart-type FABP, as assessed in cardiomyocytes, endothelial cells and fibroblast-like cells is described. The FABP content is related to the maximal capacity to oxidize fatty acids.

Cardiac tissue has the the ability to produce a variety of eicosanoids, compounds with specific biological activity, from endogenous and exogenous substrates. Since the maximal capacity to synthesize eicosanoids in various cardiac cell types is largely unknown, the conversion of exogenous arachidonic acid into eicosanoids by isolated cardiomyocytes, and cultured endothelial cells and fibroblast-like cells was investigated. The results of these studies are presented in chapter 5.

In cardiac tissue arachidonic acid is mainly present in membrane phospholipids. In order to get more insight into the kinetics of incorporation of exogenous arachidonic acid in the esterified lipid pool of various cardiac cell types, the deposition of labeled arachidonic acid in isolated cardiomyocytes and cultured endothelial cells and fibroblast-like cells was studied under normoxic conditions. The fate of exogenously administered arachidonic acid was monitored by biochemical and autoradiographical techniques (chapter 6). Moreover, the total fatty acid content in the unesterified fatty acid pool, and in triacylglycerols and phospholipids was estimated with the use of gaschromatographical techniques (chapter 6).

In chapter 7, a general discussion on the isolation and culturing of cardiac cells is presented. Moreover, the results obtained on cellular fatty acid handling are discussed in a broader perspective.

\subsection{REFERENCES}

I Anversa P, Loud AV, Giacomelli F, Wiener J (1978) Absolute morphometric study of myocardial hypertrophy in experimental hypertension II. Ultrastructure of myocytes and interstitium. Lab Invest 38: 597-609 
2 Anversa P, Olivetti G, Melissari M, Loud A (1980) Stereological measurement of cellular and subcellular hypertrophy and hyperplasia in the papillary muscle of adult rat. J Mol Cell Cardiol 12: 781.795

3 Bai S, Campbell SE, Moorc JA, Morales MC, Gerdes AM (1990) Influence of age, and sex on cardiac myocyte size and number in rats. A nat Rec 226: 207-211

4 Bassingthwaighte JB, Noodleman L, Van der Vusse GJ, Glatz JFC (1989) Modeling of palmitate transport in the heart. Mol Cell Biochem 88: 51-59

5 Chatclain PI, Papagcorgiou I, Luthy P, Melchoir JP, Lerch R (1987) Free Fatty acid metabolism in "stunned" myocardium. Basic Res Cardiol 82 Suppl 1: $169-176$

6 Claycomb WC, Palazzo M (1980) Culture of the terminally differentiated adult cardiac muscle cell: a light and scanning microscope study. Develop Biol 80: 466-482

7 Corr PB, Gross RW, Sobel BE (1984) A mphipathic metabolites and membrane dysfunction in ischemic myocardium. Circ Res 55: 135-154

8 Engels W, Van Bilsen M, De Groot MJM, Reneman RS, Van der Vusse GJ (1990) Ischemia and reperfusion induced formation of eicosanoids in isolated rat hearts. Am J Physiol 258 : H1865-H1871

9 Fraticelli A, Josephson R, Danziger R, Lakatta E, Spurgeon H (1989) Morphological and contractile characteristics of rat cardiac myocytes from maturation to senescence. Am $J$ Physiol 257: $\mathrm{H} 259-\mathrm{H} 265$

10) Glatz JFC, Van der Vusse GJ (1989) Intracellular transport of lipids. Mol Cell Biochem 88: 37 44

11 Harvey W (1648) The works. Translated by Londen WR. Sydenham Society, 1847

12 Hyde DM, Buss DD (1986) Morphometry of the coronary microvasculature of the canine left ventricle. Am J Anat 177: 415-425

13 Jaffe EA (1987) Cell biology of endothelial cells. Hum Pathol 18: 234239

14 Kaikaus RM, Bass NM, Ockner RK (1990) Functions of fatty acid binding proteins. Expericnta 46: 617-630

15 Karmazyn M (1989) Synthesis and relevance of cardiac eicosanoids with particular emphasis on ischemia and reperfusion. Can J Physiol Pharmacol 67: 912-921

16 Kellerman S, Moore JA, Zierhut W, Zimmer H-G, Campbell J, Gerdes AM (1992) Nuclear DNA content and nucleation patterns in rat cardiac myocytes from different models of cardiac hypertrophy. J Mol Cell Cardiol 24: 497-505

17 Langendorff O (1895) Untersuchungen am ubberlebenden Saugetierherzen. Pflügers Arch 61: 291-332

18 Leighton B, Curi R, Hussein A, Newsholme EA (1987) Maximum activities of some key enzymes of glycolysis, glutaminolysis, Krebs cycle and fatty acid utilization in bovine pulmonary endothelial cells. FEBS letl 225: 93-96

19 Lerch RA, Bergmann SR, Ambos HD, Welch MJ, Ter-Pogossian MM, Sobel BE (1985) Effect of flow-independant reduction of metabolism on regional myocardial clearance of ${ }^{11} \mathrm{C}$ pelmitate. Circulation 65: 731-738

20 Liedtke AJ (1981) Alterations of carbohydrate and lipid metabolism in the acute ischemic heart Prog Cardiovase Dis 23: 321.336

21 Melax H, Leeson TS (1972) Electron microscope study of myocardial tissue space contents in rat heart. Cardiovasc Res 6: 89-94

22 Neely JR, Rovelto MJ, Oram JF (1972) Myocardial utilization of carbohydrate and lipids Progress in cardiovascular diseases 15: 289-329

23 Opie LH (1968) Metabolism of the heart in health and disease. Part I. Am Heart J 76: 685-698

24 Probst I, Spahr R, Schweickhardt C, Hunneman DH, Piper HM (1986) Carbohydrate and fatty acid metabolism of cultured adult cardiac myocytes. Am J Physiol 250: H853-H860

25 Rose H. Hennecke T. Kammermeier H (1989) Is fatty acid uptake in cardiomyocytes determined by physicochemical fatty acid partition and membranes? Mol Cell Biochem 88: 31 36

26 Scow RO, Blanchette-Mackie EJ (1985) Why fatty acids flow in cell membranes. Prog Lipid Res 24: 197-241

27 Scow RO, Blanchette-Mackie EJ, Smith LC (1980) Transport of lipid across capillary endothelium. Fed Proc 39: 2610-2617 
28 Simionescu M. Simionescu (1978) Isolation and characterization of endothelial cells from the heart microvaculature. Microvase Res 16: 426-452

29 Simionescu M. Simionescu N (1986) Functions of endotheltal cell surface. Ann Rev Physiol 48: $279-293$

30 Sorrentino D, Robinson RB, Kiang CL, Berk PD (1989) At physiological albumin/oleate concentrations uplake by isolated hepatocytes, cardiac myocytes and adipocytes is a saturable function of the unbound oleate concentration. Uptake kineties are consistent with the conventional theory. J Clin Invest 84: 1325- 1333

3I Spahr R, Krutzfeldt A, Mertens S, Siegmund B, Piper HM (1989) Fatty acids are not an important fuel for coronary microvascular endothelial cells. Mol Cell Biochem 88: 59-64

32 Spener R, Borchers T, Murkerjea M (1989) On the role of fatty acid binding proteins in fatty acid transport and metabolism. FEBS Lell 244: $1-5$

33 Stremmel W (1988) Fatty acid uptake by isolated rat heart myocytes represents a carriermediated transport process. J Clin Invest 81 : $844-852$

34 Tacgtmeyer H (1985) Carbohydrate interconversions and energy production. Circulation 72 . Suppl IV: $1-8$

35 Van Bilsen M, Van der Vusse GJ, Willemsen PHM, Coumans WA, Roemen THM, Reneman RS (1989) Lipid alterations in isolated, working rat hearts during ischemia and reperfusion: its relation to myocardial damage. Circ Res $64: 304-314$

36 Van der Laarse A, Hollaar L, Van der Valk EMJ, Hamers S (1989) A method to quantitate cell numbers of muscle cells and non-musele cells in homogenised heart cell cultures. Cardiovasc Res 23: 928-933

37 Van der Vusse GJ, Prinzen FW, Van Bilsen M, Engels W, Reneman RS (1987) Accumulation of lipids and lipid-intermediates in the heart during ischemia. Basic Res Cardiol 82 Suppl 1: $157-167$

38 Van der Vusse GJ, Glatz JFC, Stam HCG, Reneman RS (1992) Fatty acid homeostasis in the normoxic and ischemic hcart. Physiol Rev 72: 881-940 


\section{CHAPTER 2}

\section{ISOLATION AND CULTIVATION OF RAT HEART CELLS}

Parts of this chapter are published in

Linssen MCJG, Vork MM, De Jong YF, Glatz JFC, Van der Vusse GJ (1990) Fatty acid oxidation capacity and fatty acid-binding protein content of different cell types isolated from rat heart. Mol Cell Biochem 98: 19-25.

Linssen MCJG, Engels W, Lemmens PJMR, Heijnen VVTh, Van Bilsen M, Reneman RS, Van der Vusse GJ (1993) Production of arachidonic acid metabolites in adult rat cardiac myocytes, endothelial cells and fibroblast-like cells. Am J Physiol 264: H973-H982. 


\subsection{INTRODUCTION}

To elucidate fundamental questions related to cardiac function one has to understand the physiology of the various cell types present in the heart. Cardiomyocytes and vascular cells, especially the endothelial cells, but also fibroblasts, play a role in the cardiac metabolism. So, the use of isolated and cultivated cells and cell lines provides a tool to study the individual features of cardiac cells.

For the isolation of cells a variety of methods have been described depending on the organ they have to be harvested from. The isolation of cardiomyocytes mostly starts with a perfusion of the isolated (intact) heart according to Langendorff with a solution containing a proteolytic enzyme and is followed by mincing of the tissue in smaller pieces and a second digestion with enzymes $(4,8,15$,). A large variety of enzymes has shown to be successful in cardiomyocyte isolation, but mostly collagenase is used. This enzyme cleaves the cellular connections with the extracellular matrix. This treatment should be as short as possible to prevent damage to the myocytes themselves. The concentration of calcium in the perfusion medium was found to be critical in the procedure. It has to be low otherwise the $\mathrm{Ca}^{2+}$-dependent desmosome structures at the intercalated discs between neighboring myocytes do not dissociate. The $\mathrm{Ca}^{2+}$ concentration should not be too low to preserve the structure and function of the sarcolemma and its associated glycoproteins. Besides the proteolytic enzymes need calcium for activation $(4,7$, $8,15)$. During isolation the cardiomyocytes are sensitive to abrupt temperature changes and mechanical stress and have to be treated carefully.

For the isolation of endothelial cells several techniques have been described. From larger vessels endothelial cells can be dissociated by enzymatic digestion $(5,9,13)$ or are allowed to grow out of a vessel by the explant technique $(2,12)$. Endothelial cells from smaller arteries and veins and from microvessels are collected after perfusion with proteolytic enzymes $(3,14$,$) , or after enzymatic$ digestion of the (minced) organ $(16,17)$.

\subsection{INITIAL ISOLATION METHODS}

Several methods have been explored in our laboratory to obtain a pure fraction of rat heart endothelial cells. First we followed the procedure as described by Nees et al. (14). Hereby hearts were first retrogradely perfused with a Krebs-Henseleit buffer (KHB) containing: $127 \mathrm{mM} \mathrm{NaCl}, 4.6 \mathrm{mM} \mathrm{KCl}, 25 \mathrm{mM} \mathrm{NaHCO}_{3}, 1.1 \mathrm{mM}$ $\mathrm{MgSO}_{4}, 1.2 \mathrm{mM} \mathrm{KH}_{2} \mathrm{PO}_{4}, 2 \mathrm{mM}$ Na-pyruvate, $8.3 \mathrm{mM}$ glucose, $2.5 \mathrm{mM} \mathrm{CaCl}$, $1 \%$ phenolred and $\mathrm{pH} 7.4$. After 5 min the perfusion medium was changed to Collins A buffer $\left(43 \mathrm{mM} \mathrm{K} 2 \mathrm{HPO}_{4}, 15 \mathrm{mM} \mathrm{KH}_{2} \mathrm{PO}_{4}, 15 \mathrm{mM} \mathrm{KCl}, 10 \mathrm{mM}\right.$ $\left.\mathrm{NaHCO}_{3} ; \mathrm{pH} 7.4\right)$ containing several enzymes $(0.1 \%$ collagenase, $0.1 \%$ DNase and $0.1 \%$ papaine). Then the flow was switched off and the enzyme-solution, present in the coronary vessels, was allowed to dissociate the endothelial cells. Hereafter 
the coronary vessels were perfused with KHB and the perfusate was collected. This solution was centrifuged and the pelleted cells were purified with a $70 \%$ percoll gradient. The superficial fraction with a density of about 1.04 was collected, washed and plated on two $3.5 \mathrm{~cm}$ diameter culture dishes. The harvest from six rats before centrifugation on the percoll gradient was on the average $3.10^{5}$ cells. After a week of culturing the cells had divided and grown to confluency. Microscopic evaluation of the percentage positive cells, after three hours incubation with 1,1'-dioctadecyl-1-3,3,3',3'-tetramethyl-indocarbocyanineperchlorate-Acetylated Low Density Lipoprotein DiI-Ac-LDL (18) revealed that only $40-80 \%$ of the cells were of endothelial origin. Attempts to purify the culture after labeling of the endothelial cells with the fluorescent DiI-Ac-LDL and using a fluor activated cellsorter (FACS) were only partly successful. The risk of contamination was high and the yield was low. For qualitative analyses of endothelial cells this method was suitable. However for biochemical experiments this procedure was too complicated and too low in yield.

A second method for isolation of cardiac endothelial cells was performed according to the method described by Simionescu et al. (17) and modified by Piper (16). Hereby cardiomyocytes and endothelial cells are isolated from the same preparation. In this method rat hearts are first perfused according to the Langendorff technique with a modified Krebs Ringer buffer (MKR) containing: $115 \mathrm{mM} \mathrm{NaCl}, 2.6 \mathrm{mM} \mathrm{KCl}, 1.2 \mathrm{mM} \mathrm{KH}_{2} \mathrm{PO}_{4}, 1.2 \mathrm{mM} \mathrm{MgSO}_{4}, 10 \mathrm{mM} \mathrm{NaHCO}$, $10 \mathrm{mM}$ 2-(4-(2-Hydroxy Ethyl)-1-Piper-azinyl)-Ethanesulfonic acid (HEPES), 11 $\mathrm{mM}$ glucose, $4 \mathrm{mM}$ taurine; $\mathrm{pH}$ was set at 7.4 and the buffer solution was gassed with $95 \% \mathrm{O}_{2}$ plus $5 \% \mathrm{CO}_{2}$. After $10 \mathrm{~min}$ the perfusion medium was changed to MKR with $0.06 \%$ collagenase and $25 \mu \mathrm{M} \mathrm{CaCl}_{2}$. After 30 min recirculation with this solution at $37^{\circ} \mathrm{C}$, the heart was cut into small pieces and digested into single cells during a second incubation in MKR with $0.06 \%$ collagenase, $25 \mu \mathrm{M} \mathrm{CaCl}_{2}$ and $1 \%$ bovine serum albumin (BSA) V (essentialle fatty acid free). The solution was filtered and centrifuged at $25 \mathrm{~g}$ for $3 \mathrm{~min}$. The pellet consisted of cardiomyocytes, and the supernatant of endothelial and other cardiac cells. After a third incubation with $0.1 \%$ trypsin the latter mixed cell solution was plated on tissue culture dishes. Although the yield of cardiomyocytes was good, the endothelial cell preparation was not pure. After a week cultivation, on the average $15-50 \%$ endothelial cells were present. Efforts to purify the preparation with the FACS, after labeling with DiI-Ac-LDL, failed because the percentage of endothelial cells was too low to prevent contamination with non-endothelial cells. Rerun of the sorted endothelial positive fraction revealed that still 10-20\% nonendothelial cells were present. These DiI-Ac-LDL-negative cells overgrew the endothelial cells when placed in culture.

The method with which we finally succeeded to obtain a pure culture of endothelial cells is a modification and combination of the protocols as described by Diglio et al. (3) and Piper et al. (15) and is written hereafter (see also fig. 2.1). 


\subsection{FINAL ISOLATION PROCEDURE}

\section{Animals}

Hearts were removed from male adult Wistar or Lewis rats of 12 weeks old under ether anesthesia. The hearts were subsequently placed in ice-cold MKR. After cannulation of the aorta, the heart was perfused with $\mathrm{MKR}$ at $37^{\circ} \mathrm{C}$ according to the Langendorff technique with a constant coronary flow of 10 $\mathrm{ml} / \mathrm{min}$ for $10 \mathrm{~min}$ (washing period).

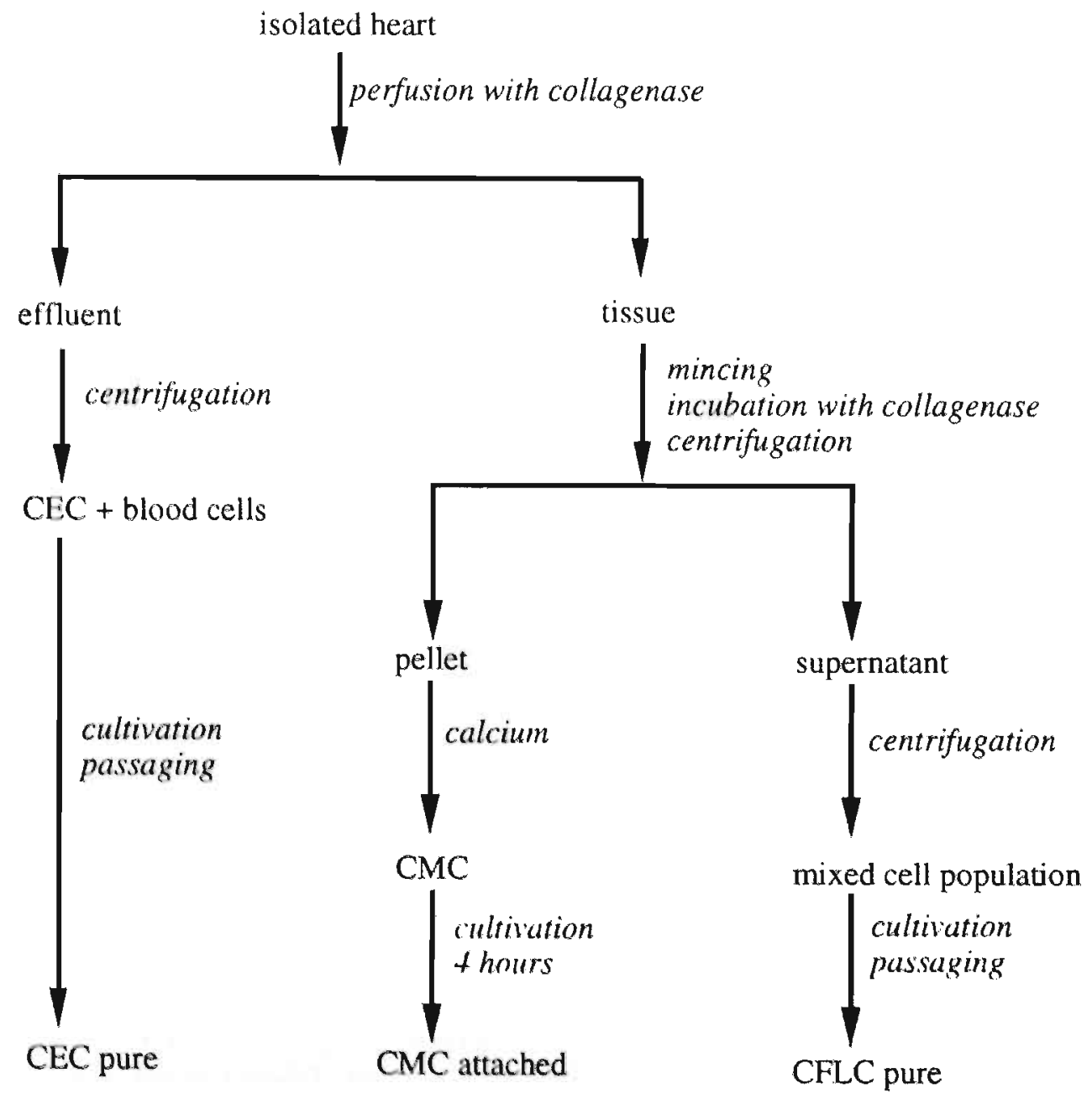

Figure 2.1. Schematic representation of the procedure for the isolation and cultivation of adult rat heart cells, CEC, cardiac endothelial cells, CMC, cardiomyocytes, CFLC, cardiac fibroblast-like cells. 


\section{Isolation of cells}

Cells were isolated from the hearts in sterile conditions. After the washing period (see above) the heart was recirculated with $50 \mathrm{ml} \mathrm{MKR} \mathrm{containing} 25 \mu \mathrm{M} \mathrm{CaCl}_{2}$ and $0.06 \%$ collagenase for $30 \mathrm{~min}$. Cardiac endothelial cells (CEC) were collected from the recirculation medium according to Diglio et al. (13). The heart was removed from the apparatus and blood vessels, atria and fibrous tissue were trimmed from the heart. Thereafter the ventricles were chopped and incubated in $20 \mathrm{ml} \mathrm{MKR}$ containing $25 \mu \mathrm{M} \mathrm{CaCl}, 0.06 \%$ collagenase and $1 \% \mathrm{BSA} \mathrm{V}$ (essentially fatty acid free) under gently pipetting the suspension for $30 \mathrm{~min}$ (25). The solution was filtered through a $200 \mu \mathrm{m}$ nylon sieve. Cells were either centrifuged at $25 \mathrm{G}$ for $90 \mathrm{~s}$ or allowed to settle down at room temperature during $10 \mathrm{~min}$. The pellet consisted predominantly of cardiomyocytes (CMC). This fraction was purified by washing before plating. The supernatant contained a mixed cell population consisting of fibroblasts, cardiomyocytes and smooth muscle, endothelial and blood cells. This supernatant was used for cultivation of cardiac fibroblast-like cells (CFLC).

The CMC pellet was washed three times in MKR with increasing concentrations of $\mathrm{Ca}^{2+}(0.2,0.5$ and $1 \mathrm{mM}$, respectively). CMC were collected by gravity at room temperature. The final pellet contained 2 to $5.10^{6}, 40-70 \%$ rod shaped CMC. This pellet was resuspended in CMC culture medium (M199, $2 \mathrm{mM} \mathrm{L-}$ glutamine, $13 \mathrm{mM} \mathrm{NaHCO} 3,10 \mathrm{mM}$ HEPES, $100 \mathrm{U} / \mathrm{ml}$ penicilline, $100 \mu \mathrm{g} / \mathrm{ml}$ streptomycine, 4\% fetal calf serum (FCS) from Boehringer and plated on tissue culture dishes. The dishes were precoated overnight with $\mathrm{CMC}$ culture medium. After 4 hours of culture at $37^{\circ} \mathrm{C}$ in a humidified $95 \%$ air plus $5 \% \mathrm{CO}_{2}$ stove, the rod shaped $\mathrm{CMC}$ were attached to the dishes and, then or overnight used in the experiments.

\section{Cultivation of endothelial and fibroblast-like cells}

The preparations containing either CEC (recirculation medium) or mixed cells (supernatant of the collected CMC) were centrifuged twice in CEC culture medium (40\% M199, 40\% RPMI1640, 20\% FCS, 2 mM L-glutamine, $13 \mathrm{mM}$ $\mathrm{NaHCO}_{3}, 10 \mathrm{mM}$ HEPES, $50 \mu \mathrm{g} / \mathrm{ml}$ gentamicine, $20 \mathrm{U} / \mathrm{ml}$ heparine and approximately $40 \mu \mathrm{g} / \mathrm{ml}$ bovine brain extract, prepared according to Maciag et al. (11)) supplemented with $2.5 \mu \mathrm{g} / \mathrm{ml}$ fungizone. The cells were resuspended in culture medium, plated on fibronectine $(100 \mu \mathrm{g} / \mathrm{ml})$ precoated Falcon dishes and placed in a humidified $95 \%$ air plus $5 \% \mathrm{CO}_{2}$ stove at $37^{\circ} \mathrm{C}$. Primary cultures were provided with fresh culture medium every day, passaged cultures every 2-3 days. When almost confluent, CEC were further purified by removing nonendothelial cells under the microscope according to Diglio et al. (13). In primary cultures of the mixed cell preparations $50-75 \%$ of the cells had a fibroblast-like (CFLC) appearance. Confluent CEC and CFLC were treated with phosphate buffered saline (PBS; $137 \mathrm{mM} \mathrm{NaCl}, 2.6 \mathrm{mM} \mathrm{KCl}, 8.1 \mathrm{mM} \mathrm{Na} \mathrm{HPO}_{4}, 1.5 \mathrm{mM}$, $\mathrm{pH} 7.4$ ), containing $0.67 \mathrm{mM}$ ethylenediaminetetraacetate (EDTA) and 1.25 $\mathrm{mg} / \mathrm{ml}$ trypsin to detach the cells, and subcultivated in CEC culture medium. 


\section{Characterization of cells}

The isolated myocytes were microscopically checked for cell morphology and trypan blue exclusion.

The primary cultures of CFLC and CEC were tested for the uptake of Dil-AcLDL (18). Cell cultures in Costar 96 well plates were incubated with $10 \mu \mathrm{g}$ DilAc-LDL/ml culture medium at $37^{\circ} \mathrm{C}$ for four hours. The medium was renewed and the cells were studied with a Zeiss fluorescence microscope equipped with the barrier filters BP 530-560, FT 580 and LP 590.

For immunofluorescence microscopy cell solutions were plated on Costar 96 well plates and grown to confluency. Cell monolayers were fixed in 3\% paraformaldehyde and treated with $0.05 \%$ Nonidet P40 to permeabilize the membranes as described by Laurila et al. (10). After washing three times in PBS, the cells were incubated with rabbit anti human-Von Willebrand Factor (VWF) (1) diluted 1:100 in PBS containing 1\% BSA and $0.1 \% \mathrm{NaN}_{3}$ in a humidified atmosphere at $37^{\circ} \mathrm{C}$ for $30 \mathrm{~min}$. Another well with cells was incubated with RECA-1 (a rat endothelial cell antibody, ref. 5) diluted 1:500 in PBS containing $1 \%$ BSA plus $0.1 \% \mathrm{NaN}_{3}$ at $37^{\circ} \mathrm{C}$ for $30 \mathrm{~min}$. After washing with PBS, cells were incubated with fluorescein isothiocyanate (FITC)-conjugated swine anti rabbitIgGs or FITC-conjugated rabbit anti mouse-JgGs. The cells were washed and mounted in glycin buffered glycerol ( $\mathrm{pH} 8.6$ ) for fluorescence microscopic evaluation with barrier filters BP 450-490, FT 510 and LP 515.

\section{Electron microscopy}

For transmission electron microscopy cells were grown on fibronectin precoated, thermanox tissue culture coverslips and fixed in a PBS solution containing $2 \%$ glutaraldehyde and $50 \mathrm{mM}$ L-lysine or $2 \%$ tannine. Thereafter a $60 \mathrm{~min} 2.5 \%$ glutaraldehyde fixation was performed. The cells were postfixed with $1 \%$ osmium tetroxide, stained en bloc with $2 \%$ uranyl acetate, dehydrated and embedded in epon. Ultrathin sections were briefly counterstained with lead citrate and examined with the electron microscope (EM 400, Philips).

\section{Materials}

The culture media RPMI1640, M199, fungizone and the trypsin solution were purchased from Gibco (Life Technologies Ltd., Paisley, Scotland UK); FCS batch 60045402 from Boehringer Mannheim GmbH (Mannheim, FRG). or batch 40G3700P from Gibco, or batch 701064 from Sera-Lab Ltd. (Crawley Down, UK) or batch 0135827 from Flow Laboratories Ltd. (Irvine, Scotland UK). Collagenase (CLS) batch $67047 \mathrm{M}$ was obtained from Cooper Biomedical Worthington (Malvern, PA USA) and BSA V (essentially fatty acid free), Lglutamine, L-lysine and DNase were obtained from Sigma Chemical Co. (St Louis, MO USA). BSA V from Boehringer Mannheim GmbH and heparin sodium from Serva GmbH (Heidelberg FRG). 
The Falcon tissue culture dishes were obtained from Becton Dickinson Ltd. (Playmouth, UK) and microtiter plates from Costar Corp. (Cambridge, MA USA). FITC conjugated antibodies were purchased from Dakopatts (Copenhagen, Denmark) and Dil-Ac-LDL from Biomedical Technologies Inc. (Stoughton. MA USA). RECAl was a gift from Dr. A.M. Duijvestijn (Department of Immunology, University of Limburg. The Netherlands). Fibronectin and rabbit polyclonal anti-Von Willebrand protein $\operatorname{lgG}$ were obtained from the Central Laboratory of the Netherlands Red Cross Transfusion Service (CLB, Amsterdam, The Netherlands).

Thermanox tissue culture coverslips were obtained from Miles Laboratories Inc. (Naperville, IL USA). Tannine was obtained from Mallinckrodt Inc. (Paris, TX USA), osmium tetroxide from Johnson Matthey (Herts, UK) and glutaraldehyde and uranyl acetate from Merck (Darmstadt, FRG).

\subsection{CHARACTERIZATION OF CELLS}

\section{Morphology and immunocytochemistry}

From adult rat hearts three different types of cells were isolated: cardiomyocytes $(\mathrm{CMC})$, cardiac endothelial cells (CEC) and cells that resembled fibroblasts in morphology and growth pattern and therefore were designated cardiac fibroblastlike cells (CFLC).

The cardiomyocytes, isolated from an adult rat heart have special features. They do not divide and keep their typical elongated morphology in culture for a certain time, but after a couple of days they can dedifferentiate and change from rod shaped to rounded cells when kept in medium with FCS. The isolated CMC were attached to dishes and were kept in culture overnight after isolation. Microscopic evaluation showed that over $95 \%$ of the cells did not take up trypan blue and were rod shaped (fig. 2.2a). They were mechanically at rest. Electron microscopically the CMC had a normal appearance; they contained myosin and actin filaments, densely stained glycogen particles and mitochondria with matrix granula (fig. 2.3a).

The CEC preparation consisted of positively identified endothelial cells (sce below). Whenever during the first culture non-typically growing cells were observed microscopically, these particular cells were removed from the plate as described by Diglio et al. (3). The remaining cells were allowed to grow to confluency. The CEC showed an elongated shape and formed a monolayer at confluency (fig. 2.2d). The CEC internalized Dil-Ac-LDL and stained positively with antibodies against Von Willebrand Factor and with an endothelial cell specific rat monoclonal antibody (RECA-1) (fig. 2.3). 

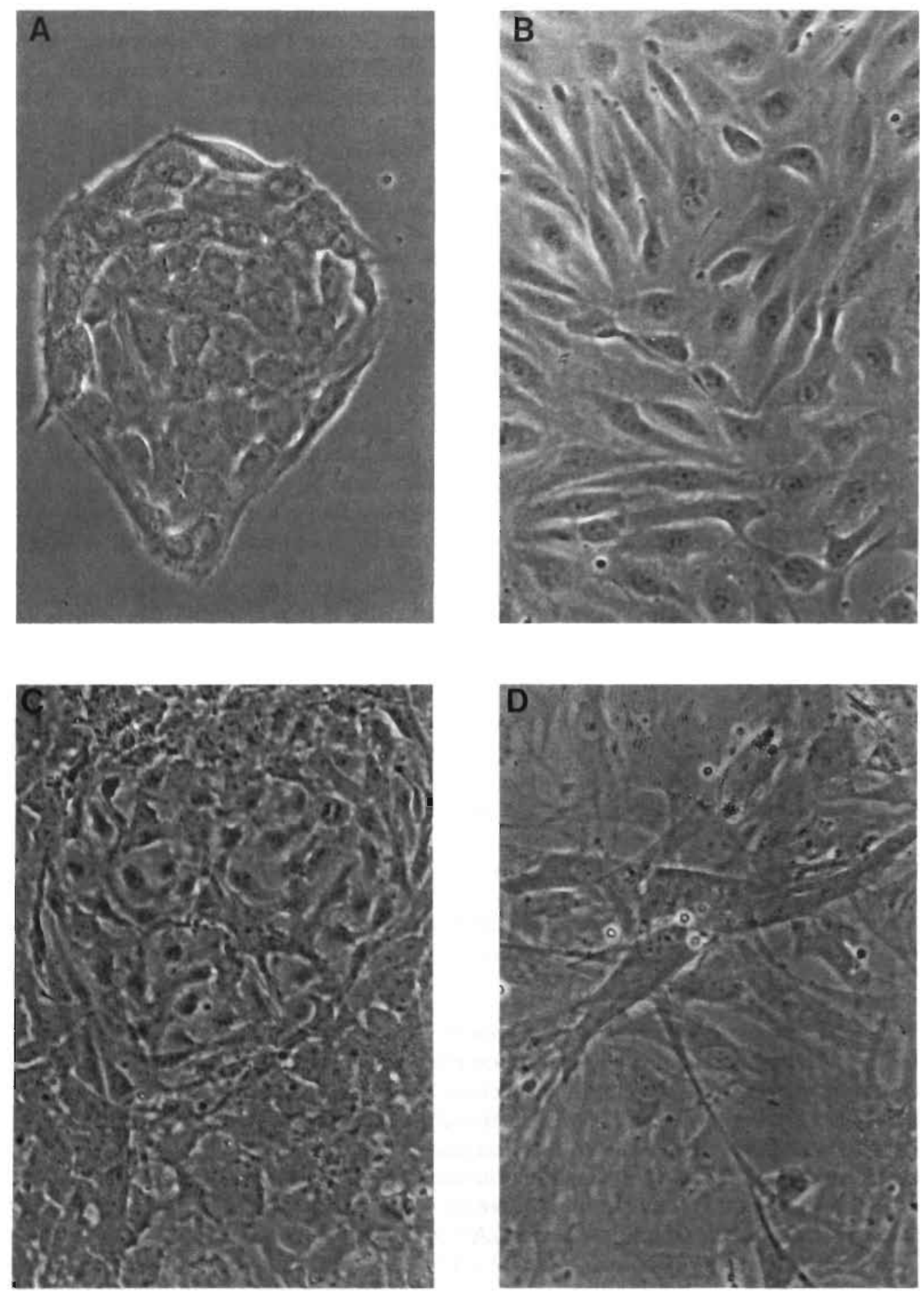


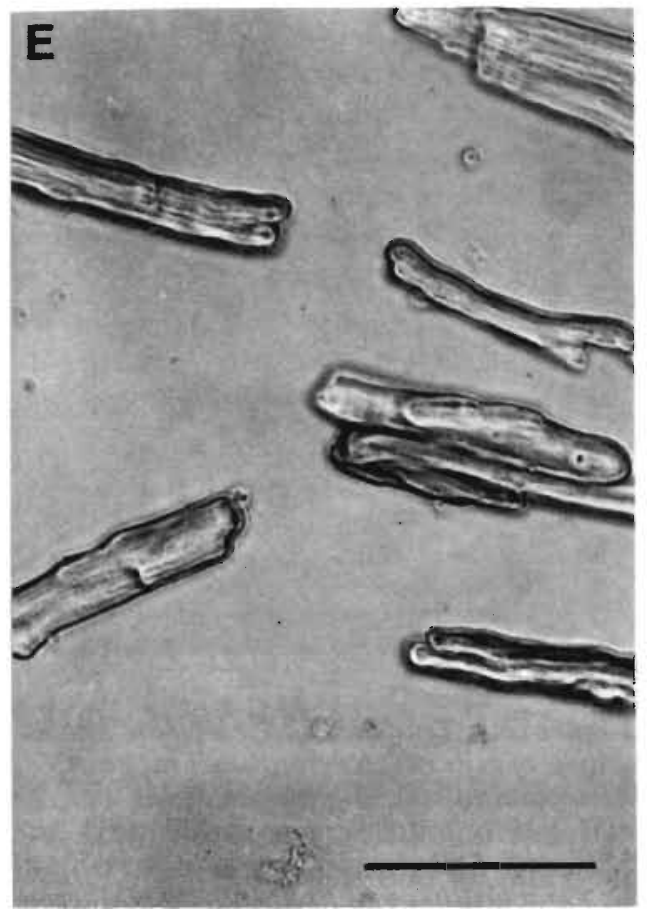

Figure 2.2. Phase contrast light micrographs of cardiomyocytes and cultured endothelial and fibroblast-like cells from adult rat heart.

A: primary culture of cardiac endothelial cells. $B$ : confluent endothelial cells passage 5.

C: primary culture of a mixed cell preparation with fibroblast.like cells surrounding a clone of endothelial cells.

D: Passaged fibroblast-like cells in a postconfluent siate.

$E$ : isolated cardiomyocyles.

Bar represents $0.1 \mathrm{~mm}$.

The primary CFLC preparation was not pure. Beside fibroblast-like cells several other cell types were present, among which endothelial cells. The latter cell type could easily be recognized due to its typical growth pattern (fig. $2.2 \mathrm{~b}$ ). On the order of $15-25 \%$ of the primary CFLC culture consisted of endothelial cells. The proportion of endothelial cells rapidly decreased during subcultivation. They were most likely overgrown by the fibroblast-like cells. After passage two, endothelial cells could no longer be seen in the CFLC preparation. The CFLC were larger than the CEC, formed a monolayer if confluent, while in the postconfluent state they showed a tendency to overgrow each other and had a more spindle-like appearance (fig. 2.2c). The CFLC reacted negatively to Von Willebrand Factor and endothelial cell antibody staining, and did not internalize Dil-Ac-LDL.

At the electron microscopic level the CEC and CFLC had a normal appearance, the CEC differed from the CFLC in the number of filaments and vesicles. CFLC contained more filaments and less pinocytotic vesicles than CEC (figs., $2.3 \mathrm{~b}$ and 2.3c). 

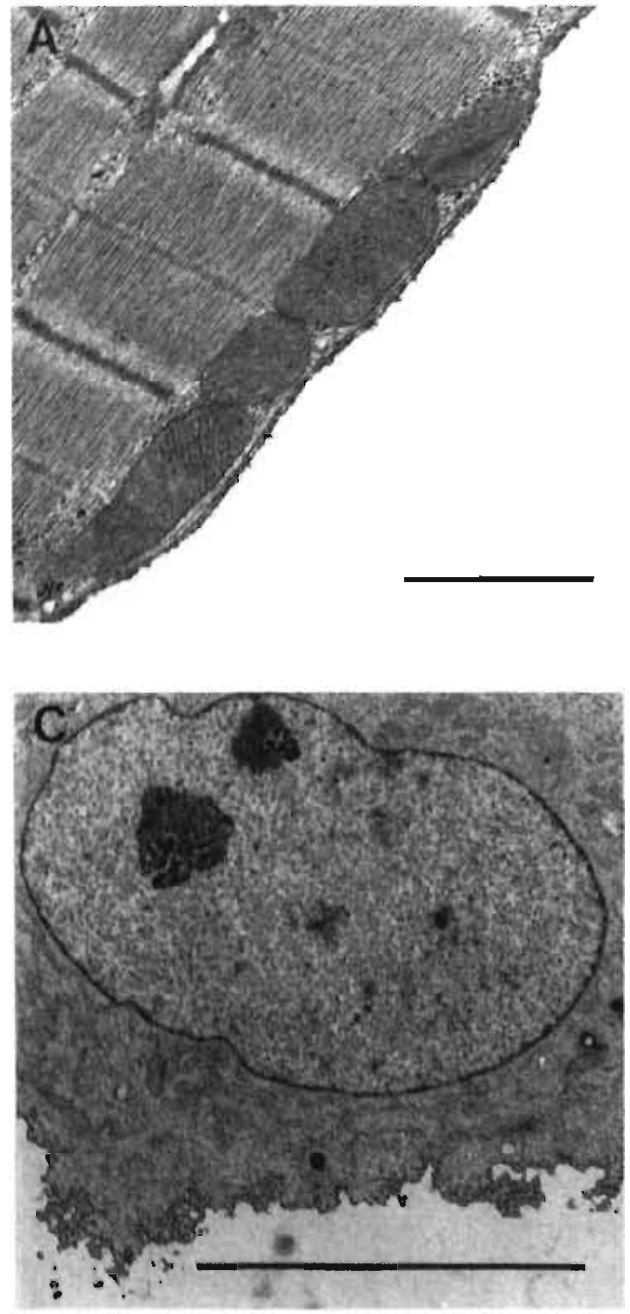

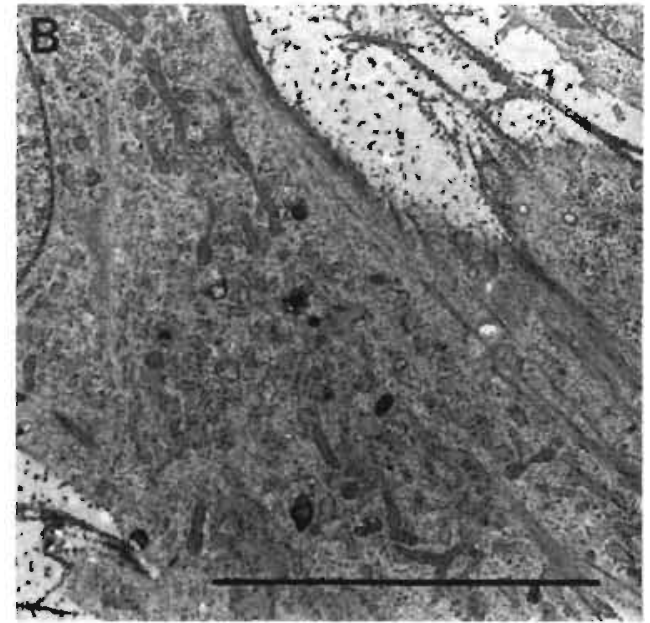

Figure 2.3. Transmission electron micrographs of cells isolated from adult rat heart.

A: section of a cardiomyocyte fixed with 50 $m M$ lysine and $2 \%$ glutaraldehyde, bar represents I $\mu \mathrm{m}$.

B: fibroblast-like cell fixed with $50 \mathrm{mM}$ lysine and $2 \%$ glutaraldehyde showing typical filamenis in cyloplasm, bar represents $10 \mu \mathrm{m}$. $C$ : endothelial cell fixed with $2 \%$ tannine and $2 \%$ glutaraldehyde resulting in a solid fixation of membranes and showing a multitude of vesicles in the vicinity of cell membrane. Bar represents $10 \mu \mathrm{m}$.

To identify the nature of CFLC, these cells were immunological tested for the presence of actin, desmin and vimentin (see table 2.1). They stained positively to vimentin and negatively to actin and desmin and behave in this way like fibroblasts. Incubation of CFLC with ascorbic acid $(50 \mu \mathrm{g} / \mathrm{ml})$ for three days caused an expression of actin and a down regulation of the expression of vimentin. 
Table 2.1. Staining of cardiac fibroblast-like cells (CFLC), isolated from adult rats, to several antibodies after control incubation or after stimulation with ascorbic acid $(50 \mu \mathrm{g} / \mathrm{ml})$ for three days.

\begin{tabular}{|c|c|c|}
\hline antibody & control & $\begin{array}{c}\text { ascorbic } \\
\text { acid }\end{array}$ \\
\hline vimentin & ++ & + \\
\hline desmin & - & - \\
\hline actin & - & + \\
\hline
\end{tabular}

: no staining, + : moderate staining, ++ : strong siaining.

\subsection{SUMMARY}

A reliable technique to isolate and subcultivate cardiomyocytes, endothelial cells and fibroblasts from adult rat heart is described. Cardiomyocytes were for more than $95 \%$ rod shaped and attached to dishes, no other cell types adhered to the dishes. The cells retained their morphology for some days when kept under the described culture conditions. The endothelial cells were pure and positively characterized by uptake of DiI-Ac-LDL and staining with VWF and RECA-1. They could be passaged till passage six. Fibroblast-like cells were identified as fibroblasts in their morphology, expression of intermediate filaments, presence of collagen, and could be kept in culture for more than 25 passages.

\subsection{REFERENCES}

1 Bruggeman, CA, Debie WHM, Muller AD, Schutte B, Van Dam-Mieras MCE (1988) Cytomegalovirus alters the Von Willebrand factor content in human endothelial cells. Thromb Haemost 59: 264.268

2 Cole OF, Fan T-P D, Lewis GP (1986) Isolation, Characterisation, growth and culture of endothelial cells from the rat aorta. Cell Biol Int Reports 10; 399-405

3 Diglio CA, Grammas P, Giacomelli F, Wiener J (1988) Rat heart-derived endothelial and smooth muscle cell cultures: isolation, cloning and characterization. Tissue Cell 20: 477.492

4 Dow JW, Harding NGL, Powell T (1981) Isolated cardiac myocytes I Preparation of adult myocytes and their homology with the intact tissue. Cardiovasc Res 15:483-514

5 Duijvestijn AM, van Goor H, Klatter F, Majoor GD, van Bussel E, van Breda Vriesman PJC (1992) Antibodies defining rat endothelial cells: RECA-1, a pan-endothelial cell-specific monoclonal antibody. Lab Invest 66: 459-466

6 Gimbrone MA Jr, Cotran RS, Folkman J (1974) Human vascular endothelial cells in culture. Growth and DNA synthesis. J Cell Biol 60: 673-684

7 Haworth RA, Goknur AB, Wamer TF, Berkhoff HA (1989) Some determinants of quality and yield in the isolation of adult heart cells from rat. Cell Calcium 10:57-82

8 Jacobson SL, Piper HM (1986) Cell Cultures of adult cardiomyocytes as models of the myocardium. J Mol Cell Cardiol 18: 661-678 
9 Jaffe EA, Nachman RL, Becker CG, Minick CR (1973) Culture of human endothelial cells derived from umbilical veins. Identification by morphological and immunological criteria. J Clin Invest 52: 2745-2756

10) Laurila P, Virtanen I, Wartiovaara J, Stanman S(1978) Fuorescent antibodies and lectins strain intracellular structures in fixed cells treated with nonionic detergent. J Histochem Cytochem 26: $251-257$

11 Maciag T, Cerundolo J, Ilsley S, Kelley PR, Forand R (1979) An endothelial cell growth factor from bovine hypothalamus: identification and partial characterization. Proc. Natl. Acad. Sci. USA 76: $5674-5678$

12 McGuire PG, Orkin RW (1987) Methods in laboratory investigation. Isolation of rat aortic endothelial cells by primary explant techniques and their phenotypic modulation by defined substrata. Lab Invest 57: 94-105

13 Merrilees MJ, Scott L (1981) Culture of rat and pig aortic endothelial cells. Differences in their isolation, growth ratc and glycosaminoglycan synthesis. A therosclerosis 38: 19-26

14 Nees S, Gerbes AL, Gerlach (1981) Isolation, identification, and continous culture of coronary cndothelial cells from guinea pig hearts. Eur J Cell Biol 24: 287-297

15 Piper HM, Probst I, Schwarty. P, Hutter FJ, Spieckermann PG (1982) Culturing of calcium stable adult cardiac myocytes. J Mol Cell Cardicl 14:397-412

16 Piper HM, Spahr R, Mertens S, Krlitzleldt A, Watanabe H (1990) Microvascular endothelial cclls from heart. In : Cell culture techniques in heart and vessel research. (ed HM Piper) Springer-Verlag, Berlin

17 Simionescu M, Simionescu N (1978) Isolation and characterization of endothelial cells from the heart microvasculature. Microvasc Res 16: 426-452

18 Voyta JC Via DP, Butterfield CE, Zetter BR (1984) Identification and isolation of endothelial cells based on their increased uptake of acetylated-low density lipoprotein. J Cell Biol 99: 2034-2040 


\section{CHAPTER 3}

\section{CONTINUOUS ENDOTHELIAL CELL LINES OBTAINED FROM RAT HEART}

Part of this chapter is published in

Linssen MCJG, Van Nieuwenhoven FA, Duijvestijn AM, (jlatz JFC, Van der Vusse GJ (1993) Continuous endothelial cell lines from adult rat heart. In Vitro Cell Dev Biol 29A: 611-613. 


\subsection{INTRODUCTION}

As a barrier between blood and interstitial space, endothelial cells (EC) play a prominent role in the blood-tissue exchange of molecules (17). Besides, EC can synthesize physiologically important compounds, such as vasoactive and antithrombogenic agents, and secrete them to the blood and/or to the subendothelial matrix (9).

To investigate endothelial cell physiology in more detail, cultured cells are increasingly used in a variety of experimental models. Inspite of numerous attempts only few investigators have succeeded in isolating and culturing endothelial cells from rat heart $(2,7,18)$. The main problem to be solved is the presence of contaminating non-endothelial cells which easily overgrow the endothelial cells in culture and, hence, influence the outcome of the experiments. In our laboratory a technique has been implemented to isolate and cultivate cardiac EC (CEC), cardiomyocytes (CMC) and fibroblast-like cells (CFLC) from adult rat heart $(13,14$, and chapter 2$)$. Because of the relative low yield and the limiled life-span of the cultured CEC, extensive studies on the (patho)physiological properties of CEC were found to be seriously hampered. For that reason attempts were made to obtain continuous cell lines originating from the rat CEC cultures.

The presence of a spontaneously transformed and immortalized line of human umbilical vein endothelial cells (HUVEC) has been described (19), but to our best knowledge a rat heart EC line has not yet been reported so far. In this chapter the establishment of two continuous cell lines of CEC cultures isolated from adult rat is described, designated rat heart endothelial cell line-50 (RHEC-50) and RHEC116. These CEC lines show characteristics similar to both freshly isolated CEC and CEC in vivo. The RHEC-50 and RHEC-116 will be useful to study cardiovascular physiology.

\subsection{METHODS}

\section{Isolation of cells}

CEC were isolated from adult rat heart as described in chapter 2. Briefly, hearts were removed from 12 weeks old male Wistar or Lewis rats under ether anaesthesia, and perfused for 30 min with a modified Krebs Ringer buffer solution (MKR) containing: $115 \mathrm{mM} \mathrm{NaCl}, 2.6 \mathrm{mM} \mathrm{KCl}, 1.2 \mathrm{mM} \mathrm{KH}_{2} \mathrm{PO}_{4}, 1.2$ $\mathrm{mM} \mathrm{MgSO}, 10 \mathrm{mM} \mathrm{NaHCO}, 10 \mathrm{mM} \mathrm{N}$-2-hydroxyethylpiperazine-N'-2ethanesulfonic acid (HEPES), $11 \mathrm{mM}$ glucose, $4 \mathrm{mM}$ taurine, $25 \mu \mathrm{M} \mathrm{CaCl}_{2}$ and $0.06 \%$ collagenase; $\mathrm{pH}$ was set at 7.4 and the buffer solution was gased with $95 \%$ $\mathrm{O}_{2}$ plus $5 \% \mathrm{CO}_{2}$. Thereafter the EC of one heart were collected and plated on two, fibronectin-precoated Falcon tissue culture dishes of $3.5 \mathrm{~cm}$ diameter in EC culture medium. The latter medium consisted of $40 \%$ M199, 40\% RPMI1640, 
$20 \%$ fetal calf serum (FCS), and supplemented with $2 \mathrm{mM} \mathrm{L}$-glutamine, $13 \mathrm{mM}$ $\mathrm{NaHCO}_{3}, 10 \mathrm{mM}$ HEPES, $50 \mu \mathrm{g} / \mathrm{ml}$ gentamicin, $20 \mathrm{U} / \mathrm{ml}$ heparin sodium, approximately $40 \mu \mathrm{g} / \mathrm{ml}$ bovine brain extract and $2.5 \mu \mathrm{g} / \mathrm{ml}$ fungizone. The primary cultures were provided with fresh culture medium every day. When almost confluent, the CEC clones were washed once with phosphate buffered saline (PBS), trypsinized with PBS containing $0.67 \mathrm{mM}$ ethylenediaminetetraacetate (EDTA) and $1.25 \mathrm{mg} / \mathrm{ml}$ trypsin to detach the cells, and subsequently plated on culture dishes in a split ratio of 1 to 3 in EC culture medium without fungizone (passage one). Thereafter, the cells were further cultured, usually up to passage 6 . However, occasionally ( 2 out of 60 successful isolation procedures) some batches grew also beyond passage 6 . These cells could be plated in a split ratio of at least 1 to 6 .

Cells were screened for mycoplasma contamination by the Department of Medical Microbiology and by the Centralised Experimental Animal Facilities, University of Limburg, Maastricht, The Netherlands, using generally accepted standard techniques (1).

\section{Characterization of endothelial cells}

The CEC were tested for uptake of 1, ''-dioctodecyl-1-3,3,3',3'-tetramethylindocarbocyanine-perchlorate-acetylated low density lipoprotein (Dil-Ac-LDL). To this end, cells cultivated on 96 well plates and 50-75\% confluent, were incubated with $10 \mu \mathrm{g}$ Dil-Ac-LDL/ml culture medium at $37^{\circ} \mathrm{C}$ for four hours. The medium was washed away and the cells were studied with the use of a Zeiss fluorescence microscope equipped with appropriate barrier filters. For immunofluorescence microscopy cells on 96 well plates were fixed in $3 \%$ paraformaldehyde in PBS and treated with $0.05 \%$ Nonidet P40 in PBS to permeabilize the membranes. After four times washing with PBS, cells were incubated with rabbit anti-human-Von Willebrand Factor (VWF), diluted 1:100 in PBS containing $1 \%$ bovine serum albumin (BSA V) and $0.1 \% \mathrm{NaN}_{3}$ in a humidified atmosphere at $37^{\circ} \mathrm{C}$ for $30 \mathrm{~min}$, or incubated with RECA-1 (a rat endothelial cell antibody; ref. 3), diluted 1:500 in PBS containing 1\% BSA plus $0.1 \% \mathrm{NaN}_{3}$ at $37^{\circ} \mathrm{C}$ for $30 \mathrm{~min}$. Alternatively the cells were incubated with antivimentin, anti-cytokeratins or anti-desmin under the same conditions. After washing with PBS, cells were incubated with fluorescein isothiocyanate (FITC). conjugated swine anti-rabbit-IgG or FITC-conjugated rabbit anti-mouse-Ig(i. The cells were washed and mounted in glycin buffered glycerol ( $\mathrm{pH}$ 8.6) for microscopic evaluation.

For quantitative analysis cells were grown to confluency on $75 \mathrm{~cm}^{2}$ tissue culture flasks. Photographs from the cells were taken with a Zeiss inverted phase contrast microscope, whereupon the cells were harvested by trypsinization. Cell protein content was determined according to Lowry and colleagues (1.5) and DNA was measured with the Hoechst 33258 dye as described by Labarca and Paigen (11). 

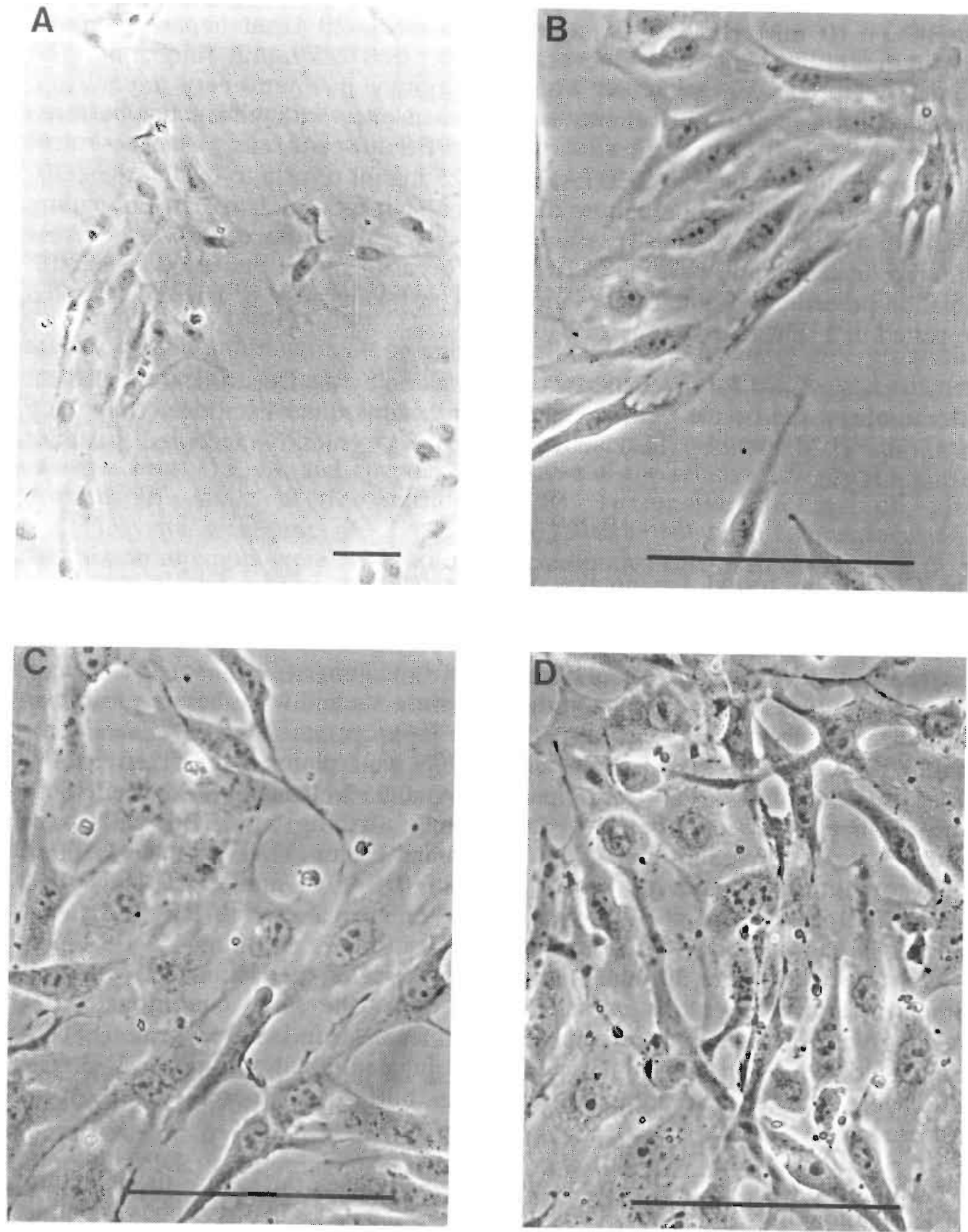

Figure 3.1. Phase-contrast photographs of rat cardiac endothelial cells (CEC). A: passage 3 of a representative primary culture of freshly isolated CEC. B: rat heart endothelial cell line-50 (RHEC. 50) passage 28. C: RHEC-50 passage 101. D: RHEC-116 passage 121. Bar represents $0.1 \mathrm{~mm}$. 
Karyotyping of cells was performed by routine procedures at the Department of Clinical Genetics, University of Limburg, Maastricht, The Netherlands. To this end, subconfluent cells were harvested by trypsinization, incubated with colcemid, fixed with acetic acid/methanol (1:3), and spotted on microscope slides.

Expression of membrane determinants was monitored after stimulation with interferon- $\gamma($ IFN $-\gamma)$. Fresh culture medium containing $100 \mathrm{U} / \mathrm{ml} \mathrm{IFN}-\gamma$ was applied to confluent EC-monolayers on 96 well plates. Incubation occurred for 3 days. Subsequently cells were washed with washing medium (RPMI1640 containing $10 \% \mathrm{FCS}$ and $20 \mathrm{mM}$ HEPES) and incubated with monoclonal antibodies OX-6 (anti-MHC class II), OX-18 (anti-MHC class I), and 1A29 (antiICAM-1). After 1 hour of incubation at room temperature cells were washed 3 times with washing medium and incubated with FITC conjugated goat anti-mouse $\mathrm{F}(\mathrm{ab})_{2}$ IgG for $30 \mathrm{~min}$. After washing, the cells were fixed in $1 \%$ paraformaldehyde in PBS and examined by fluorescence microscopy.

\section{Materials}

Unless otherwise stated, all chemicals were obtained from Merck (Darmstadt, FRG) and were of the highest purity available. Collagenase CLS, batch 67047M, was purchased from Cooper Biomedical Worthington (Malvern, PA USA), fibronectin and anti-VWF from the Central Laboratory of the Netherlands Red Cross Transfusion Service (CLB, Amsterdam, The Netherlands), M199, RPMI1640, trypsin and fungizone from Gibco (Life Technologies Ltd., Paisley, Scotland UK) FCS; batch 701064 from Sera-Lab Ltd., Crawley Down, UK, or batch 0135827 from Flow Laboratories Ltd., Irvine, Scotland UK, or batch 40G3700P from Gibco). L-glutamine was obtained from Sigma Chemical Co. (St. Louis, MO USA), heparin sodium from Serva GmbH (Heidelberg, FRG), DiI-AcLDL from Biomedical Technologies Inc. (Stoughton, MA USA) Falcon tissue culture dishes were purchased from Becton Dickinson Ltd. (Playmouth, UK) and microtiter plates and culture flasks from Costar Corp. (Cambridge, MA USA), FITC-conjugated swine anti-rabbit-IgG and FITC-conjugated rabbit anti-mouse IgG from Dakopatts (Copenhagen, Denmark), FITC-conjugated goat anti-mouse $\mathrm{F}(\mathrm{ab})_{2}$ IgG from Cappel Lab. Inc. (Cochranville, PA USA). IFN- $\gamma$ was kindly donated by Dr. P. van der Meide, OX-6 and OX-18 were obtained from the European Collection of Animal Cell Cultures (ECACC, Salisbury, UK), 1 A29 was kindly donated by Dr. M. Miyasaka (ref. 20). Anti-vimentin (RV202), antidesmin (RD301) and anti-cytokeratins (RGE53, RCK102, M20, RCK105, LP2K) were generously provided by Prof. Dr. F. Ramaekers. BSA V was obtained from Boehringer Mannheim GmbH (Mannheim, FRG). 


\subsection{RESULTS AND DISCUSSION}

\section{Establishment of the endothelial cell lines}

In our routine procedure for isolating CEC from adult rat $(13,14)$, the CEC obtained from one heart are essentially pure but few in number $\left(10^{2}-10^{3}\right)$. Therefore, the cells usually are plated on about $20 \mathrm{~cm}^{2}$ culture dishes. It takes on the average 10 days for these cultures to reach the stage of confluency. In primary culture, the CEC have a typical clonal form of growing, but after the first passage, they form a more homogeneous monolayer with elongated cells. Till passage three or four there are no changes in cell morphology. Usually, between passage four and six CEC have reached their proliferative life-span, the cells don't divide anymore and start to senesce. This process is accompanied by large increases in cell area, cell volume and protein content (16).

In attempts to obtain continuously dividing cells, the CEC in senescent condition were kept in culture. Two out of 60 successful CEC isolations showed an atypical growth pattern after passage six. These cell lines, RHEC-50 isolated from a 14 week-old Wistar rat and RHEC-116 isolated from a 13 week-old Lewis rat, showed initially the following growth pattern. Plated cells hardly grew after passage six for about two weeks. Thereafter some cells started to divide and formed a confluent monolayer again. The cells could be passaged, and in the subsequent 12 months more than 100 passages have been achieved. Figure 3.1 shows light micrographs of RHEC-50 and RHEC-116 and, for comparison, passage three of a representative primary CEC culture. There is a morphological difference in cell size; RHEC-50 and RHEC-116 are markedly smaller than the CEC of passage three.

The growth characteristics of the cell lines have been determined. The protein contents of the RHEC-50 and RHEC- 116 were about 50 pg per cell based on counting cell numbers on photographs of the tissue culture flasks made just before trypsinization. The DNA contents of the cell lines were on the average $4.5 \mathrm{pg}$ per cell when based on cell counting of the photographs. This value is in the same range as reported earlier (21). RHEC-50 and RHEC-116 each showed a constant protein/DNA ratio of about 10 . For young passages of a representative primary CEC culture, this ratio was found to be higher and increased with passage number, being 25,33 and 43 at passages one, two and three, respectively. These findings are in agreement with the morphological observation of difference in cell size between the continuous cell lines and the passages one to six of primary CEC.

The RHEC-50 and RHEC-116 were routinely subcultivated in a split ratio of 1 to 6 and grew to confluency within two to three days. In this time one $10 \mathrm{~cm}$ diameter dish gave a yield of about $7.10^{6}$ cells (ca. $350 \mu \mathrm{g}$ protein). The omission of growth factor/ heparin or fibronectin precoating of the culture dishes reduced the proliferative rate by $50-60 \%$. Reduction of the percentage FCS from $20 \%$ to $10 \%$ also diminished the growth rate markedly. 


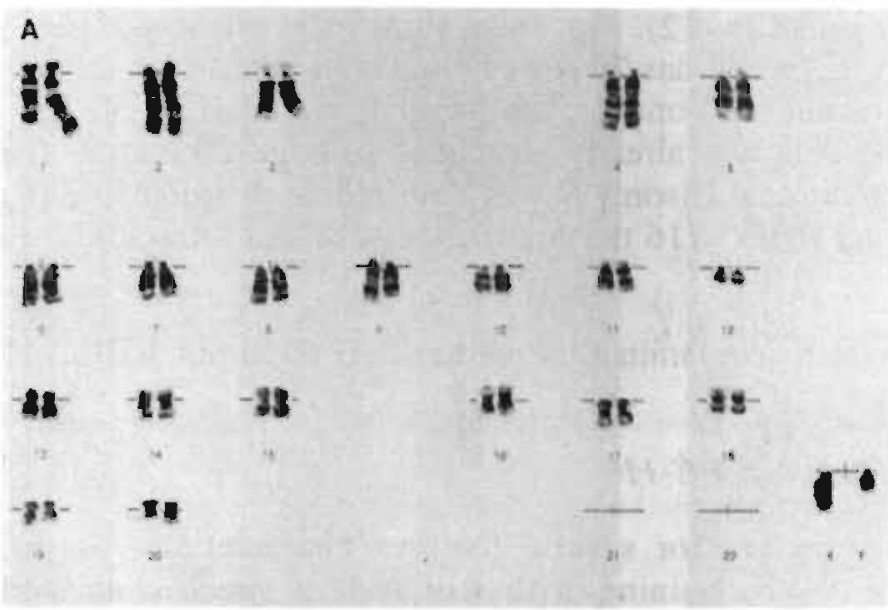

Figure 3.2. Karyolypes after Giemsa staining of rat heart endothelial cell lines A: RHEC-110 passage 113. B: RHEC-50 passage 20. C: RHEC-50 passage 93.

B

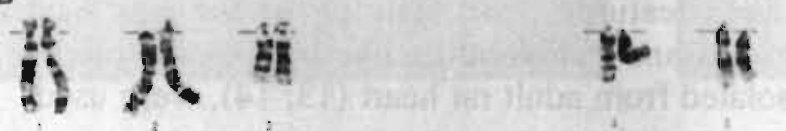

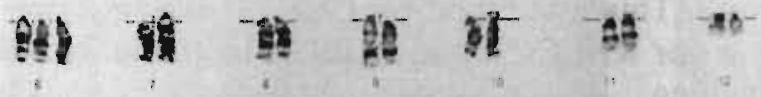

$-85-15-83-38-88-74$
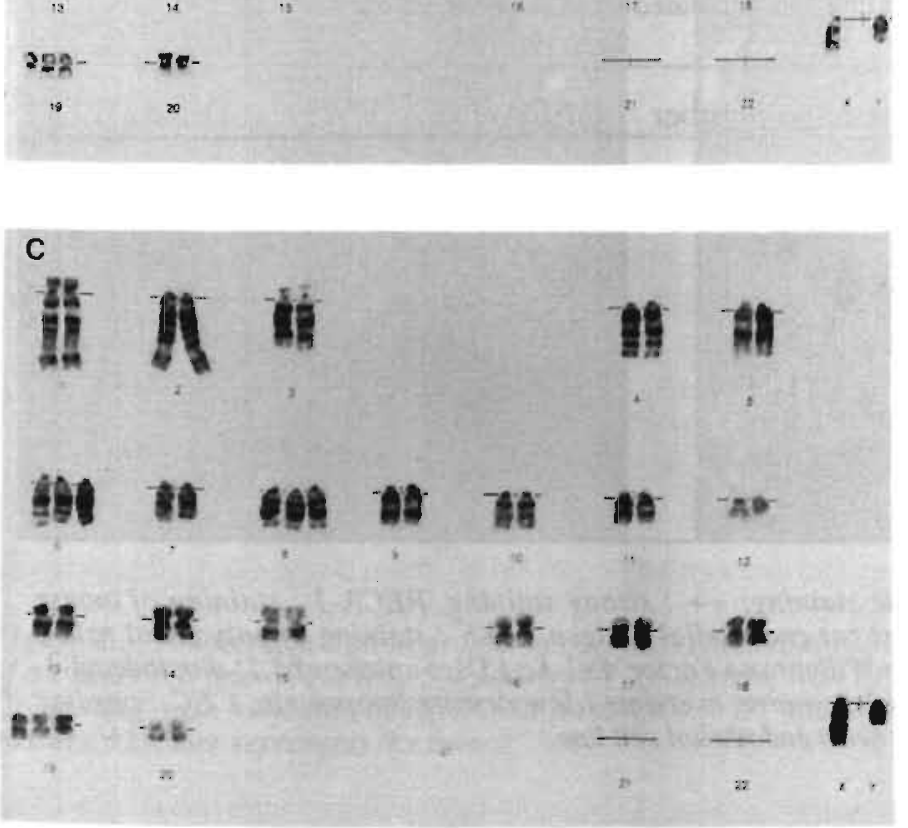
The karyotype of the RHEC-116 had a modal number of 42 chromosomes which is the regular number for rat cells (12). Fig. 3.2a shows the chromosomes of RHEC-116 at passage 113. Each cell has 20 pairs of autosomes and each one of a $\mathrm{X}$ and one of a $\mathrm{Y}$ chromosome. In contrast, the population of RHEC-50 has a trisomy 6 and trisomy 19. This was already present at passage 20 and 59 (fig. 3.2b). At passage 93 an additional trisomy 8 was detected in this cell line (fig. $3.2 \mathrm{c}$ ). In both RHEC-50 and RHEC-116 the occurrence of tri- or tetraploidy was found to be less than $10 \%$.

When screened for mycoplasma contamination neither RHEC-50 nor RHEC-116 showed a positive reaction.

\section{Characteristics of RHEC-50 and RHEC-116}

The cell lines have been checked for several features characteristic for EC, including the presence of VWF, staining with RECA-1, a specific antibody directed against endothelial cell surface antigen (3), and internalization of Dil-AcLDL. In addition, RHEC lines were compared to young passages of primary cultures of CEC for the examined features. Also staining to the intermediate filament proteins vimentin, desmin and cytokeratins has been performed. For negative controls CFLC, also isolated from adult rat heart $(13,14)$, were used.

The VWF staining was not homogeneous; some cells showed a higher VWF content than others in the same well. This was found for CEC of passages one to four of primary cultures as well as for RHEC-50 and RHEC-116 (table 3.1, fig. 3.3). CFLC did not show VWF staining.

Table 3.1. Characteristics of cell types isolated from adult rat heart.

\begin{tabular}{lcccc}
\hline cell type & passage number & RECA-1 & VWF & Dil-Ac-LDL \\
\hline RHEC-50 & 12 & + & + & ++ \\
RHEC-50 & 87 & + & + & ++ \\
RHEC-116 & 8 & + & + & ++ \\
RHEC-116 & 103 & + & + & ++ \\
freshly isolated CEC & 3 & + & + & ++ \\
fibroblast-like cells & 20 & - & - & - \\
\hline
\end{tabular}

- no staining. + : moderate slaining, ++ : strong staining, RECA-l : staining of mouse monoclomal antibody against rat endothelial antigen, $V W F$ : staining of polyclonal rabbit anribody against human Von Willebrand Factor, DiI-AC-LDL : uptake of 1,I'-dioctodecyl-1$3,3,3$ ' $3^{\prime}$-letramethyl-indocarbocyanine-acetylated low density lipoprotein, CEC : cardiac endothelial cells, RHEC: rat heart endothelial cell line. 

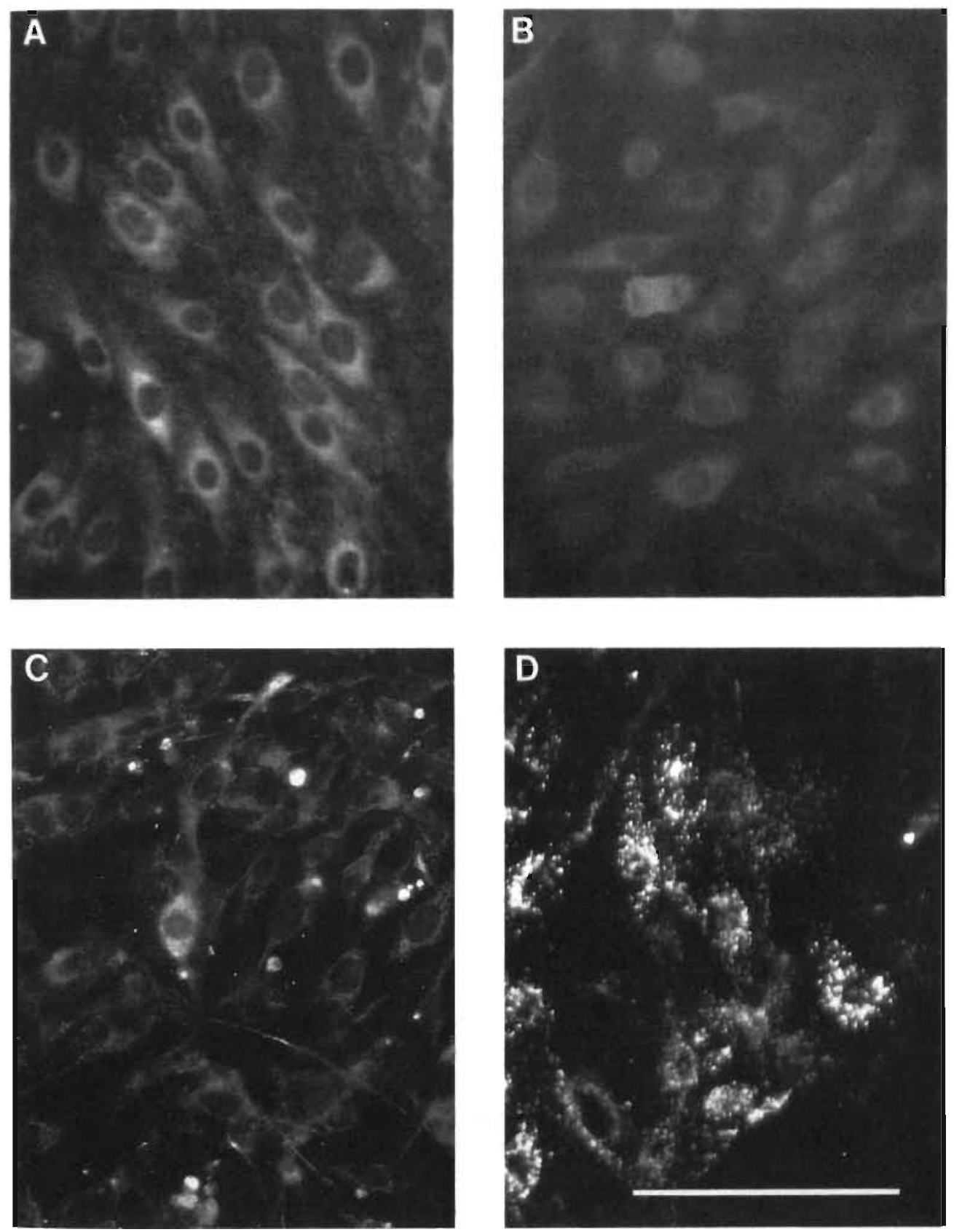

Figure 3.3. Fluorescence photographs of cardiac endothelial cells (CEC). A: staining with VWF of rat heart cell line-50 (RHEC-50) passage 87. B: staining with RECA-1 of RHEC-50 passage 87. C: staining with vimentin of RHEC-50 passage 43. D: uplake of Dil-AC-LDL of RHEC- 116 passage 121. Bar represents $0.1 \mathrm{~mm}$. 
RECA-1 reacted weakly but clearly with RHEC-50, RHEC-116 and with passages one to four of primary CEC cultures (table 3.1), whereas CFLC did not react.

Vimentin is the intermediate filament protein of cells derived from the mesenchym, and is generally thought to be the only intermediate filament protein that is expressed by endothelial cells (7). However, co-expression of vimentin and cytokeratins (10), or vimentin and desmin (6) in EC have been reported. The RHEC-50 and the RHEC-116, as well as the CFLC stained positive for vimentin (fig. 3.3c) and negative for desmin and most cytokeratins tested. Only RHEC-50 reacted weakly positive to one cytokeratin antibody (LP2K).

The Dil-Ac-LDL uptake by the EC was very distinct from that of the CFLC. At various passages RHEC-50 and RHEC-116 were clearly positive and showed a staining intensity similar to that of passages one to four or primary culture of representative CEC (table 3.1, fig. 3.3).

Because the expression of membrane determinants is well studied in HUVEC (4) and neonatal rat heart EC (5), this feature was also investigated in the present cell lines. Both RHEC-50 and RHEC-116 demonstrated no expression of class II major histocompatibility (MHC) antigen, a distinct expression of class I MHC antigen, and a weak expression of the adhesion molecule ICAM-1 (table 3.2).

Table 3.2. Expression of membrane determinants by the rat heart endothelial cell lines (RHEC-50 and RHEC-116), before and after stimulation with interferon- $\gamma$.

\begin{tabular}{|c|c|c|c|c|}
\hline $\begin{array}{c}\text { membrane } \\
\text { determinants }\end{array}$ & $\begin{array}{l}\text { RHEC-50 } \\
\text { no IFN- } \gamma\end{array}$ & $\begin{array}{l}\text { RHEC-50 } \\
\text { with IFN- } \gamma\end{array}$ & $\begin{array}{l}\text { RHEC-116 } \\
\text { no IFN- } \gamma\end{array}$ & $\begin{array}{l}\text { RHEC-116 } \\
\text { with IFN-y }\end{array}$ \\
\hline class II MHC & - & ++ & - & + \\
\hline class I MHC & + & ++ & + & ++ \\
\hline ICAM-1 & \pm & ++ & \pm & + \\
\hline
\end{tabular}

MHC : major histocompatibility complex, ICAM : intercellular adhesion molecule. Confluent cultures were stimulated with $100 \mathrm{U} / \mathrm{ml}$ interferon-y (IFN-y) for 3 days. Expression was measured by immunofluorescence, - : negative, \pm : weakly positive, + : positive, ++ : strongly positive.

Stimulation of the cell lines with $100 \mathrm{U} / \mathrm{ml}$ IFN- $\gamma$ for 3 days induced expression of MHC class II molecules and upregulation of MHC class I and ICAM-1 antigens. Induction and upregulation of MHC class 11 and ICAM-l antigens, respectively, was stronger in RHEC-50 than in RHEC-116. In general, the expression and induction patterns of the tested antigens in the cell lines were comparable with passages one to four of primary cultures of isolated CEC. These observations are 
in agreement with earlier findings in human and rat EC (4. 5) and underline the endothelial properties of the RHEC-50 and RHEC-116.

\section{Application of RHEC-50 and RHEC-116}

At present, the continuous cell lines originating from EC of adult rat heart are successfully used in a variety of studies in our laboratory. The transport characteristics of glucose across endothelial preparations grown on inserts with porous membranes are currently investigated. Because the continuous cell lines offer the possibility to generate appreciable amounts of EC mRNA and protein. these cell preparations are also employed in molecular biological studies on the intracellular transport of fatty acids and the role of fatty acid-binding protein (FABP) therein. Finally, the continuous cell lines represent powerful tools for transfection studies aiming at overexpression of cellular proteins in order to explore the specific effects of these macromolecules in EC function.

\subsection{SUMMARY}

The described continuous CEC lines have shown to possess the same characteristics of CEC (presence of VWF, uptake of Dil-Ac-LDL, staining of RECA-1, vimentin and upregulation of membrane determinants after stimulation with IFN- $\gamma$ ) as primary cultures of freshly isolated CEC and EC in situ. These characteristics were preserved for at least more than 100 passages. Moreover, the cell lines retained a constant behaviour in growth and could yield a large number of cells (from $1.10^{6}$ to $7.10^{6}$ cells in two days). Therefore, both RHEC-50 and RHEC-116 are suitable for experimental studies.

\section{Acknowledgements}

The authors thank Frank Kornips from the Department of Clinical Genetics, Academic Hospital Maastricht, for the karyotypic analysis, Jacqueline Maes from Centralised Experimental Animal Facilities, University of Limburg and Selma Herngreen from the Department of Medical Microbiology for the mycoplasma screening, Peter Dormans from the Department of Medical Microbiology for taking photographs and Gauillaume van Eys from the Department of Molecular Cell Biology for the staining of the intermediate filaments.

\subsection{REFERENCES}

1 Chen TR (1977) In situ detection of mycoplasma contamination in cell cultures by fluorcscent Hoechst 33258 stain. Exp Cell Res 104: 255-262

2 Diglio CA, Grammas P, Giacomelli F, Wiener J (1988) Rat heart-derived endothelial and smooth muscle cell cultures: isolation, cloning and characterization. Tissuc Cell $20.477-492$ 
3 Duijvestijn AM, van Goor $\mathrm{H}$, Klatter F, Majoor GD, van Bussel E, van Breda Vriesman PJC (1992) Antibodies defining rat endothelial cells: RECA-1, a pan-endothelial cell-specilic monoclonal antibody. Lab Invest $66: 459-466$

4 Dustin ML, Rothlein R, Bhan AK, Dinarello CA, Springer T.A (1986) Induction by IL- I and interferon, tissue distribution, biochemistry, and function of a natural adherence molecule (ICAM-1). J Immunol 137: 245-254

5 Ferry B, Halttunen J, Leszczynski D. Schellekens H, van der Meide PH, Hayry P (1987) Impact of class Il major histocompatibility complex antigen expression on the immunogenic potential of isolated rat vascular cndothelial cells. Transplantation 44: 499-503

6 Fujimoto T, Singer S (1986) Immunocytochemical studies of endothelial cells in vivo. T The presence of desmin only, or desmin plus vimentin, or vimentin only in endothelial cells of different capillaries of the adult chicken. J Cell Biol 103: 2775-2786

7 Franke WW, Schmid E, Winter S, Osborn M, Weber K (1979) Widespread occurrence of intermediate-sized filaments of the vimentin-type in cultured cells from diverse vertebrates. Exp Cell Res 123: $25-46$

8 Gerritsen ME, Cheli CD (1983) A rachidonic acid and prostaglandin endoperoxide metabolism in isolated rabbit and coronary microvessels and isolated and cultivated coronary endothelial cells. J Clin Invest 72: 1658-1671

9 Jaffe EA (1987) Cell biology of cndothelial cells. Hum Pathol 18: 234239

10 Jahn L, Fouquet B, Rohe K. Franke WW (1987) Cytokeratins in certain endothelial and smooth musele cells of two taxonomically distant vertebrate species, Xenopus leavis and man. Differentiation 36: 234-254

1) Labarca C. Paigen K (1980) A simple, rapid, and sensitive DNA assay procedure. Anal Biochem 102: 344352

12 Levan G (1974) Nomenclature for G-bands in rat chromosomes. Hereditas 77: 37-52

13 Linssen MCJG, Engels W, Lemmens PJMR, Heijnen VVTh, Van Bilsen M, Reneman RS, Van der Vusse GJ (1993) Production of arachidonic acid metabolites in adult rat cardiac myocytes, endothelial cells and fibroblast-like cells. Am J Physiol 264: H973-H982

14 Linssen MCJG, Vork MM, De Jong YF, Glatz. JFC, Van der Vusse GJ (1990) Fatty acid oxidation capacity and fatty acid-binding protein content of different cell types isolated from rat heart. Mol Cell Biochem 98: 19-25

15 Lowry O,Rosebrough NJ, Farr AL, Randall RJ (1951) Protein measurement with the folin phenol reagent. J Biol Chem 193: 265-275

16 Rosen EM, Mucller SN, Noveral JP, Levine EM (1981) Proliferative characteristics of clonal endothelial cell strains. J Cell Physiol 107: 123-137

17 Simionescu M, Simionescu N (1986) Functions of the endothelial cell surface. Ann Rev Physiol 48: 279.293

18 Spühr R, Krutafeldt A, Mertens S, Siegmund B. Piper HM (1989) Fatty acids are not an important fucl for coronary microvascular endothelial cells. Mol Cell Biochem 88: 59-64

19 Takahashi K, Sawasaki Y, Hata J-I, Mukai K, Goto T (1990) Spontaneous transformation and immortalization of human endothelial cells. In Vitro Cell Dev Biol 25: 265-274

20 Tamati T. Miyasaka M (1990) Identification of monoclonal antibodies reactive with the rat homolog of ICAM- 1 and evidence for a differential involvement of ICAM-1 in the adherence of resting versus activated lymphocytes to high endothelial cells. Int Immunol 2: 165-171

21. Van der Laarse A, Hollaar L. Van der Valk EJM, Hamers S (1989) A method to quantitate cellnumbers of muscle cells and non-muscle cells in homogenised heart cell cultures. Cardiovase Res 23: $928-933$ 
CHAPTER 4

FATTY ACID OXIDATION CAPACITY AND FATTY ACID-BINDING PROTEIN CONTENT OF DIFFERENT CELL TYPES ISOLATED FROM RAT HEAR'T

This chapter is published in

Linssen MCJG, Vork MM, De Jong YF, Glatz JFC, Van der Vusse GJ (1990) Fatty acid oxidation capacity and fatty acid-binding protein content of different cell types isolated from rat heart. Mol Cell Biochem 98: 19-25. 


\subsection{INTRODUCTION}

Although the heart can utilize a variety of substrates to fulfill its energy demands, fatty acids are preferred under nomal conditions (11). Since de novo synthesis of fatty acids in cardiomyocytes is limited, these substances are mainly derived from exogenous sources, including fatty acids bound to albumin in the vascular compartment. In the heart cardiomyocytes are considered to be the principal group of fatty acid consuming cells, although coronary endothelial cells are also capable of fatty acid oxidation (12).

The exact mechanism underlying the transport of fatty acids from the vascular compartment to the mitochondrial site of consumption in the cardiomyocytes is incompletely understood (2). It has been hypothetized that fatty acids cross the endothelial cells, lining the microvasculature, through the luminal cell membrane, the endothelial cytoplasm and the abluminal cell membrane, then diffuse through the interstitial space towards the myocytal membrane (sarcolemma), and cross the sarcolemma and the cytoplasm of the myocyte to finally reach the mitochondrial outer membrane, where conversion of the fatty acyl moiety into acylCoA occurs $(13,15)$.

Fatty acid-binding proteins (FABPs) are thought to be involved in both the transendothelial and the intramyocytal transport of fatty acids $(2,14,15)$. The FABPs belong to a family of relatively low molecular weight proteins, are abundantly present in most cell types and show a high affinity for long-chain fatty acids (1). Recently it has been shown that the fatty acid-oxidizing capacities of several tissues run in parallel with their FABP contents (7).

The FABP type present in the cytosolic fraction of homogenized rat hearts $(\mathrm{H}$ $\left.F A B P_{c}\right)$ has been extensively characterized and quantified $(4,6)$. Information on the cellular distribution of $\mathrm{H}-\mathrm{FABP}_{\mathrm{c}}$ in the heart is scanty. Immunocytochemical studies have shown that bovine and rat cardiomyocytes contain $\mathrm{H}-\mathrm{FABP}_{\mathrm{c}}(3,5)$, whereas considerable staining was also observed in rat cardiac endothelial cells in situ (5). However, reliable quantitative data are lacking.

The present study was conducted to quantify $\mathrm{H}-\mathrm{FABP}_{\mathrm{c}}$ in various cell types isolated from adult rat heart, including cardiomyocyles, endothelial cells and fibroblast-like cells. The content of $\mathrm{H}-F A B P_{c}$ was related to the capacity to oxidize fatty acids by these particular cardiac cell types.

\subsection{METHODS}

Isolation and cultivation of cells

Cardiomyocytes (CMC), cardiac endothelial cells (CEC) and fibroblast-like cells (CFLC) were isolated, as described in chapter 2. 


\section{Experimental conditions and assay techniques}

Cultured CEC and CFLC between passage two and six, and primary CMC were washed three times with prewarmed Hanks' Balanced Salt Solution (HBSS) containing: $137 \mathrm{mM} \mathrm{NaCl}, 5.4 \mathrm{mM} \mathrm{KCl}, 1.3 \mathrm{mM} \mathrm{CaCl} 2.2 \mathrm{H}_{2} \mathrm{O}, 0.9 \mathrm{mM}$ $\mathrm{MgSO}_{4} .7 \mathrm{H}_{2} \mathrm{O}, 0.4 \mathrm{mM} \mathrm{Na} \mathrm{HPO}_{4}, 5 \mathrm{mM}$ glucose, $10 \mathrm{mM}$ HEPES and $4.1 \mathrm{mM}$ $\mathrm{NaHCO}_{3}: \mathrm{pH} 7.4$. Cells (approximately $1 \mathrm{mg}$ protein in $300 \mu \mathrm{l}$ HBSS per dish) were scraped from the dishes with a rubber policeman and subsequently homogenized. The homogenization fluid contained $250 \mathrm{mM}$ sucrose and $1 \mathrm{mM}$ EDTA. This suspension was homogenized in a Potter-Elvehjem homogenizer, using successive pestle clearances of 0.1 and $0.05 \mathrm{~mm}$.

The oxidation of $120 \mu \mathrm{M}[1-14 \mathrm{C}$ palmitate bound to albumin (molar ratio 5:1) was measured at $37^{\circ} \mathrm{C}$ for 30 minutes with 0.2 to $0.3 \mathrm{mg}$ cellular protein per incubation. Oxidation rates were calculated from the radioactivity of the formed ${ }^{14} \mathrm{CO}_{2}$ and ${ }^{14} \mathrm{C}$-labeled acid-soluble intermediates as described by Glatz et al. (8). Protein content was determined by the method of Lowry et al. (10). Cytochrome $\mathrm{C}$ oxidase activity of the homogenates was measured at $25^{\circ} \mathrm{C}$ as described before (9).

The $\mathrm{H}-\mathrm{FAPB}_{\mathrm{c}}$ content in the different cell homogenates was measured by enzymelinked immunosorbent assay (ELISA) using polyclonal rabbit antibodies raised against rat $\mathrm{H}-\mathrm{FABP}_{\mathrm{c}}$. After centrifugation $(10,000 \mathrm{~g}, 5 \mathrm{~min})$ of the homogenates, the supernatants were directly coated to PVC microtiterplates and quantified by comparing them with a series of $\mathrm{H}-\mathrm{FABP}_{\mathrm{c}}$ standards in a concentration range of 2 to $20 \mu \mathrm{g} / \mathrm{l}$. After incubation with anti-H-FABP ${ }_{\mathrm{c}}$ antibodies and goat anti rabbit$\mathrm{IgG} / \mathrm{HRPO}$, the oxidation rate of o-phenylenediamine was monitored in a Flow Multiscan plus MKII.

\section{Materials}

Unless otherwise stated, all chemicals were obtained from Merck (Darmstadt, FRG). The culture media RPMI1640, M199 and the trypsin solution were purchased from Flow (Irvine, Scotland UK), FCS from Boehringer Mannheim GmbH (Mannheim, FRG) and Seralab Ltd. (Crawley Down, UK) BSA V from Boehringer Mannheim GmbH. The Falcon tissue culture dishes and microtiter plates were obtained from Becton Dickinson Ltd (Playmouth, UK). Goat anti rabbit/HRPO was obtained from Nordic (Tilburg, the Netherlands), [1 ${ }^{14} \mathrm{C}$ ]palmitate $(50-60 \mathrm{mCi} / \mathrm{mmol})$ from Amersham International (Buckinghamshire, UK).

\subsection{RESULTS}

The cardiomyocytes used in this study were kept in culture during four hours after isolation. They were mechanically at rest. Microscopic evaluation showed that over $95 \%$ of the cells were rod-shaped. The CEC were grown to confluency. 
The CFLC preparation, at passage two or higher lacked endothelial cells. CFLC formed a monolayer if confluent; in the post-confluent state they overgrew each other and had a more spindle-like appearance.

Palmitate oxidation was measured radiochemically in homogenates of the cells at concentrations of substrate, coenzymes and cofactors that gave maximal oxidation rates (18). The oxidation capacity of $\mathrm{CMC}$ was $2.31 \pm 0.31 \mathrm{nmol} / \mathrm{min}$ per $\mathrm{mg}$ tissue protein. CEC and CFLC had a considerably lower oxidation capacity (table 4.1).

The distribution of the activity of the mitochondrial marker enzyme cytochrome C oxidase, measured in the homogenates of CMC, CEC and CFLC (table 4.1), indicated that the mitochondrial density was highest in $\mathrm{CMC}$.

The content of $\mathrm{H}-\mathrm{FABP}_{\mathrm{c}}$ was found to be $4.5 \pm 1.4 \mu \mathrm{g} / \mathrm{mg}$ tissue protein in $\mathrm{CMC}$, and $0.008 \pm 0.004 \mu \mathrm{g} / \mathrm{mg}$ tissue protein in CEC and $0.003 \pm 0.004 \mu \mathrm{g} / \mathrm{mg}$ tissue protein in CFLC (table 4.1). The detection level of the FABP-assay was $0.002 \mu \mathrm{g} / \mathrm{mg}$ tissue protein.

Table 4.1. Palmitatc oxidation rate, cytochrome $\mathrm{C}$ oxidase activity and $\mathrm{H}-\mathrm{FABP} \mathrm{P}_{\mathrm{c}}$ content in various cell types isolated from adult rat heart.

\begin{tabular}{|c|c|c|c|}
\hline Cell type & $\begin{array}{l}\mathrm{CMC} \\
(\mathrm{n}=4-6)\end{array}$ & $\begin{array}{l}\text { CEC } \\
(n=6)\end{array}$ & $\begin{array}{l}\text { CFLC } \\
(n=5)\end{array}$ \\
\hline $\begin{array}{l}\text { Palmitate oxidation rate } \\
(\mathrm{nmol} / \mathrm{min} \text { per mg tissue protein) }\end{array}$ & $2.31 \pm 0.31$ & $0.09 \pm 0.05$ & $0.31 \pm 0.19$ \\
\hline $\begin{array}{l}\text { Cytochrome } \mathrm{C} \text { oxidase } \\
\text { activity (U/mg tissuc protein) }\end{array}$ & $7.36 \pm 2.42$ & $0.28 \pm 0.10$ & $0.52 \pm 0.12$ \\
\hline $\begin{array}{l}\mathrm{H}-\mathrm{FABP} \\
(\mu \mathrm{g} / \mathrm{mg} \text { tissue protein })\end{array}$ & $4.5 \pm 1.4$ & $0.008 \pm 0.004$ & $0.003 \pm 0.004$ \\
\hline $\begin{array}{l}\text { Ratio H-FABP } \text { content to } \\
\text { palmitate oxidation rate } \\
\text { ( } \mu \mathrm{g} \cdot \mathrm{min} / \mathrm{nmol})\end{array}$ & $2.1 \pm 1.6$ & $0.096 \pm 0.055$ & $0.009 \pm 0.006$ \\
\hline
\end{tabular}

Data are expressed as means $\pm S D$ of the indicated number of cell preparations. $C M C$; cardiac mocytes, CEC; cardiac endothelial cells, CFLC; cardiac fibroblast-like cells.

* Assayed on 10,000 g supernatants of homogenates of the cell preparations. 


\subsection{DISCUSSION}

The present findings indicate that the main locus of cardiac fatty acid oxidation is the cardiomyocyte. Assuming that in the order of $90 \%$ of the cardiac protein is of cardiomyocytal origin, cardiomyocytes contribute by about $98 \%$ to the total cardiac fatty acid oxidation capacity. Other cardiac cells, such as endothelial cells take a very limited portion of the overall fatty acid oxidation capacity of cardiac tissue. This notion supports the observations made in isolated coronary microvascular cells as reported earlier (12).

On the basis of the specific activity of the mitochondrial marker enzyme cytochrome $\mathrm{C}$ oxidase it can be concluded that the contents of mitochondria in CEC and CFLC are considerably less than in CMC. The capacity to oxidize fatty acids is closely related to the activity of cytochrome $C$ oxidase and, hence, to the mitochondrial density of cells under investigation. Moreover the palmitate oxidation rate/cytochrome $\mathrm{C}$ oxidase activity ratio in the three cell types studied is mutually not significantly different $(0.34 \pm 0.02,0.36 \pm 0.23$ and $0.60 \pm 0.32$ for CMC, CEC and CFLC, respectively) using the Mann-Whitney $U$ test.

The bulk of fatty acids used for oxidative degradation is supplied to the heart from the vascular compartment. Fatty acids are assumed to cross the endothelium, separating the vascular and interstitial compartment, directly through the cytoplasm of the endothelial cells. Since fatty acids have a low aqueous solubility, intracellular carriers are most likely required for their transport from the luminal to the abluminal site of the endothelial cell. Analogously, carrier moieties are also needed in cardiomyocytes to transport fatty acids from the site of entry, i.e. the myocyte plasma membrane to the mitochondria, which are the main locus of fatty acid oxidation in heart tissue. FABP has been proposed to fulfill this fatty acid-carrier role $(5,14)$. In this respect, it should be mentioned that for a number of organs a quantitative relation exists between the fatty acid oxidation capacity and the cytosolic capacity to bind fatty acids (7), suggesting a close functional relationship between fatty acid binding, most likely by a specific cytoplasmic fatty acid-binding protein $\left(\mathrm{FABP}_{\mathrm{c}}\right)$, and mitochondrial fatty acid oxidation.

In concert with this notion, in isolated $\mathrm{CMC}$ a relatively high fatty acid oxidation capacity was observed to be associated with a relatively high content of FABP. However, a divergent picture emerges from data obtained in CFLC and CEC. Although, the palmitate oxidation rate to cytochrome $C$ oxidase activity is not significantly different from that of $\mathrm{CMC}$, the $\mathrm{H}-\mathrm{FABP}_{\mathrm{c}}$ content to palmitate oxidation rates are significantly lower, being approximately $0.5-5 \%$ of that measured in CMC (table 4.1).

The present findings of very low $\mathrm{H}-\mathrm{FABP}_{\mathrm{c}}$ levels in CEC disagree with earlier observations by Fournier and colleagues (5), who calculated from electron microscopic immunocytochemical studies that the level of FABP in the cardiac endothelial cell is about half of that in the cardiomyocyte. A possible explanation for this striking discrepancy is that CEC contain FABP(s) to which the polyclonal 
antibody (raised against rat $\mathrm{H}-\mathrm{FABP}_{\mathrm{c}}$ ), as used in the present study, does not react to any significant extent. When this is true, at least two different FABPs have to be present in the heart, one localized in the cardiomyocytes and a second one in endothelial and/or fibroblast-like cells. Experiments have to be done to measure the capacity of a cytosolic protein preparation from isolated CEC to bind fatty acids, so as to identify the possible presence of an endothelial-specific FABP. Alternatively, with CEC and CFLC the recovery of $\mathrm{H}-\mathrm{FABP}_{\mathrm{c}}$ in the supernatant after centrifugation of the homogenate could be highly incomplete, e.g. due to protein binding to membrane structures. It should be stressed that this is a rather theoretical explanation, since no other type of FABP shows this particular feature that might underestimate the actual content of this binding protein in the cytosolic fraction Finally, during culture, CEC and CFLC could possibly lose their ability to produce FABP. However no differences in $\mathrm{H}-\mathrm{FABP}_{\mathrm{c}}$ content was measured in passages one, two or three of $\operatorname{CEC}(12.9,5.7$ and $8.3 \mathrm{ng} / \mathrm{mg}$ tissue protein respectively).

Assuming that extrapolation of the present in vitro findings of very limited amounts of $\mathrm{H}-\mathrm{FABP}_{\mathrm{c}}$ in $\mathrm{CEC}$ to cardiac endothelial cells in situ is allowed, the virtual lack of fatty acid-binding proteins in this particular cell type might have consequences for the mechanism of transendothelial transport of long-chain fatty acids and their transfer from the cell membrane to the mitochondrial site of oxidation inside the endothelial cells. However, low cytoplasmic FABP levels do not automatically imply that endothelial cells form an impermeable barrier for fatty acyl moieties. Because the relatively short distance between the luminal and abluminal membrane of the endothelial cell, non-protein bound diffusion of fatty acids may be sufficiently high to fulfill the requirement of the endothelial and parenchymal cells for this important substrate.

\subsection{SUMMARY}

Heart tissue contains an appreciable amount of $\mathrm{H}-\mathrm{FABP}$. FABP is thought to play a crucial role in the transport of fatty acids from the cellular membrane to the intracellular site of oxidation and also, in case of endothelial cells, in the transfer of fatty acids from the vascular to the interstitial compartment through the endothelial cytoplasm. The present study was designed to assess the content of FABP in various cell types, including CMC, CEC and CFLC isolated from adult rat heart. Moreover, the possible quantitative relationship between the capacity of different cell types in the heart to oxidize fatty acids and the presence of FABP was delineated. Palmitate oxidation capacities, measured in homogenates of the isolated cells, were $2.31 \mathrm{nmol} / \mathrm{min}$ per $\mathrm{mg}$ tissue protein in freshly isolated CMC, but only 0.09 and $0.31 \mathrm{nmol} / \mathrm{min}$ per $\mathrm{mg}$ tissue protein in cultivated CEC and CFLC, respectively. Palmitate oxidation rates were closely related to the cytochrome $\mathrm{C}$ oxidase activity and, hence, to the mitochondrial density in the cells under investigation. In $\mathrm{CMC}$ the content of $\mathrm{H}-\mathrm{FABP}_{\mathrm{c}}$ was about $4.5 \mu \mathrm{g} / \mathrm{mg}$ tissue protein. However, in CEC and CFLC the $\mathrm{H}-F A B P_{c}$ content was 0.008 and 0.003 
$\mu \mathrm{g} / \mathrm{mg}$ tissue protein, respectively, corresponding to at maximum $0.2 \%$ of the $\mathrm{H}$ $\mathrm{FABP}_{\mathrm{c}}$ content of CMC. These findings indicate a marked difference between $\mathrm{CMC}$ and non-myocytal cells in the heart regarding their capacity to oxidize fatty acids, and a marked disproportion between the fatty acid oxidation capacity and immunochemically determined $\mathrm{H}-\mathrm{FABP}_{\mathrm{c}}$ content in both CEC and CFLC. The functional implication of these observations remains to be elucidated.

\section{Acknowledgement}

The authors thank Frans van Nieuwenhuizen for performing additional ELISA's on FABP.

\subsection{REFERENCES}

1 Bass NM (1988) The cellular fatty acid binding proteins: aspects of strueture, regulation and function. Int Rev Cytol 111: 143-184

2 Bassingthwaighte JB, Noodleman L, van der Vusse G, Glatz JFC (1989) Modeling of palmitate transport in the heart. Mol Cell Biochem 88: 45-49

3 Börchers T, Unterberg C, Ruidel H, Robenek H, Spener F (1989) Subcellular distibution of cardiac fatty acid-binding protein in bovine heart muscle and quantification with an enzymelinked immunosorbent assay. Biochim Biophys Acta 1002: 5461

4 Crisman TS, Claffey KP, Saouaf R, Hanspal J, Brecher P (1987) Measurement of rat heart fatty acid binding protein by ELISA. Tissue distribution, developmental changes and subcellular distribution. J Mol Cell Card 19: 423-431

5 Fournier NW, Rahim M (1985) Control of energy production in the heart: a new function for fatty acid binding protein. Biochem 24: 2387-2396

6 Glatz. JFC, Baerwaldt CCF, Veerkamp JH, Kempen HJM (1984) Diurnal variation of cytosolic fatty acid-binding protein content and of palmitate oxidation in rat liver and heart. J Biol Chem 25: 4295-4300

7 Glatz JFC, Van der Vusse GJ (1989) Intracellular transport of lipids. Mol Cell Biochem 88: 37.44

8 Glatz JFC, Veerkamp JH (1982) Postnatal development of palmitate oxidation and mitochondrial enzyme activities in rat cardiac and skeletal muscle. Biochim Biophys Acta 711 : 327-335

9 Gohil K, Jones DA, Edwards RHT (1981) Analysis of muscle mitochondrial function with techniques applicable to needle biopsy samples. Clin Physiol 1: 195-207

10 Lowry OH, Rosebrough NJ, Farr AL, Randall RJ (1951) Protein measurement with the folin phenol reagent. J Biol Chem 193: 265-275

11 Neely JR, Rovetti MJ, Oram JF (1972) Myocardial utilization of carbohydrate and lipids. Prog Cardiov Dis 15: 289-329

12 Spahr R, Krutzfeldt A, Mertens S, Siegmund B, Piper HM (1989) Fatty acids are not an important fuel for coronary microvascular cells. Mol Cell Biochem 88: 59-64

13 Van der Vusse GJ, Prinzen FW, Van Bilsen M, Engels W, Reneman RS (1987) Accumulation of lipids and lipid-intermediates in the heart during ischaemia. Basic Res Cardiol 82 (suppl 1): $157-167$

14 Van der Vusse GJ, Glatz JFC, Stam HCG (1989) Myocardial fatty acid homeostasis. Mol Cell Biochem 88: 1-6

15 Van der Vusse GJ, Glatz JFC, Stam HCG, Reneman RS (1992) Fatty acid homeostasis in the normoxic and ischemic heart. Physiol Rev 72: 881-940 

CHAPTER 5

PRODUCTION OF ARACHIDONIC ACID METABOLITES IN ADULT RAT CARDIAC MYOCYTES, ENDOTHELIAL, CELLS, AND FIBROBLAST-LIKE CELLS

This chapter is published in

Linssen MCJG, Engels W, Lemmens PJMR, Heijnen VVTh, Van Bilsen M, Reneman RS, Van der Vusse GJ (1993) Production of arachidonic acid metabolites in adult rat cardiac myocytes, endothelial cells and fibroblast-like cells. Am J Physiol 264: H973-H982. 


\subsection{INTRODUCTION}

Arachidonic acid (AA) can be enzymatically oxidized to eicosanoids. Eicosanoids are substances acting as modulators in a multitude of (patho)physiological processes, such as thrombosis, inflammation, immune-response, tissue rheology and atherosclerotic disease $(27,36)$. Nowadays three metabolic pathways are known by which eicosanoids are generated (see refs. 32, 36 for review). The formation of prostaglandins (PG's) and thromboxanes (Tx's) is catalyzed in the cyclo-oxygenase pathway. The production of hydroxyeicosatetraenoic acids (HETE's) and leukotrienes (LT's) occurs in the lipoxygenase pathway. More recently the synthesis of epoxides, HETE's and diHETE's in an epoxygenase pathway has been described (31).

Under basal conditions the concentration of non-esterified AA in the heart is low $(13,16,26)$. The production and release of eicosanoids is enhanced when the heart is made ischemic and reperfused. Stimulation also occurs by agents such as the calcium ionophore A23187 or bradykinin (6), and by increasing the levels of exogenous AA $(17,19,26)$. Recent studies have shown that degradation of membrane phospholipids is a factor contributing to the irreversible loss of cardiac function during ischemia and reperfusion $(12,41,42)$. Hydrolysis of phospholipids is associated with an increase in the tissue level of non-esterified AA $(8,42)$, but it is unclear whether there is a direct relationship between the increased availability of AA and enhanced eicosanoid production in these conditions $(6,16,34,39)$.

Despite a number of attempts to identify the cellular site of eicosanoid production in cardiac tissue, no agreement exists regarding the cell type responsible for the production of eicosanoids in the heart $(19,20,24,34,43)$. Some investigators have suggested that vascular cells are the primary source of PG-synthesis, while contradictory results have been published regarding the capacity of cardiomyocytes to produce these substances $(1,2,18,23)$. No clear information is available about the capacity of fibroblast-like cells to synthesize eicosanoids.

The aims of this study were, firstly, to compare the capacity of various cell types of the heart to produce eicosanoids. To this end cardiomyocytes (CMC), endothelial cells (CEC) and fibroblast-like cells (CFLC) from adult rat hearts were used as experimental model. CMC were freshly used, whereas C.EC and CFLC were investigated after subcultivating the cells for 2 to 6 passages. The second aim of the study was to determine the type of eicosanoids formed and the amount released by the three above mentioned cell types under various conditions. Agents such as A23187, histamine and bradykinin were used to stimulate eicosanoid production. Eicosanoids were monitored with the use of a sensitive HPLC assay technique (44). In a subset of experiments 6-keto-PGF $F_{1 \alpha}$, the stable product of prostacyclin, and $\mathrm{PGE}_{2}$ were measured with a more sensitive radioimmunoassay. Thirdly, since the endothelial cells were found to display the highest production rate of eicosanoids in vitro, the time course of eicosanoid production by cardiac endothelial cells as a function of the concentration of 
exogenous $\mathrm{AA}$, in the absence or presence of the $\mathrm{Ca}^{2+}$ ionophore $\mathrm{A} 23187$, was investigated in more detail. Besides, the effect of the addition of albumin on endothelial eicosanoid production was monitored since exogenous AA is supplied to endothelial cells in vivo mainly complexed to albumin. These findings will be discussed in relation to previous studies $(15,16,26,40,42)$ carried out to examine the relationship between AA accumulation and eicosanoid formation in cardiac tissue.

\subsection{METHODS}

\section{Animals and isolation of cells}

Male adult Wistar or Lewis rats of 12 weeks were used. CMC, CEC and CFLC were isolated from the hearts in sterile conditions by a modification of the methods of Piper et al. (33) and Diglio et al. (14) and described in chapter 2.

\section{Incubation of cells for eicosanoid production}

CEC and CFLC after passage two and primary CMC on dishes with a diameter of $10 \mathrm{~cm}$ were washed three times with Hanks' Balanced Salt Solution (HBSS) with $10 \mathrm{mM}$ HEPES and covered with $4 \mathrm{ml}$ incubation medium HBSS. Calcium ionophore (A23187) and/or AA were present when indicated.

The cells were incubated in a humidified $95 \%$ air plus $5 \% \mathrm{CO}_{2}$ stove at $37^{\circ} \mathrm{C}$ for $30 \mathrm{~min}$. Thereafter the supernatant was collected for eicosanoid determination and the remaining cells were lysed in $1 \mathrm{M} \mathrm{NaOH}$ for $30 \mathrm{~min}$ at $37^{\circ} \mathrm{C}$ for protein determination according to Bradford et al. (4). In a subset of experiments cells were scraped from the plate and their eicosanoid content was analyzed. On the average, a $10 \mathrm{~cm}$ dish with a confluent layer of non-cardiomyocytes (approximately $2.10^{6}$ cells), contained $0.1-0.4 \mathrm{mg}$ cellular protein. A dish with on the average $10^{5} \mathrm{CMC}$ contained about $0.5 \mathrm{mg}$ cellular protein.

A23187 was dissolved in dimethyl sulfoxide $(10 \mathrm{mM})$, and bradykinin and histamine were dissolved in water $(1 \mathrm{mM}$ and $0.1 \mathrm{mM}$, respectively) and prior to administration diluted one to thousand in HBSS. Before use, AA was purified by silicagel column chromatography; elution was performed with $90 \%$ hexane plus $10 \%$ diethylether and yielded a purified AA fraction. After drying under a stream of nitrogen, purified AA was dissolved in ethanol. The concentration of AA in ethanol amounted to $80 \mathrm{mM}$.

In a subset of experiments cells were treated with indomethacin $(10 \mu \mathrm{M})$. The drug was dissolved at a concentration of $20 \mathrm{mM}$ in ethanol. Cells were preincubated with indomethacin for $15 \mathrm{~min}$. This drug was also present in the final incubation medium. 
In some experiments an AA-BSA complex was used. To this end $8 \mathrm{mM} \mathrm{KOH}$ was added to $8 \mathrm{mM} \mathrm{AA}$ in ethanol. After evaporation of ethanol by a stream of nitrogen at $37^{\circ} \mathrm{C}$ fatty acid free BSA, dissolved in water, was added. The AA-BSA stock solution concentration was $1.6 \mathrm{mM}$ AA/2 mM BSA. The final AA concentration was varied by diluting the stock solution with HBSS containing 200 $\mu \mathrm{M}$ BSA.

Since the production of AA metabolites by cultured human umbilical vene endothelial cells (HUVEC) has been extensively studied $(3,21,22,25,37)$, these cells were used to obtain reference values. HUVEC were isolated and cultured according to Bruggeman et al. (5).

\section{Electron microscopy}

For transmission electron microscopy cells were grown on thermanox tissue culture coverslips incubated with AA and/or A23187, fixed and further treated as described in chapter 2.

Determination of prostaglandins, thromboxane, hydroxy fatty acids and leukotrienes

Prostaglandins, thromboxane, hydroxy fatty acids [hydroxyeicosatetra-enoic acid (HETE), 12-hydroxyheptadecatrienoic acid (HHT) and leukotrienes (LT)] were determined as previously described $(15,17)$. Hereto the supernatants of cell incubations were purified on a $C_{18}$ reversed-phase column after addition of internal standards and acidification to $\mathrm{pH} 4.0-4.5$. After pre-elution of these columns with methanol/water (15/85, by vol) followed by acidified water $(\mathrm{pH}=4.0)$, the eicosanoid fraction was eluted with methanol and dried with a stream of nitrogen at $40^{\circ} \mathrm{C}$. The dried residues obtained from the cell supernatants were used directly to measure leukotrienes (17) or further purified with silicagel column chromatography (15). Stepwise elution of these columns yielded purified fractions containing HETE/HHT and prostaglandins/thromboxane, respectively. The HETE/HHT fraction was directly applied to reversed-phase HPLC with ultraviolet detection at $235 \mathrm{~nm}$ (15). The eluted prostaglandin/thromboxane fraction was methoximated, esterified with panacyl bromide and analyzed by reversed-phase HPLC with fluorimetric detection (15). Figure 5.1 shows a representative HPLC profile. The practical lower limits of detection of prostaglandins/thromboxane $B_{2}$. HETE/HHT and LT were 0.15 pmol injected on column. Routinely one fifth $(20 \mu \mathrm{l})$ of purified sample was injected on the column. This implies that at least $0.75 \mathrm{pmol}$ should be present in the incubation fluid or cell extract to be detectable by the HPLC assay technique. The overall recoveries of prostaglandins/thromboxane $B_{2}$ and HETE/HHT in the assay were $61-72 \%$ and $74-86 \%$, respectively. 


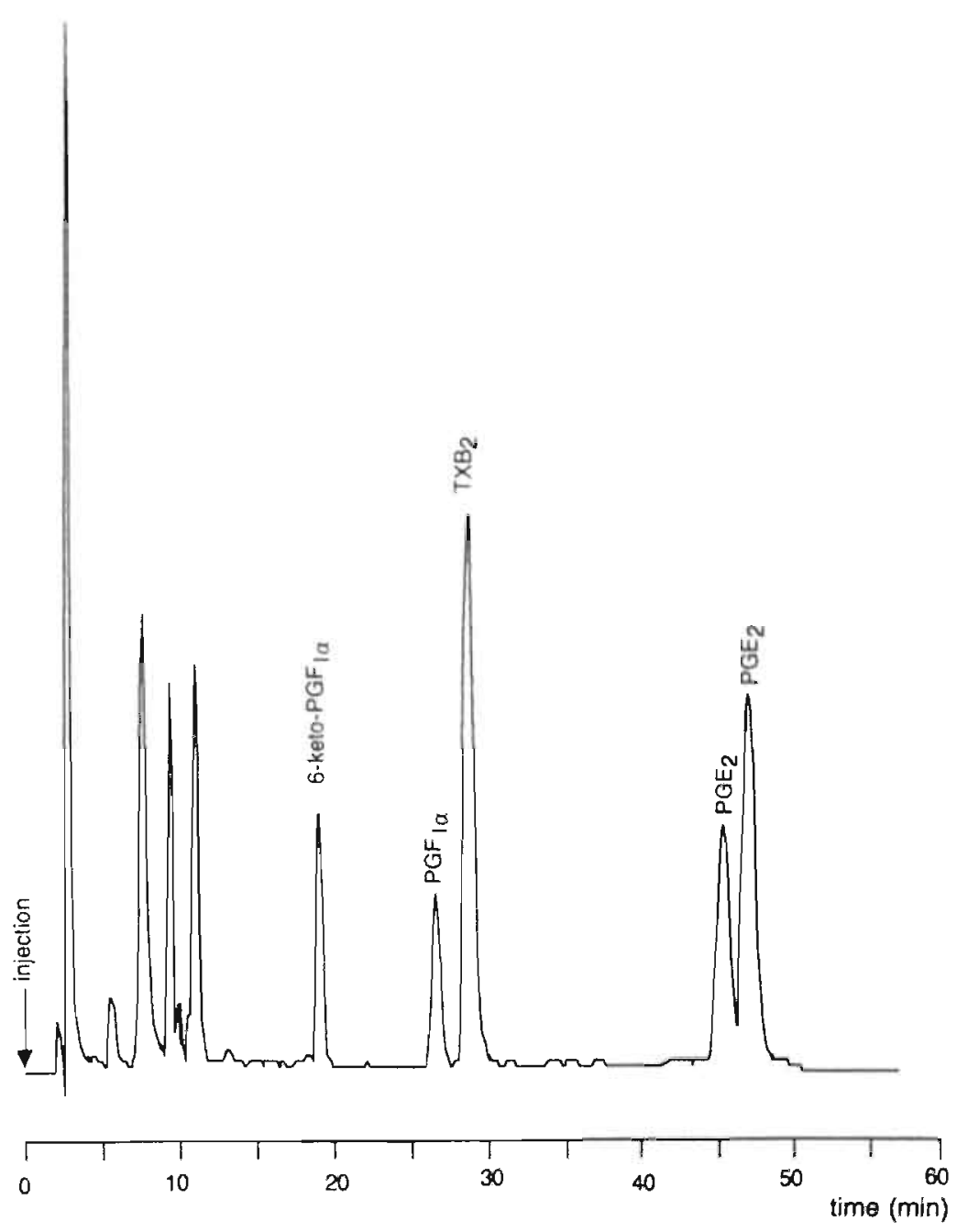

Figure 5.1. Representative high-performance liquid chromatography profile. Data reflect analysis of a typical experiment of cardiac endothelial cells incubated in the presence of arachidonic acid $(A A ; 80 \mu M)$ for 30 min. 6-Keto-PGF $1 \alpha$, 6-keto-prostaglandin $F_{1 a} ; P G F_{1 a}$ and $P G E_{2}$, prostaglandins $F_{1 \alpha}$ and $E_{2}$, respectively; $T x B_{2}$, thromboxane $B_{2}$.

Radioimmunoassay of 6-keto- $P G F_{1 \alpha}$ and $P G E_{2}$

Since we failed to detect 6-keto-PGF $1 \alpha$ (the stable metabolite of prostacyclin) in the supernatants of CMC with the use of the earlier described HPLC method, a more sensitive radioimmunoassay was applied for the detection of this eicosanoid. Hereto, the cell supernatants $(4 \mathrm{ml})$ were acidified to $\mathrm{pH} 5.5-6.0$ and applied to $\mathrm{C}_{18}$ reversed-phase columns as described by Zijlstra et al. (44). 

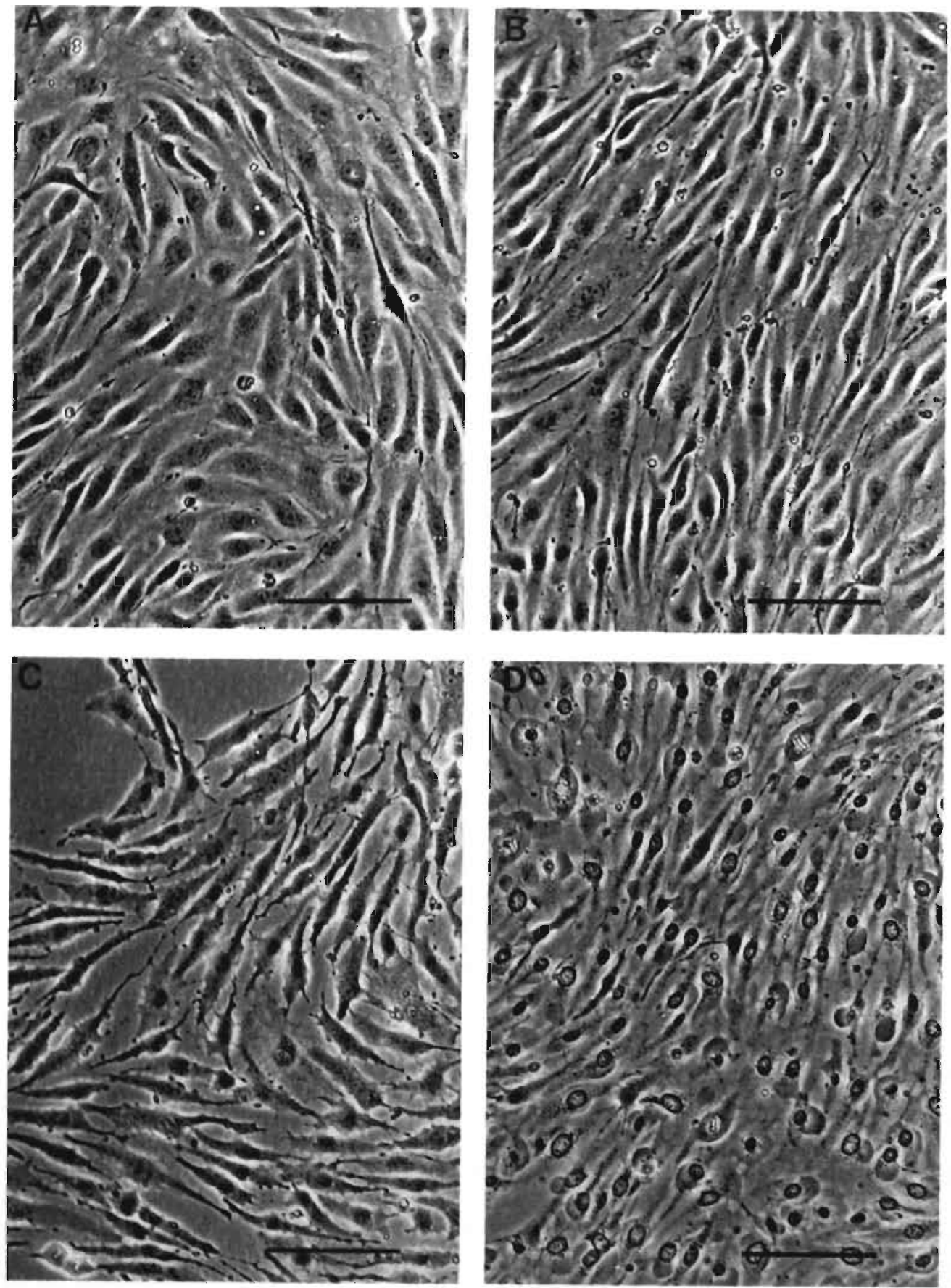

Figure 5.2. Phase contrast light micrographs of culured endothelial cells (CEC) and myocytes (CMC) from adill rat heart. A: confluent CEC after 60 min control incubation. B: confluent CEC after $30 \mathrm{~min}$ incubation with $80 \mu \mathrm{M}$ of arachidonic acid (AA). C: confluen CEC after $60 \mathrm{~min}$ imcubation with $80 \mu \mathrm{M}$ of AA. D: confluent CEC after 60 min of incubation with $10 \mu \mathrm{M}$ of 

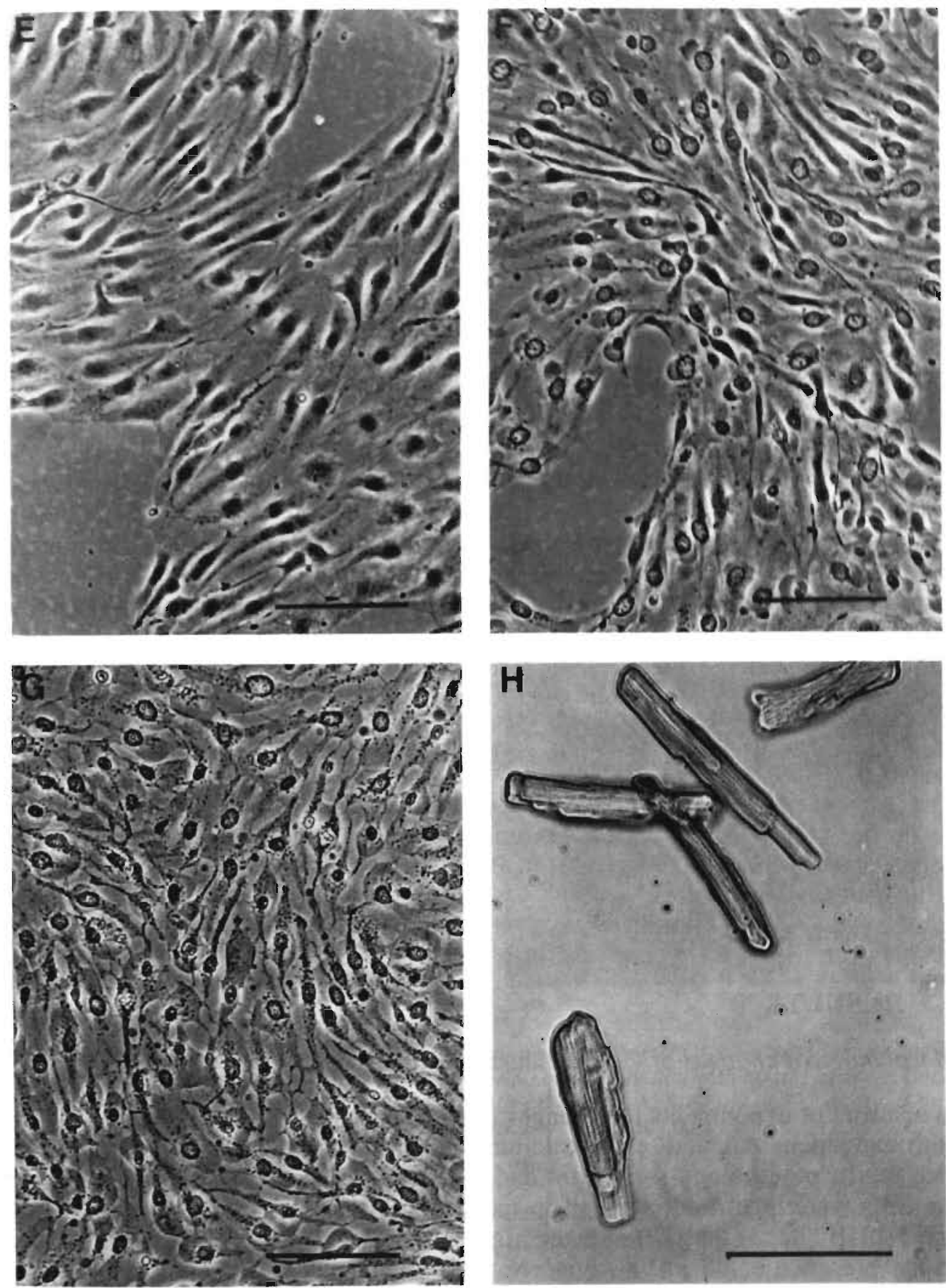

(Figure 5.2 continued). E: confluent CEC after 10 min incubation with $10 \mu M$ of A23187 and 80 $\mu M$ of AA. F: confluent CEC after 30 min of incubation with $10 \mu M$ of A23187 and $80 \mu M$ of AA. $G$ : confluent CEC after 60) min of incubation with $10 \mu \mathrm{M}$ of A23187 and $80 \mu \mathrm{M}$ of AA. H: CMC after 30 min of incubation with $10 \mu M$ of $A 23187$ and $80 \mu M$ of AA. Bar represents $0.1 \mathrm{~mm}$. 
In a subset of experiments cells were collected in water with the use of a cellscraper and extracted in chloroform/water. Thereafter the cellular extracts were also applied to $C_{18}$ reversed-phase columns. The eluted fractions were dried with a stream of nitrogen at $40^{\circ} \mathrm{C}$ and resuspended in radioimmunoassay buffer. The radioimmunoassay of 6-keto- $\mathrm{PGF}_{1 \alpha}$ and $\mathrm{PGE}_{2}$ was performed according to the manufacturer's instructions (Advanced Magnetics Inc., Cambridge, MA, USA). The practical lower detection limit of $6-$ keto- $\mathrm{PGF}_{1 \alpha}$ and $\mathrm{PGE}_{2}$ was estimated to be $27 \mathrm{fmol}$ per assay. Routinely one fifth $(200 \mu \mathrm{l})$ of purified cell extracts or incubation fluids were assayed. This implies that at least $135 \mathrm{fmol}$ should be present in the incubation medium or cell extract to be detectable. Validation of the radioimmunoassays was performed by comparing the values of 6-keto-PGF 1 a produced by CFLC and determined by radioimmunoassay with those assessed by the HPLC method. An acceptable correlation $\left(r_{3}=0.91\right)$ between both assays could be established (data not shown).

\section{Materials}

Unless otherwise stated all chemicals were obtained from Merck (Darmstadt, FRG). A23187, bradykinin, histamine, arachidonic acid, indomethacin, BSA V (essentially fatty acid free) and L-lysine were obtained from Sigma Chemical Co. (St Louis, MO USA). The Falcon tissue culture dishes were obtained from Becton Dickinson Ltd. (Playmouth, UK). Thermanox tissue culture coverslips were obtained from Miles Laboratories Inc. (Naperville, IL USA).

\section{Statistics}

The data are presented as mean values \pm SD or SEM. The number of experiments per group varied from 4 to 9 . Differences between groups were tested with the nonparametric Mann-Whitney $U$ test. $P$ values less than 0.05 were considered to be statistically significant.

\subsection{RESULTS}

\section{Morphological changes of CEC during incubation with AA andlor A23187}

In a subset of experiments the changes in morphology of CEC during incubations with exogenous AA and/or the calcium ionophore A23187 were monitored. No changes in morphology were light and electron microscopically observed when the cells were incubated in the plain incubation buffer, i.e. in the absence of AA and $A 23187$, for at least 60 minutes (figs. 5.2a, 5.3a). When CEC were incubated in the presence of $80 \mu \mathrm{M}$ AA, morphological changes at the light microscopic level were absent during the first 30 min of incubation (fig. 5.2b). Less than $20 \%$ of the cells incubated in the presence of $80 \mu \mathrm{M} \mathrm{AA}$ for $30 \mathrm{~min}$ showed ultrastructural changes (fig. $5.3 \mathrm{~b}$ ). Thereafter the cells became more elongated and frayed (fig. 5.2c). When CEC were exposed to A23187, the cells started to round up above the nucleus after $10 \mathrm{~min}$. 

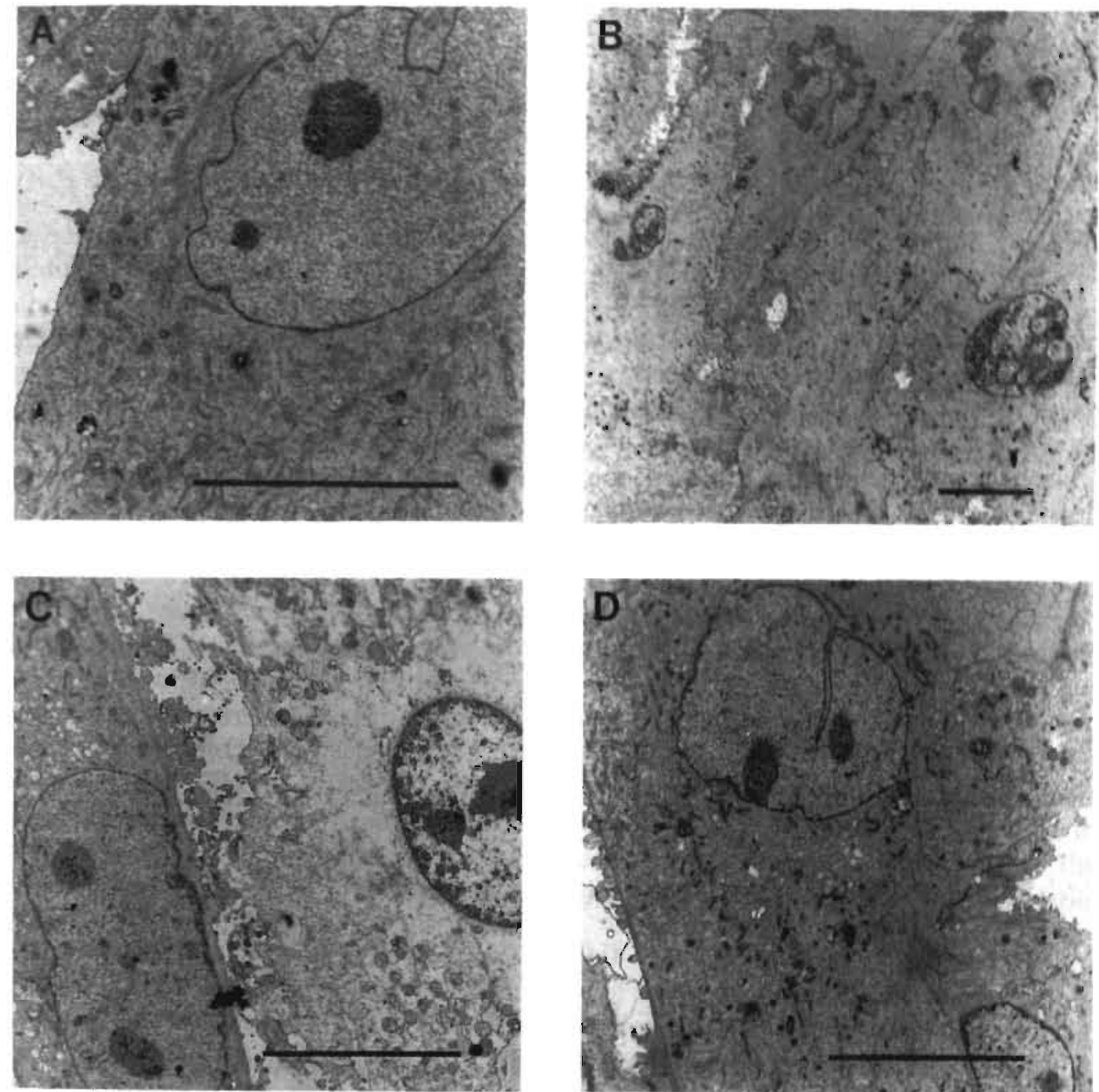

Figure 5.3. Electron micrographs of cultured endothelial cells (CEC) from adult rat heart. A: CEC after 30 min control incubation. B: CEC after 30 min incubation with $80 \mu M$ of arachidonic acid (AA), C: CEC after $30 \mathrm{~min}$ incubation with $10 \mu \mathrm{M}$ of A23187. D: CEC after $30 \mathrm{~min}$ incubation with $10 \mu \mathrm{M}$ of $\mathrm{A23} 187$ and $80 \mu \mathrm{M}$ of $\mathrm{AA}$. Bar represents $0.01 \mathrm{~mm}$.

With longer exposure time the cells formed cytoplasmatic extrusions (fig. 5.2d). Electron microscopic evaluation revealed that about $50 \%$ of CEC exposed to 10 $\mu \mathrm{M}$ A.23187 were necrotic after $30 \mathrm{~min}$ of incubation (fig. 5.3c). Addition of AA to an A23187 containing incubation buffer considerably attenuated the effect of the calcium ionophore. When both A23187 $(10 \mu \mathrm{M})$ and AA $(80 \mu \mathrm{M})$ were added to the incubation medium, the cells started to round up after 10 to $20 \mathrm{~min}$ of incubation (fig. 5.2e). After 20 to 30 min extrusions became visible (fig. 5.2f) and after $60 \mathrm{~min}$ of incubation more or less elongated cells with grubby appearance were seen (fig. $5.2 \mathrm{~g}$ ). Electron microscopic observation showed that 
ultrastructurally $85 \%$ of the cells were intact after 30 min of incubation with 10 $\mu \mathrm{M}$ of $\mathrm{A} 23187$ and $80 \mu \mathrm{M}$ of AA (fig. $5.3 \mathrm{~d}$ ).

The CMC generally did not reveal significant morphological changes at the light

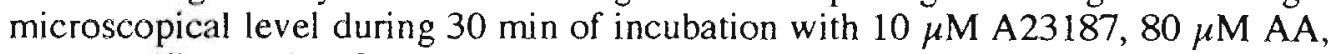
or both (fig. $5.2 \mathrm{~h}$ ). Occasionally the percentage rod shaped cells was slightly reduced after incubation with $10 \mu \mathrm{M} \mathrm{A} 23187$ and $80 \mu \mathrm{M} \mathrm{AA}$.

\section{Production of eicosanoids}

Comparison between different cell types. Isolated CMC, CEC and CFLC were routinely incubated in the presence of $10 \mu \mathrm{M} \mathrm{A23187}$ and $80 \mu \mathrm{M}$ AA for $30 \mathrm{~min}$, unless otherwise stated. As shown in table 5.1 the amounts of individual eicosanoids produced and released into the incubation medium, and the summated amounts greatly differed among the various cell types studied. The highest production rate was displayed by CEC. On the average $23 \mathrm{nmol}$ eicosanoids per mg cellular protein were synthetized and released by CEC per 30 min incubation (table 5.1).

Table 5.1. Release of eicosanoids in CEC, CFLC, and CMC isolated from adult rat heart and in HUVEC.

\begin{tabular}{lcccc}
\hline & CEC & CFLC & CMC & HUVEC \\
\hline $\mathrm{n}$ & 7 & 6 & 5 & 9 \\
sum & $23.2 \pm 4.5$ & $2.01 \pm 0.38$ & & $3.82 \pm 0.73$ \\
11 -HETE & $1.57 \pm 0.20$ & $0.04 \pm 0.04$ & $<0.008$ & $0.07 \pm 0.02$ \\
15 -HETE & $2.02 \pm 0.52$ & $0.11 \pm 0.05$ & $<0.008$ & $0.40 \pm 0.11$ \\
HHT & $7.21 \pm 1.55$ & $0.26 \pm 0.04$ & $<0.008$ & $0.77 \pm 0.13$ \\
6-keto-PGF & $0.12 \pm 0.09$ & $0.62 \pm 0.20$ & $<0.008$ & $0.25 \pm 0.06$ \\
PGE $_{2}$ & $7.09 \pm 2.22$ & $0.97 \pm 0.30$ & $<0.008$ & $1.69 \pm 0.32$ \\
PGF $_{2 \alpha}$ & $1.23 \pm 0.50$ & $0.02 \pm 0.01$ & $<0.008$ & $0.64 \pm 0.47$ \\
TxB $_{2}$ & $3.97 \pm 2.22$ & $<0.008$ & $<0.008$ & $<0.008$ \\
\hline
\end{tabular}

Values are means $\pm S D$ expressed in nmol.mg protein ${ }^{-1} .30 \mathrm{~min}^{-1} ; n$, no. of experiments. Cells were incubated with $10 \mu \mathrm{M}$ of $\mathrm{A} 23187$ and $80 \mu \mathrm{M}$ of arachidonic acid at $37^{\circ} \mathrm{C}$ for $30 \mathrm{~min}$. CEC, cardiac endothelial cells; CFLC, cardiac fibroblast-like cells; $C M C$. cardiomyocytes; HUVEC, human umbilical vein endothelial cells; 11-HETE, 11hydroxyeicosatetraenoic acid; 15-HETE, 15-hydroxyeicosatetraenoic acid: HHT, 12 hydroxyheptadecalrienoic acid; 6-keto-PGF $1 \alpha$, 6-kelo-prostaglandin $F_{1 a} ; P G E_{2}$, prosiaglandin $E_{2} ; P G F_{2 a}$. prostaglandin $F_{2 a}: T x B_{2}$, thromboxane $B_{2}$. Eicosanoids present in incubation medium were determined with the use of a high-performance liquid chromatography technique. 
The production by CFLC was considerably less and amounted to $2 \mathrm{nmol} / \mathrm{mg}$ per 30 min. The amount of eicosanoids produced by isolated CMC was below the detection limit of the HPLC assay used $(<0.00015 \mathrm{nmol} /$ assay corresponding with on the average $0.008 \mathrm{nmol} / \mathrm{mg}$ protein per $30 \mathrm{~min}$ ). The production of eicosanoids in HUVEC was on the order of $4 \mathrm{nmol} / \mathrm{mg}$ protein per $30 \mathrm{~min}$, a value comparable with that found by other investigators $(22,25)$.

When a more sensitive radioimmunoassay was applied to monitor the release of 6 keto- $\mathrm{PGF}_{1 \alpha}$, the stable degradation product of prostacyclin, by CMC a value of about $2 \mathrm{pmol} / \mathrm{mg}$ protein per $30 \mathrm{~min}$ was obtained (data not shown). The production of 6 -keto-PGF $1 \alpha$ by $\mathrm{CEC}$ was found to be $120 \mathrm{pmol} / \mathrm{mg}$ protein per 30 min, whereas HUVEC and CFLC released 250 and $620 \mathrm{pmol} / \mathrm{mg}$ protein per 30 min, respectively (table 5.1). For all the other metabolites measured, CEC produced the largest amounts. Only CEC were capable of producing thromboxane $\mathrm{B}_{2}\left(\mathrm{TxB}_{2}\right)$, the stable degradation product of $\mathrm{TxA}_{2}$. Formation of leukotrienes was undetectable in either cell preparation.

Comparison between the physiological agonists bradykinin and histamine, and the calcium ionophore A23187. In order to determine the effect of bradykinin and histamine, CMC and CEC were incubated in the presence of $1 \mu \mathrm{M}$ bradykinin or $0.1 \mu \mathrm{M}$ histamine for 30 minutes. No exogenous AA was added. The effect of the physiologically relevant stimuli on cellular eicosanoid production were compared with that of the $\mathrm{Ca}^{2+}$ ionophore A23187. The amount of 6-keto-PGF $1 \alpha$ and $\mathrm{PGE}_{2}$ was measured in both the incubation medium above the cells, and the cells themselves after being scraped from the plate. This experiment enables us to discriminate between the amount of eicosanoids produced and released into the incubation medium, and the amount sequestered in the cells at the bottom of the dish.

Table 5.2 indicates that under influence of bradykinin and histamine small amounts of 6-keto-PGF $1 \alpha$ and $\mathrm{PGE}_{2}$ were released into the incubation medium from both CEC and CMC. Only the histamine stimulated release of 6-keto-PGF $1 \alpha$ by CEC was significantly different from that of control, non-stimulated cells. The stimulating effect of A23187 on cellular release however, was found to be highly significant when compared with control incubations in both CEC and CMC.

Analysis of the cellular fraction revealed that the increase in the content of $6-$ keto- $\mathrm{PGF}_{1 \alpha}$ and $\mathrm{PGE}_{2}$ in $\mathrm{CMC}$ reached the level of significance $(\mathrm{p}<0.05)$ during 30 min of incubation in the absence of stimulating agents. When bradykinin, histamine or A23187 were included in the incubation medium the CMC content of 6-keto- $\mathrm{PGF}_{1 \alpha}$ and $\mathrm{PGE}_{2}$ did not further increase. In contrast, no significant increase in the content of 6-keto-PGF $1 \alpha$ and $\mathrm{PGE}_{2}$ was observed when $C \mathrm{CE}$ were incubated under control conditions for $30 \mathrm{~min}$. Addition of bradykinin, histamine and A23187 resulted in a significant increase of the cellular content of the two eicosanoids. 
Table 5.2. Amount of 6-keto-PGF 1 a and $\mathrm{PGE}_{2}$ in the incubation medium and cells after incubation with different stimuli.

\begin{tabular}{|c|c|c|c|c|}
\hline \multirow[b]{2}{*}{ cell type } & \multicolumn{2}{|c|}{ medium } & \multicolumn{2}{|c|}{ cellular content } \\
\hline & 6-keto-PGF $1 a$ & $\mathrm{PGE}_{2}$ & 6-keto-PGF ${ }_{1 \alpha}$ & $\mathrm{PGE}_{2}$ \\
\hline \multicolumn{5}{|l|}{$t=0 \mathrm{~min}$} \\
\hline CEC & & & $0.7 \pm 0.6$ & $34.7 \pm 22.7$ \\
\hline $\mathrm{CMC}$ & & & $0.2 \pm 0.1$ & $11.1 \pm 3.8$ \\
\hline \multicolumn{5}{|l|}{$t=30 \mathrm{~min}$} \\
\hline \multicolumn{5}{|l|}{ control } \\
\hline CEC & $<0.3$ & $1.7 \pm 2.4$ & $3.0 \pm 3.6$ & $62.3 \pm 94.2$ \\
\hline $\mathrm{CMC}$ & $0.3 \pm 0.5$ & $1.8 \pm 2.9$ & $12.7 \pm 12.1^{*}$ & $98.5 \pm 96.7^{*}$ \\
\hline \multicolumn{5}{|c|}{ bradykinin, $1 \mu \mathrm{M}$} \\
\hline $\mathrm{CEC}$ & $0.5 \pm 0.6$ & $5.7 \pm 4.9$ & $4.3 \pm 3.3^{*}$ & $117.8 \pm 93.4$ \\
\hline $\mathrm{CMC}$ & $2.0 \pm 2.9$ & $6.5 \pm 10.3$ & $14.2 \pm 14.4^{*}$ & $87.8 \pm 57.0^{*}$ \\
\hline \multicolumn{5}{|c|}{ histamine, $0.1 \mu \mathrm{M}$} \\
\hline CEC & $0.8 \pm 0.5^{\prime}$ & $4.3 \pm 2.6$ & $5.3 \pm 4.4^{*}$ & $145.3 \pm 150.8^{*}$ \\
\hline $\mathrm{CMC}$ & $2.5+2.5$ & $1.8 \pm 2.2$ & $14.7 \pm 6.9^{*}$ & $94.2 \pm 46.5^{*}$ \\
\hline \multicolumn{5}{|c|}{$\mathrm{A} 23187,10 \mu \mathrm{M}$} \\
\hline CEC & $20.5 \pm 17.6^{\prime}$ & $2268 \pm 2709$ & $4.2 \pm 4.2^{*}$ & $189.4 \pm 203.5^{*}$ \\
\hline $\mathrm{CMC}$ & $7.9 \pm 5.7^{\circ}$ & $12.6 \pm 10.4^{\prime \prime}$ & $8.1 \pm 8.1^{*}$ & $37.2 \pm 26.9^{*}$ \\
\hline
\end{tabular}

Values are means \pm SD expressed as pmol/mg protein. Eicosanoids were delermined with the use of a radioimmunoassay lechmique. Detection level of the radioimmunoassay is 135 fmol per sample. Each incubation comained $0.1-0.5 \mathrm{mg}$ protein. Number of experiments varied from 4 10 8 . * Significant different from cellular content a $t=0$. \# Significant different from control $t=30$ in the Mam- Whimey U tesi $(p<0.05)$. 
Time course of eicosanoid production. The time course of the production of AA metabolites was studied in more detail in CEC preparations. Data presented in figure 5.4 indicate that the rate of eicosanoid release was highest during the first 5 to $10 \mathrm{~min}$ of incubation with either $10 \mu \mathrm{M} \mathrm{A23187}$ or $80 \mu \mathrm{M}$ AA present in the incubation medium. The release leveled off thereafter. When both A23187 and AA were added the releasing rate reached its highest value within 5 min after the start of the addition of the stimulating agents. In general, comparable time patterns were seen for the individual eicosanoids released during the first $30 \mathrm{~min}$ (data not shown) as for the sum of AA metabolites (Fig. 5.4).

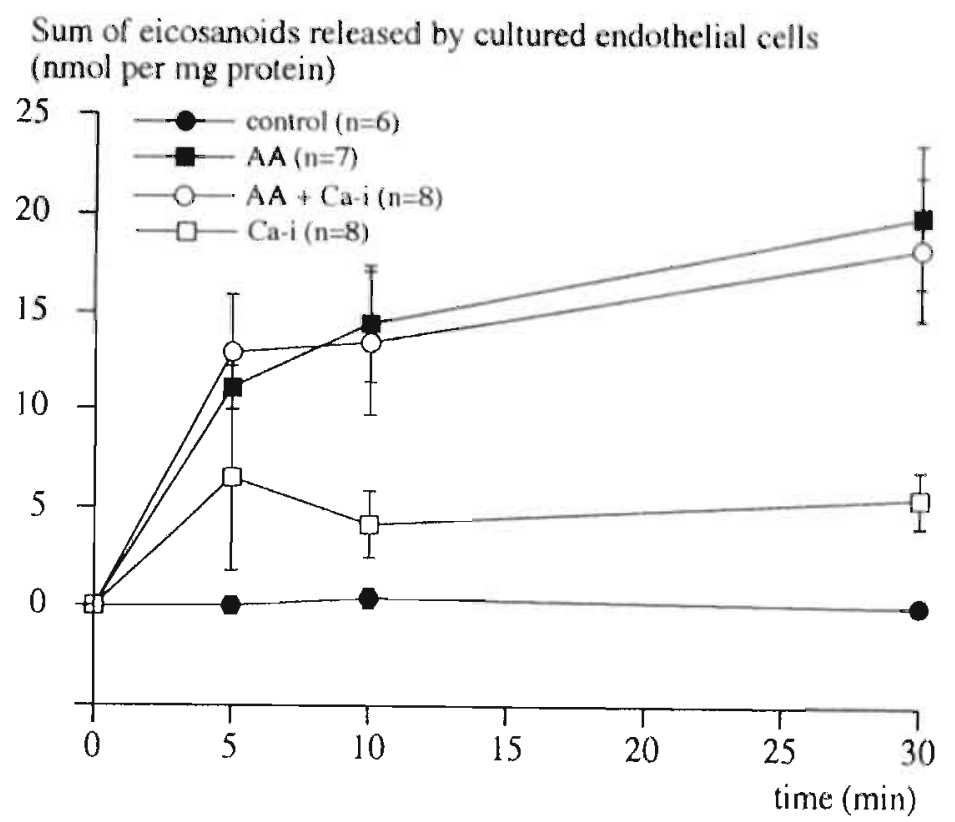

Figure 5.4. Time course of the sum of eicosanoids released from cultured cardiac endothelial cells. Data are expressed as nmol metabolites per mg cellular prolein $\pm S E$. Cells were stimulated with either the $\mathrm{Ca}^{2+}$ ionophore $\mathrm{A} 23187(\mathrm{Ca}-\mathrm{i} ; 10 \mu \mathrm{M})$ or arachidonic acid $(\mathrm{AA} ; 80 \mu \mathrm{M})$ or with a combination of both.

Influence of A23187 and of varying concentrations of exogenous AA on the production of eicosanoids. The production of eicosanoids in cultured cardiac endothelial cells was below the practical lower limit of detection of the currently applied HPLC technique (i.e. $0.75 \mathrm{pmol} / \mathrm{sample}$ ) when the cells $(0.1-0.5 \mathrm{mg}$ protein) were incubated in plain incubation medium. Addition of AA to the incubation medium stimulated the release of eicosanoids when the extracellular concentration of AA exceeded $10 \mu \mathrm{M}$ (Fig. 5.5a). For most eicosanoids maximal stimulation was reached at $80 \mu \mathrm{M}$ AA. The release of $\mathrm{TxB}_{2}, \mathrm{PGE}_{2}$ and $\mathrm{PGF}_{2 \alpha}$ declined at higher AA levels. In contrast, the release of HHT leveled off, whereas the amount of 11 - and 15-HETE increased linearly with increasing concentrations of extracellular AA above $80 \mu \mathrm{M}$. 
Addition of $10 \mu \mathrm{M} \mathrm{Ca}^{2+}$ ionophore A23187 had a substantial effect on the total amount of eicosanoids released when the exogenous concentration of $\mathrm{AA}$ was below $40 \mu \mathrm{M}$ (fig. 5.5b compared with 5.5a). $\mathrm{PGE}_{2}, \mathrm{TxB}_{2}$ and HHT were released in significant amounts. Interestingly, A23187 stimulated also the basal release (i.e. in the absence of exogenous $A A$ ) of $\mathrm{TxB}_{2}, \mathrm{HHT}$ and $\mathrm{PGE}_{2}$ in cardiac endothelial cells. At an extracellular AA concentration above $40 \mu \mathrm{M}$ the $\mathrm{Ca}^{2+}$ ionophore A23187 greatly enhanced the release of $\mathrm{PGE}_{2}$ (fig. 5.5b compared with 5.5a).

When AA was added to the incubation medium as fatty acid-albumin complex (at a fixed final concentration of $200 \mu \mathrm{M}$ BSA) in the presence of $10 \mu \mathrm{M} \mathrm{A23187,}$ the stimulating effect of exogenous AA on the release of eicosanoids by cardiac endothelial cells was appreciably attenuated (fig. 5.5c). At AA concentrations below $40 \mu \mathrm{M}$ the release was almost absent; higher concentrations of $\mathrm{AA}$, up to $160 \mu \mathrm{M}$, stimulated linearly the release of prostaglandins, $\mathrm{TxB}_{2}$ and HETE's.

Effect of indomethacin on the production of eicosanoids in CEC. When in a subset of experiments CEC were incubated in the presence of indomethacin $(10 \mu \mathrm{M})$ and AA $(80 \mu \mathrm{M})$, the release of products of the cyclooxygenase pathway (HHT, 6 keto-PGF $1 \alpha, \mathrm{PGE}_{2}, \mathrm{PGF}_{2 \alpha}$ and $\mathrm{TxB}_{2}$ ) was completely abolished. In contrast, $\mathrm{AA}$ induced release of the lipoxygenase pathway metabolites (11-HETE, 15-HETE and 5-HETE) remained unaffected by indomethacin (data not shown).

\subsection{DISCUSSION}

The findings in the present study on isolated CMC, CEC and CFLC of adult rat hearts strongly suggest that the main site of cardiac eicosanoid release is the endothelial cell, although fibroblast-like cells are also capable of producing these biologically active substances in appreciable amounts. Exogenous AA is required to fully stimulate eicosanoid release in endothelial and fibroblast-like cells. $\mathrm{Ca}^{2+}$ ionophore, A23187, administration in combination with AA has only an additional stimulatory effect on eicosanoid release when the AA concentration is below $40 \mu \mathrm{M}$. Exogenous AA complexed to albumin reduces the release of eicosanoids.

Figure 5.5 (facing page). Retease of individual eicosanoids from rat cardinc endothelial cells. A: varying concenirations of arachidonic acid (AA) in the absence of the $\mathrm{Ca}^{2+}$ ionophore $\mathrm{A23187}$ $(n=5)$. B: varying concentrations of $A A$ in the presence of $10 \mu M A 23187(n=8)$. $C$ : Varying concentrations of AA bound to $200 \mathrm{HM}$ (end concentration) bovine serum albumin in the presence of 10 fM A23187 $(n=6)$. Data are the mean values $\pm S E$. For the sake of clarity variation bars are only shown for the sum of the eicosanoids isum eicos; variation bars of individual eicosanoids are in the same range). Release is expressed in nmol AA metabolite per $m g$ tissue protein per $30 \mathrm{~min}$. 5-, 11 , and 15-HETE, 5, 11 -, and 15-hydroxyeicosatetraenoic acid respectively; $H H T, 12-$ hydroxy-heptadecatrienoic acid; 6-keto- $P G F_{l a}$. 6-keto-prostaglandin $F_{l a} \cdot P G E_{2}$, prostaglandin $E_{2}$; $P_{G F}$, prostaglandin $F_{2 a}: T x B_{2}$, thromboxane $B_{2}$. 
Release of eicosanoids by cultured endothelial cells

(nmol eicosanoids per $\mathrm{mg}$ protein per $30 \mathrm{~min}$ )
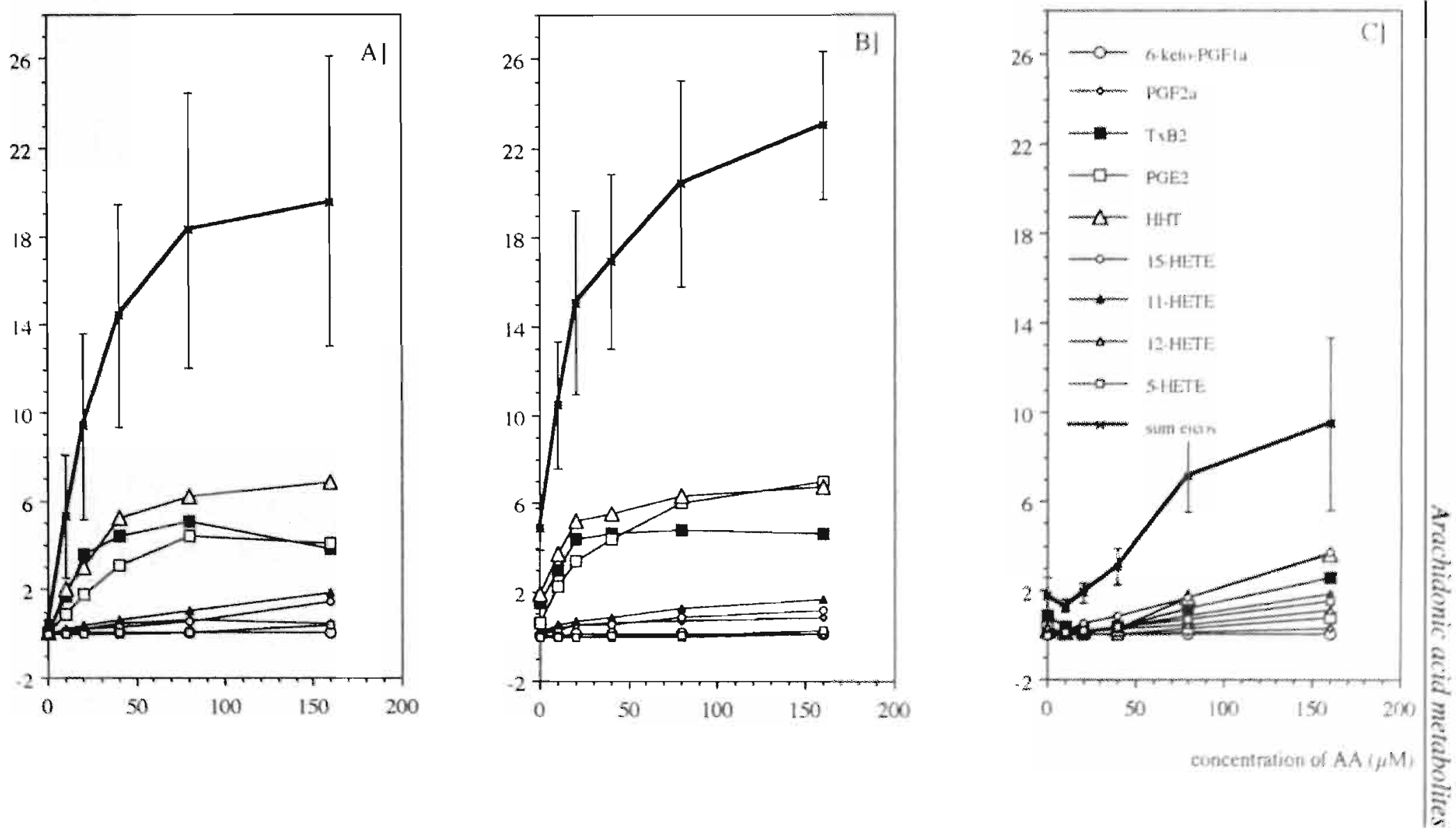
None of the cell types studied released leukotrienes. As the production rate in isolated AA and A23187-stimulated cells surpasses the rate of formation in the intact heart many folds and the types of in vitro produced eicosanoids greatly differ from the pattern released in intact hearts, a possible role of cardiomyocytes in in vivo cardiac eicosanoid, and in particular prostacyclin production, cannot be excluded.

Assuming that the maximal rates of eicosanoid release, as observed in vitro, reflect the amounts that can be produced in each specific cell type in vivo, the present data indicate that the contribution of cardiomyocytes to the overall formation of eicosanoids in the intact heart is limited. Taking into account that cardiac endothelial cells contribute on the order of $5 \%$ to the total cardiac protein content, whereas about $80 \%$ of the protein is of cardiomyocyte origin, the contribution of the latter cell type to the total amount of eicosanoids produced will not exceed $1 \%$ when all cell types are maximally stimulated. In a recent paper from our laboratory (17) it was reported that in isolated rat hearts, reperfused after a period of 60 min no-flow ischemia the production of 6-keto$\mathrm{PGF}_{\mathrm{I} \alpha}$ was on the order of $400 \mathrm{pmol} / \mathrm{g}$ wet weight per $30 \mathrm{~min}$. This value corresponds with about 3 pmol 6 -keto-PGF $1 \alpha$ produced per $\mathrm{mg}$ protein per 30 min. Comparable amounts were found to be released from isolated rat hearts stimulated with the $\mathrm{Ca}^{2+}$ ionophore $\mathrm{A} 23187$ (17). It is worthy to note that the amounts of 6-keto-PGF $1 \alpha$ released in intact hearts, stimulated by different factors, are on the same order of magnitude as the amounts released in isolated rod shaped CMC when stimulated with A23187 (table 5.2). Therefore, it cannot be excluded that the total production of 6 -keto-PGF ${ }_{1 \alpha}$, as observed in the intact heart, is released by the cardiomyocytes, despite their limited overall capacity to synthesize eicosanoids. However, it is unlikely that cardiomyocytes are the sole site of production in vivo since earlier studies of Hsue and colleagues (24) have convincingly shown that endothelial cells in situ play an active role in cardiac prostaglandin formation. Hence, the conclusion has to be drawn that the contribution of cardiomyocytes to the release of eicosanoids in fully stimulating conditions is limited, although in situ cardiomyocytes may contribute for an unknown proportion to the overall synthesis of eicosanoids in the heart since the production in intact hearts is very low compared to the release from isolated and cultured CEC and CFLC.

The present findings show that the pattern of eicosanoids released by cells isolated from adult rat hearts appreciably differs from the spectrum of AA metabolites produced by the intact heart. Studies on isolated, intact rat hearts subjected to either ischemia and reperfusion or $\mathrm{Ca}^{2+}$ ionophore treatment produced mainly 6keto-PGF $1 \alpha(16,17,26)$. In the reperfused hearts minor amounts of $\mathrm{TxB}_{2}$ were produced as well (16). Administration of A23187 to the perfusion medium results in the formation of leukotrienes $\mathrm{D}_{4}$ and $\mathrm{E}_{4}$ in addition to 6-keto-PGF $1 \alpha$ (17). The release of other eicosanoids obviously remains below the practical detection limit of the HPLC assay procedure applied. It cannot be excluded that isolation and subcultivation of cardiac cells alter the activity of the various enzymes involved in 
the production of AA metabolites. In this respect it is interesting to note that we found an 8 -fold increase in prostacyclin release in isolated CEC when endothelial cell growth factor and heparin were excluded from the culture medium (data not shown). Comparable findings have been reported for HUVEC $(3,22)$ and bovine pulmonary microvessel endothelial cells (9). In addition, other investigators have reported that variations in the rate of population doubling (25) and differences in cell density $(21,31)$ affect the amount of prostacyclin produced in vitro. The nature of the stimulus may also influence the most favored route in cellular eicosanoid synthesis $(11,35)$. When the concentration of exogenous AA is increased in the medium covering mouse cerebromicrovascular endothelial cells, the production of $\mathrm{PGE}_{2}$ is stimulated rather than that of prostacyclin $(7,31)$. Similar effects were observed in rat cardiac endothelial cells when the $\mathrm{Ca}^{2+}$ ionophore A23187 was applied (fig. 5.5b).

The failure of maximally stimulated isolated CMC, and CEC and CFLC to produce leukotrienes strongly suggests that other cell types are responsible for the production of these substances in vivo. Mast cells commonly present in cardiac tissue (28) may be likely candidates for the site of synthesis of leukotrienes in the intact rat heart.

The findings in the present study clearly indicate that CEC synthesize thromboxane $\mathrm{A}_{2}$ (fig. 5.5a, b, c). Similar findings have been reported in HUVEC $(21,37,38)$ and rat aortic endothelial cells $(10,30)$. This notion implicates that CEC are capable of releasing both prostacyclin and $T \times A_{2}$, eicosanoids with in general biologically adverse effects on microcirculatory function and platelets (35).

Earlier studies on intact ischemic and reperfused rat hearts have shown that enhanced eicosanoid production is a transient event $(16,17,26)$. Since under these circumstances AA steadily accumulated in the affected cardiac structures, lack of substrate is not a likely cause of the decline in eicosanoid formation. This conclusion is supported by the present findings, i.e. return of the rate of eicosanoid release to basal levels despite excess of exogenous AA. Autodestruction or self-deactivation of the enzymes involved may explain this characteristic pattern in the production rate (35). Mechanistically, oxygen free radicals produced in the course of eicosanoid synthesis may negatively affect the metabolic activity of the eicosanoid producing.enzymes (35). However it cannot be excluded that toxic properties of A23187 and/or the detergent action of AA contribute to the loss of metabolic action. In line with this assumption is the observation that endothelial cells change ultrastructurally when incubated in the presence of either A23187 or a combination of exogenous AA and the $\mathrm{Ca}^{2+}$ ionophore. Similar signs of damage of stimulated endothelial cells were observed by Revtyak et al. (35) in cultured bovine endothelial cells. However, the measured decrease in eicosanoid release occurs already after $10 \mathrm{~min}$ of incubation with AA and/or A23187 (fig. 5.4). Whereas the morphological changes occur after $30 \mathrm{~min}$ of incubation with AA (fig. 5.2c), after 20 min of incubation with AA and A23187 (fig. 5.2f), and after 10 min of incubation with A23187. 
It should be noted that the effect of physiological agents, such as bradykinin and histamine on the production of eicosanoids by isolated CEC and CMC was found to be limited when compared with the $\mathrm{Ca}^{2+}$ ionophore A23187. Although mean values of 6-keto- $\mathrm{PGF}_{1 \times}$ and $\mathrm{PGE}_{2}$ concentration in the medium above the cells after 30 minutes of stimulation with bradykinin or histamine was higher than control incubations in the absence of stimulating agents, the level of significance $(\mathrm{p}<0.05)$ was not reached with the exception of histamine stimulated release of 6keto-PGF ${ }_{1 \alpha}$ in CEC. Interestingly, the cellular content of 6-keto-PGF $F_{1 \alpha}$ and $\mathrm{PGE}_{2}$ increased during incubation under control conditions. The addition of stimulating agents to the incubation medium did not significantly influence the increase of the amount of eicosanoids sequestered in the cells (table 5.2). These findings strongly suggest that both CEC and CMC have a basal cellular eicosanoid level. In case of a strong stimulus (for instance A23187), the amount of eicosanoids produced after the addition of the stimulating agent is quantitatively released into the surrounding medium.

CEC in situ are surrounded by albumin, present in both the vascular and interstitial space. In order to investigate the influence of this fatty acid-carrying protein on the production of eicosanoids in isolated CEC, in a subset of experiments AA complexed to $200 \mu \mathrm{M}$ albumin was administered to the incubation medium. The presence of albumin significantly altered the stimulating effect of exogenous AA in endothelial eicosanoid formation (fig. 5.5c). This effect was most noticeable at AA concentrations up to $40 \mu \mathrm{M}$, because no release of eicosanoids could be observed below this level. In the absence of albumin AA probably binds to cellular structures and substantially increases the availabilty of AA for enzymatic conversion. When albumin is present, the majority of AA is most likely kept in solution in the surrounding medium. In view of the fact that the AA concentration in arterial plasma is less than $20 \mu \mathrm{M}(40,42)$, the conclusion can be drawn that under physiological conditions extracellular AA is no strong stimulus for endothelial eicosanoid production. However, in hearts with compromised perfusion, the content of $\mathrm{AA}$ in the ischemic myocardium significantly increases $(8,12,42)$. In this respect, it is interesting to note that under these circumstances the significantly elevated tissue AA content induces only limited amounts of eicosanoids, probably due to compartimentalization of AA in irreversibly damaged heart cells (39).

\subsection{SUMMARY}

Despite a number of attempts to identify the cellular site of production of eicosanoids in cardiac tissue, no agreement exists about the cell type responsible for the production of eicosanoids in the heart. The capacity of various cell types, isolated from adult rat heart, to synthesize eicosanoids was studied. Cells were routinely incubated in the presence of the $\mathrm{Ca}^{2+}$ ionophore $\mathrm{A} 23187(10 \mu \mathrm{M})$ and exogenous arachidonic acid (AA, $80 \mu \mathrm{M}$ ). The release of total eicosanoids in the incubation medium amounted to $23.3 \pm 4.5$ and $2.0 \pm 0.4 \mathrm{nmol} / \mathrm{mg}$ cellular 
protein per $30 \mathrm{~min}$ in subcultivated CEC and CFLC, respectively. The release in isolated CMC remained below the detection limit of the HPLC assay technique applied $(<0.00075 \mathrm{nmol} /$ incubation). The production rate of eicosanoids in subcultivated CEC was highest in the first 5 to $10 \mathrm{~min}$ of incubation and declined thereafter, suggesting deactivation of the enzymes involved.

$\mathrm{PGE}_{2}, \mathrm{PGF}_{2 \alpha}, 12-\mathrm{HHT}, 11-$ and 15-HETE and $\mathrm{TxB}_{2}$ were the main eicosanoids released by endothelial cells. 6-Keto-PGF $1 \alpha$, the stable degradation product of prostacyclin, contributed relatively little to the total amount of eicosanoids formed by CEC. CFLC released predominantly $\mathrm{PGE}_{2}$ and 6 -keto-PGF 10 and to a lesser extent 12-HHT and 15-HETE. Neither CEC nor CFLC released leukotrienes. With the use of a radioimmunoassay technique cardiomyocytes were found to release $0.002 \pm 0.0001 \mathrm{nmol}$ of the stable prostacyclin-derivate 6-keto$\mathrm{PGF}_{1 \alpha} / \mathrm{mg}$ cellular protein per $30 \mathrm{~min}$. In comparison CEC and CFLC released $0.12 \pm 0.09$ and $0.62 \pm 0.20 \mathrm{nmol} 6-$ keto- $\mathrm{PGF}_{\mathrm{l \alpha}} / \mathrm{mg}$ cellular protein per $30 \mathrm{~min}$, respectively.

Since CEC were the main eicosanoid producing cells in vitro, the effect of the extracellular stimulants AA and A23187 was studied in more detail in this cell type. Exogenous AA $(80 \mu \mathrm{M})$ was required to fully stimulate endothelial eicosanoid formation. Addition of A23187 stimulated the release of eicosanoids at AA concentrations below $80 \mu \mathrm{M}$. No additional effect was observed at higher extracellular levels of AA. Because exogenous AA is supplied to endothelial cells in vivo complexed to albumin, the effect of this protein on endothelial eicosanoid release was studied. Extracellular albumin $(200 \mu \mathrm{M})$ was found to reduce the stimulatory effect of AA and A23187 especially at low levels of AA.

The effect of the more physiological stimuli histamine and bradykinin was studied in CEC and in CMC in comparison with A23187. Histamine and bradykinin did not significantly increase the release of 6-keto- $\mathrm{PGF}_{1 \alpha}$ or $\mathrm{PGE}_{2}$ in $\mathrm{CMC}$. Only histamine gave rise to a slight but significant higher release of 6 -keto- $\mathrm{PGF}_{1 \alpha}$ in CEC. The cellular content of 6-keto-PGF $1 \alpha$ and $\mathrm{PGE}_{2}$ was not influenced by addition of bradykinin, histamine or A23187 to the incubation medium.

\subsection{REFERENCES}

1 A humada GG, Sobel BE, Needleman P (1980) Synthesis of prostaglandins by cultured rat heart myocytes and cardiac mesenchymal cells. J Mol Cell Cardiol 12: 685-700

2 Bolton HS, Chanderbhan R, Bryant RW, Bailey JM, Weglicki WB, Vahouny, GV (1980) Prostaglandin synthesis by adult heart myocytes. J Mol Cell Cardiol 12: 1287-1298

3 Boutherin-Falson O, Blaes N (1989) Decreased prostacyclin production by human umbilical vein endothelial cells cultured with endothclial cell growth factor and heparin. Thromb Res 54: 487-492

4 Bradford M M (1976) A rapid and sensitive method for the quantitation of microgram quantities of protein utilizing the principle of protein-dye binding. Anal Biochem 72: 248-254

5 Bruggeman CA, Debie WHM, Muller AD, Schutte B, Van Dam-Mieras MCE (1988) Cytomegalovirus alters the Von Willebrand factor content in human endothelial cells. Thromb Haemost 59: 264-268 
6 Carter TD, Pearson JD (1992) Regulation of prostacyclin synthesis in endothelial cells. News In Physiol Sci 7: 64-69

7 Chaudhari A, Pedram A, Kirschenbaum MA (1989) $\mathrm{PGI}_{2}$ is not a major prostanoid produced by cultured rabbit renal microvascular endothelial cells. Am J Physiol 256: F266-F273

8 Chien KR., Han A, Sen A, Buja LM, Willerson JT (1984) Accumulation of unesterified arachidonic acid in ischemic canine myocardium. Circ Res 54: 313-322

9 Chung-Wclch N, Shepro D, Dunham B, Hechtman HB (1988) Prostacyclin and prostaglandin $E_{2}$ secretions by bovine pulmonary microvessel endothelial cells are altered by changes in culture conditions. J Cell Physiol 135: 224-234

10) Colc OF, Fan T-PD, Lewis GP (1986) Release of eicosanoids from cultured rat aortic endothelial cells; studies with arachidonic acid and calcium ionophore A23187. Cell Biol Int Rep 10: 407-413

11 Cole O, Lcwis GP (1989) Prostanoid production by rat aortic endothelial cells by bradykinin and histamine. Eur J Pharmacol 169; 307-312

12 Das DK, Engelman RM, Rousou JA, Breyer RH, Otani H, Lemeshow S (1986) Role of membrane phospholipids in myocardial injury induced by ischemia and reperfusion. Am J Physiol 251: H71-H79

13 De Deckere EAM, Nugteren DH, Ten Hoor F (1977) Prostacyclin is the major prostaglandin released from the isolated rabbit and rat heart. Nature 268: 160-163

14 Diglio CA, Grammas P, Giacomelli F, Wiener J (1988) Rat heart-derived endothelial and smooth muscle cell cultures: isolation, cloning and characterization. Tissue Cell 20:477-492

15 Engels W, Kamps M, Lemmens PJMR, Van der Vusse GJ, Reneman RS (1988) Determination of prostaglandins and thromboxane in whole blood by high-performance liquid chromatography with fluorimetric detection. J Chromatogr 427: 209-218

16 Engels W, Van Bilsen M, De Groot JM, Lemmens PJMR, Willemsen PHM, Reneman RS, Van der Vusse GJ (1990) Ischemia and reperfusion induced formation of eicosanoids in isolated rat hearts. Am J Physiol 258: H1865-H1871

17 Engels W, Van Bilsen M, Van der Vusse GJ, Willemsen PHM, Coumans WA, Kamps MAF, Endert J, Reneman RS (1987) Influence of intracellular $\mathrm{Ca}^{2+}$ overload in eicosanoid synthesis of the myocardium. Basic Res Cardiol 82 (suppl 1): 245-252

18 Escoubet B, Griffaton G, Samuet J-L, Lechat P (1986) Calcium antagonists stimulate prostaglandin synthesis by cultured rat cardiac myocytes and prevent the effects of hypoxia. Biochem Pharmacol 35: 4401-4407

19 Gerritsen ME (1987) Eicosanoid production by the coronary microvascular endothelium. Fed Proc 46: 47-53

20) Gerritsen ME, Cheli CD (1983) Arachidonic acid and prostaglandin endoperoxide metabolism in isolated rabbit and coronary microvessels and cultivated coronary microvessel endothelial cells. J Clin Invest 72: 1658-1671

21 Griesmacher A, Weigel G, Schreiner W, Muller MM (1989) Thromboxane A2 generation by human umbilical endothelial cells. Thromb Res 56: 611-623

22 Hasegawa N, Yamamoto M, Yamamoto K (1988) Stimulation of cell growth and inhibition of prostacyclin production by heparin in human umbilical vein endothehal cells. J Cell Physiol 137: $603-607$

23 Hohl CM. Rósen P (1987) The role of arachidonic acid in rat heart cell metabolism. Biochim Biophys Acta 921: 356-363

24 Hsuch W. Needleman P (1978) Sites of lipase activation and prostaglandin synthesis in isolated, perfused hearts and hydronephrotic kidneys. Prostaglandins 16: 661-681

25 Ingerman-Wojenski, CM, Silver MJ (1988) Prostacyclin synthesis by endothelial cells from human umbilical veins: effect of cumulative population doublings. Prostaglandins 36: 127-138

26 Karmazyn M (1986) Contribution of prostaglandins to reperfusion-induced ventricular failure in isolated rat hearts. Am J Physiol 25l: H133-H140

27 Karmazyn M. Dhalla NS (1983) Physiological and pathophysiological aspects of cardiac prostaglandins, Canad J Pharmacol 61: 1207-1225

28 Keller AM, Clancy RM, Barr ML, Marboe CC, Cannon PJ (1988) Acute reoxygenation injury in the isolated rat heart: role of resident cardiac mast cells. Circ Res 63: 1044-1052

29 Linssen MCJG, Willemsen PHM, Heynen VVTh, Van der Vusse GJ (1992) Arachidonic acid incorporation in cardiomyocytes, endothelial cells and fibroblast-like cells isolated from adult rat heart. Mol Cell Biochem 116: 203-209 
30 Mattila P. Renkonen! R (1989) Gamma-interferon induces prostacyclin and prostaglandin but not lipoxygenase product synthesis in rat endotheilal cells. Immunol Lett 22: 59-64

31 Moore SM, Spector AA, Hart MN (1988). Eicosanoid synthesis in cerebromicrovascular endothelium. Am J Physiol 254: C37-C44

32 Needleman P. Turk J, Jakschik BA, Morrison AR, Lefkowith JB (1986) A rachidonic acid metabolism. Ann Rev Biochem 55: 69-102

33 Piper HM, Probst I, Schwartz P. Hütter FJ, Spieckermann PG (1982) Culturing of calcium stable adult cardiac myocytes. 3 Mol Cell Cardiol 14: 397-412

34 Revryak. GE, Buja LM, Chien KR, Campbell WB (1990) Reduced arachidonate metabolism in ATP-depleted myocardial cells occurs early in cell injury. Am J Physiol 259: H582-H591

35 Revtyak GE., Johnson AR', Campbell WB (1988) Cultured bovine coronary arterial endothelial cells synthesize HETE's and prostacyclin. Am J Physiol 254: C8-CI9

36 Simmet T, Peskar BA (1986) Eicosanoids and the coronary circulation. Rev Physicl Biochem Pharmacol 104: 1-64

37 Taylor L, Foxall T, Auger K. Heinsohn C, Polgar P (1987) Comparison of prostaglandin synthesis by endothelial cells from bloodvessels originating in the rat, baboon, calf and human. Atherosclerosis $65: 227-236$,

38 Tokungana O, Watanabe T (1987) Properties of endothelial cell and smooth muscle cell cultured in ambient pressure. In Vitro Cell Dev Biol 23: 528-534

39 Van Bilsen M, Engels W, Van der Vusse GJ. Reneman RS (1989) Significance of myocardial eicosanoid production. Mol Cell Biochem 88: 113-121

40 Van der Vusse GJ, Roemen THM, Flameng W, Reneman RS (1983) Serum-myocardium gradients of non-esterified fatly acids in dog, fat and man. Biochim Biophys Acta 752: $361-370$

41 Van der Vusse GJ, Van Bilsen M, Reneman RS (1989) Is phospholipid degradation a critical event in ischemia and reperfusion-induced damage. News In Physiol Sci 4: 49.53

42 Van der Vusse GJ, Roemen THM, Prinzen FW, Coumans WÁ, Reneman RS (1982) Uptake and tissue content of fatty acids in dog myocardium under normoxic and ischemic conditions. Circ Res 50: 538-546

43 Weber DR, Stroud ED, Prescott SM (1989) Arachidonate metabolism in cultured fibroblasts derived from normal and inlarcted canine heart. Circ Res 65: 671-683

44 Zijlstra FJ, Vincent JE (1984) Determination of leukotrienes and prostaglandins in $\left[{ }^{14} \mathrm{Cl}\right.$ arachidonic acid labelled human lung tissue by high performance liquid chromatography and radioimmunoassay. J Chromatogr $311: 39-50$ 



\section{CHAPTER 6}

ARACHIDONIC ACID INCORPORATION IN CARDIO-
MYOCYTES, ENDOTHELIAL CELLS AND FIBROBLAST-
LIKE CELLS ISOLATED FROM ADULT RAT HEART

Part of this chapter is published in

Linssen MCJG, Willemsen PHM, Heijnen VVTh, Van der Vusse GJ (1992) Arachidonic acid incorporation in cardiomyocytes, endothelial cells and fibroblast-like cells isolated from adult rat heart. Mol Cell Biochem 116: 203209. 


\subsection{INTRODUCTION}

Phospholipids are the fundamental constituents of cardiac membranes and play an important role in the preservation of cellular integrity. Under pathophysiological conditions cellular integrity can become compromised with concomitant physicochemical alterations in membrane phospholipids (17).

In cardiac tissue phospholipids are present in a variety of subclasses, such as phosphatidylcholine, phosphatidylethanolamine, phosphatidylinositol and phosphatidylserine, each with a different fatty acid composition. The fatty acid arachidonic acid (AA) comprises about $15 \%$ of the total fatty acid content in rat heart and the majority of AA is incorporated in the phospholipid (PL) fraction $(96.4 \%)$, whereas $3.5 \%$ is found in the triacylglycerol (TG) pool and less than $0.1 \%$ is present as unesterified fatty acid (FA, refs. 14,15 ).

Alterations in myocardial membrane structure and function play most likely a crucial role in the development of myocardial cell injury during ischemia and reperfusion (1.5). Several hypotheses have been proposed to explain the mechanism of cell death. Lack of energy and intracellular accumulation of calcium have been proposed to be important factors in the development of irreversible tissue damage upon ischemia followed by reperfusion (7). The loss of control of the cytoplasmic calcium concentration could be attributed to the observed decline in energy status of the cell. This could lead to a reduction in the calcium-pumping activity of the sarcolemma, mitochondria and sarcoplasmic reticulum and possibly to partial opening of the slow calcium channels and other non-specific pores. Then the rise in calcium could cause a higher enzymatic activity of calcium-dependent enzymes such as phospholipases. As shown in previous studies, the AA content rises after $30 \mathrm{~min}$ ischemia suggesting disturbed phospholipid homeostasis during the ischemic insult $(2,14,17,18,19)$. Changes in the content and composition of membrane phospholipids may play an important role in the transition from reversible to irreversible cell injury. As a result of stress on the membrane by osmotic pressure or contracture of the myofibrils, proper attachment of the membrane to the cytoskeleton can be further impaired causing disruption of the membrane (6). Free radicals can cause additional damage of the membrane by attacking the unsaturated bonds in the fatty acyl chains of membrane phospholipids.

Information on the incorporation and release of AA is important to delineate the changes in phospholipids at the point of reversible to irreversible cell damage. Since the heart is composed of different cell types, e.g. endothelial cells, cardiomyocytes, and fibroblasts, inter-cellular differences in phospholipid and AA homeostasis may be anticipated. Knowledge about the AA incorporation under control conditions in the different cell types is still incomplete and needs further investigation. This knowledge is required to explain in a proper fashion changes in AA metabolism during early events of cell damage. For that reason the aim of this study was to get more insight into the incorporation of AA in the cellular phospholipid pool under normoxic conditions. To this end $\left[{ }^{3} \mathrm{H}\right]-\mathrm{AA}$ was 
incorporated in cardiomyocytes (CMC), endothelial cells (CEC) and fibroblastlike cells (CFLC) isolated from adult rat heart. Its cellular distribution was analyzed by autoradiography at the light and electron microscopic level. The effect of the duration of the incubation and the concentration of AA on incorporation of labeled AA in the phospholipid and triacylglycerol pools was monitored by biochemical measurements.

\subsection{METHODS}

\section{lsolation and culturing of cells}

CEC, CFLC and CMC were isolated as described in chapter 2. CMC were kept only 20 hours in culture after isolation; then the attached CMC were still rod shaped and excluded trypan blue. The non-attached cells were washed away. CEC and CFLC were grown under tissue culture conditions. In the experiments described, CEC and CFLC between passage 2 and 6 were used.

\section{Labeling for autoradiography}

Before labeling the cells were washed with Hanks' Balanced Salt Solution with 10 mM HEPES (HBSS). [5,6,8,9,11,12,14,15-3 $\mathrm{H}]$-AA was dissolved in ethanol in a concentration of $5 \mu \mathrm{M}$ and was diluted in HBSS to $10 \mathrm{nM}$ before the experiment.

For autoradiography $0.5 \mathrm{ml}$ of HBSS and $1 \mu \mathrm{Ci}, 10 \mathrm{nM}\left[{ }^{3} \mathrm{HI}\right.$-AA was added to the cells grown on coverslips and incubations were performed for $30 \mathrm{~min}$ at $5 \% \mathrm{CO}_{2}$, $95 \%$ air, in a $37^{\circ} \mathrm{C}$ stove. For controls, cells were incubated with HBSS alone under further identical conditions as the incubations with $\left[{ }^{3} \mathrm{H}\right]$-AA. Thereafter cells were fixed in $2 \%$ glutaraldehyde with $2 \%$ tannine and post fixed in $1 \%$ osmium tetroxide, stained en bloc with $2 \%$ uranyl acetate, dehydrated and embedded in epon. For light microscopy ultrathin sections on glass slides were covered with Ilford $\mathrm{K} 2$ emulsion according to the the dipping technique and exposed for 3-6 days. Then the emulsion was developed with D.76, 1:1 diluted, for $4 \mathrm{~min}$ and fixed in X55 profix, 1:8 diluted, for $5 \mathrm{~min}$. After washing with water for $20 \mathrm{~min}$ and drying, the coupes were stained with toluidine blue and examined under the light microscope.

For electron microscopic autoradiography ultrathin sections were mounted on collodion (2\% in amyl-acetate) or formvar coated gilded grids of 200 mesh. The specimens were stained with lead citrate and coated with a thin layer of of carbon by evaporation. Then mounted on corks (about $1 \mathrm{~cm}$ in diameter) by the use of double-sided tape. The autoradiographic emulsion Ilford $L A$ was mounted on the corke-borne specimens with the wire loop technique. After 30 to 150 days of exposure the emulsion was developed with Microdol $X$ for $3 \mathrm{~min}$, rinsed in distilled water for $20 \mathrm{sec}$, fixed in $30 \%$ thiosulfate for $4 \mathrm{~min}$, extensively rinsed in water, and finally dried before examination under the electron transmission microscope (CM 10, Philips). 


\section{Laheling of endogenous lipid pool}

For biochemical analysis of AA incorporation in the cellular lipid pool $0.5 \mathrm{ml}$ HBSS containing $\left.\left.1 \mu \mathrm{Ci}\right|^{3} \mathrm{H}\right]$-AA, with or without additional unlabeled AA $(1 \mu \mathrm{M}$ or $10 \mu \mathrm{M}$ ), was administered to the cells on $3.5 \mathrm{~cm}$ diameter dishes. Incubations were performed for 30 or 90 min under $5 \% \mathrm{CO}_{2}, 95 \%$ air, at $37^{\circ} \mathrm{C}$. Aspecific binding of $\left|{ }^{3} \mathrm{H}\right|$-AA to the dishes was measured by incubating control dishes without cells under similar conditions. After washing with PBS, cells and controls were collected by scraping in $0.25 \mathrm{ml}, 4^{\circ} \mathrm{C}$ PBS and additional washing of the dish was performed with $0.25 \mathrm{ml}$ PBS.

The lipids were extracted from the $500 \mu \mathrm{l}$ (cell) homogenates in $9.5 \mathrm{ml}$ chloroform/methanol ( $2: 1$, by vol) containing $0.01 \%$ butylated hydroxy toluene according to Folch (4). The lipid classes were separated by thin layer chromatography (TLC) using plates coated with silicagel (Kieselgel 60). A mixture of fatty acids (FA), triacylglycerols (TG) and phospholipids (PL) was used as external standard. The plates were predeveloped with chloroform/methanol/acetic acid/water (10:10:1:1, by vol) until the solvent front had moved $1 \mathrm{~cm}$ from its origin. After drying, the plates were further developed with petroleumether/diethylether/acetic acid/water (120:25:1.5, by vol). The lanes with the lipids standards were visualized with UV light after spraying with rhodamine $\mathrm{G}$. Than comigrated spots on the parallel lanes were scraped from the plate and counted in a liquid scintillation counter (Beckman LS 3801). For these experiments protein was determined from parallel dishes according to Bradford (1).

Determination of the endogenous fatty acid, triacylglycerol and phospholipid pool

For analysis of the quantity of cellular FA, TG, PL and the amount of AA present in these pools in the different cell types, in a subset of experiments lipids were extracted from homogenates of cells with hexane/isopropanol according to Rodriquez-Vico et al. (13). The several lipid pools were separated by TLC as described above, scraped from the plates, methylated and quantified by gas chromatography as described previously (16). The protein content in the pelleted residual fraction was dissolved and determined by the standard Lowry method (9).

\section{Materials}

Unless otherwise stated all chemicals were obtained from Merck (Darmstadt, FRG). $\left[5,6,8,9,11,12,14,15-{ }^{3} \mathrm{H}\right] \cdot \mathrm{AA}(209.6 \mathrm{Ci} / \mathrm{mmol})$ was purchased from Amersham International (Buckinghamshire, UK), Ilford K2 and L4 from Ilford Ltd. (Mobberly Cheshire, UK), developers D.76 and Microdol X from Kodak (Chalon s./Saone, France), the fixative X 55 profix from Amaloco (Ommen, The Netherlands). The gilded grids were obtained from Agar Scientific (Stansted, UK). 


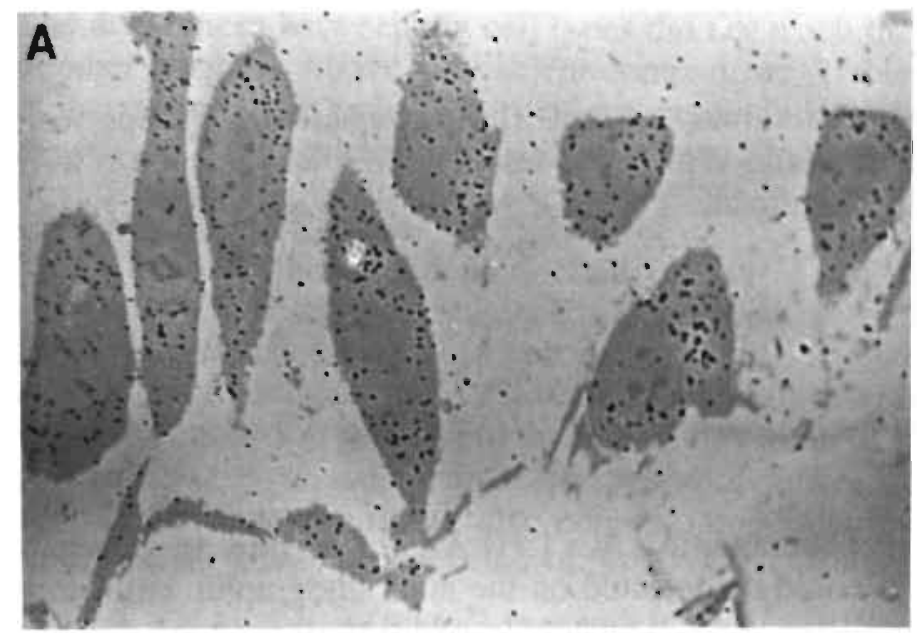

Figure 6.1. Light microscopic photographs of isolated rat heart cells after incorporation of 0.01 $\left.\left.\mu \mathrm{M}\right|^{3} \mathrm{H}\right]$-arachidonic acid for 30 min and exposure to autoradiographic emul. sions.

A: endothelial cells.

B: fibroblast-like cells.

C: cardiomyocvies.

Bar represents $10 \mathrm{\mu m}$.
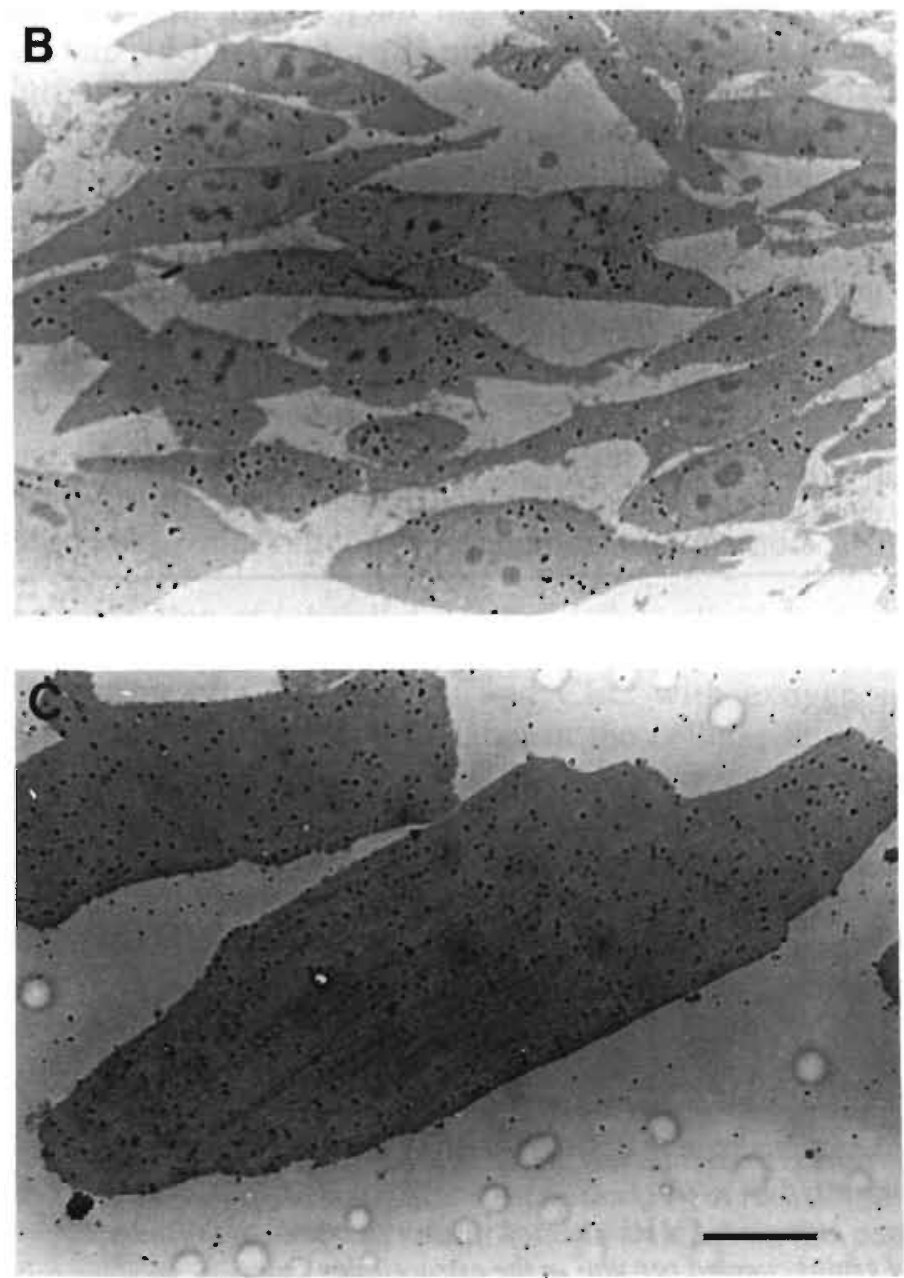


\section{Statistics}

The data are presented as mean values \pm SD. Differences between groups were tested with the nonparametric Mann-Whitney U test. P values less than 0.05 were considered to be statistically significant.

\subsection{RESULTS}

Light microscopic autoradiographic analysis of $\left[{ }^{3} \mathrm{H}\right]-A A$ incorporation in isolated cells

When isolated cells were incubated with $1 \mu \mathrm{Ci}\left[{ }^{3} \mathrm{H}\right]$-AA for $30 \mathrm{~min}$, in general a significant number of grains could be detected on the autoradiographic emulsions after 3 to 6 days of exposure (figs. 6. la, b and c). In addition, the morphology of the cells was well preserved as seen under the light microscope. In CEC and CFL.C the nuclear compartment was very well visible (figs. 6.la and b), and the lined up myofibrils, characteristic for striated muscle cells including cardiomyocytes, were clearly present (fig. 6.1c).

The localization in the cytoplasmic extranuclear compartment (including intracellular membranes and plasmalemma) was very prominent. When the number of grains were counted in the cells under investigation, the density of grains amounted to $0.30 \pm 0.12,0.15 \pm 0.06$ and $0.20 \pm 0.10$, grains per square $\mu \mathrm{m}$ cytoplasmic surface area of CEC, CFLC and CMC, respectively.

Table 6.1. Light microscopic autoradiographic analysis of different cell types, isolated from adult rat heart, after $30 \mathrm{~min}$ incorporation of $\left.1 \mu \mathrm{Ci}, 0.01 \mu \mathrm{M}{ }^{3} \mathrm{H}\right]-\mathrm{AA}$. Controls were incubated in the absence of labeled AA.

\begin{tabular}{llcc}
\hline cell type & condition & \# cells & $\#$ grains $/ \mu \mathrm{m}^{2}$ \\
\hline \multirow{2}{*}{ CEC } & {$\left[{ }^{3} \mathrm{H}\right]-\mathrm{AA}$} & 45 & $0.30 \pm 0.12$ \\
& control & 22 & $0.005 \pm 0.007$ \\
\multirow{2}{*}{ CFLC } & ['H]-AA & 15 & $0.15 \pm 0.06$ \\
& control & 10 & $0.002 \pm 0.003$ \\
CMC & ['HI-AA & 24 & $0.20 \pm 0.10$ \\
& control & 20 & $0.006 \pm 0.001$ \\
\hline
\end{tabular}

CEC, CFLC and CMC refer to endothelial cells, fibroblast-like cells and cardiomyocytes, respectively. $\left[{ }^{3} \mathrm{H}\right]$-AA to $\left[{ }^{3} \mathrm{H} /\right.$-arachidonic acid. Data are presented as mean values $\pm S D$ and are expressed as number of grains per $\mu^{2}$ cytoplasm, corrected for the number of grains counted per $\mathrm{um}^{2}$ in the extracellular space. 
The differences between the cell types did not reach the level of significance. The number of grains above the nuclear compartment (table 6.1, figs. 6.1a and b) was in the range of the grain density of the extracellular space. On the average a grain density of 0.01 grains $/ \mu \mathrm{m}^{2}$ colild be counted in the extracellular space (see also figs. 6.1a, b and c).

The values of the above mentioned cellular grain density were obtained by analyzing 15 to 45 individual cells. Considerable differences (on the order of $50 \%$ ) were observed between cell preparations incubated on different days. Figs. $6.1 \mathrm{a}, \mathrm{b}$ and $\mathrm{c}$ indicate that within one preparation also inter-individual differences in grain density are present. In some experiments sequential coupes were made of one cell. After covering these coupes with autoradiographic emulsion, using appropriate exposure times, also coupe-to-coupe variations were detectable. The fatter variation was on the order of $30 \%$.

Electron microscopic autoradiographic analysis of $\left[{ }^{3} \mathrm{H}\right]-\mathrm{AA}$ incorporation in isolated $C E C$ and $C M C$

For a further ultrastructural observation of the distribution of $\left[{ }^{3} \mathrm{H}\right]-\mathrm{AA}$, electronmicroscopic autoradiographs were developed and qualitatively analyzed. The CMC showed a clear cytoplasmic labeling (fig. 6.2a, b). Mitochondria as well as the lipid droplets seemed to contain labeled material. Only after overexposure of 5 months, sequestration of $[3 \mathrm{H}]-\mathrm{AA}$ in the sarcolemma and in its close vicinity (fig. 6.2b) became visible. The overexposed specimens of CMC showed that there was a clear labeling of the lipid droplets, mitochondria and probably the nuclear membrane.

The CEC also demonstrated a perinuclear, cytoplasmic labeling (fig. 6.2c, d). Lipid droplets were less frequent or hardly detectable. $\left[{ }^{3} \mathrm{H}\right]-\mathrm{AA}$ was found to be associated with both the plasmalemma and the nuclear membrane (fig. 6.2c, d).

Incorporation of labeled AA in the cellular lipid pool (biochemical analysis)

Incubation of $\mathrm{CMC}, \mathrm{CFCL}$ and $\mathrm{CEC}$ with exogenous $\left[{ }^{3} \mathrm{H}\right]-\mathrm{AA}$ resulted in a significant incorporation of label in the cellular lipid pool. In general 600-8000, $200-2000,1500-15000 \mathrm{dpm}\left[{ }^{3} \mathrm{H}\right]-\mathrm{AA} / \mathrm{mg}$ cellular protein were found to be sequestered by CMC, CFLC and CEC, respectively. The incubation conditions were $0.01,10$, or $10 \mu \mathrm{M} \mathrm{AA}$ for 30 or $90 \mathrm{~min}$. In these experiments the amount of $\left[{ }^{3} \mathrm{H}\right]-\mathrm{AA}$ incorporated in the total cellular lipid pool was only slightly influenced by the extracellular AA concentration and incubation time. The incorporated quantities correspond with $10-25 \%$ of the amount of $\left[{ }^{3} \mathrm{H}\right]-\mathrm{AA}$ present in the incubation medium.

The labeling of the FA fraction was low, i.e. in the range of the aspecific binding of $\left[{ }^{3} \mathrm{H}\right]-\mathrm{AA}$ to the dishes. The labeled AA was mainly incorporated in the cellular phospholipid and triacylglycerol pool. At low AA concentrations $(0.01 \mu \mathrm{M})$ CEC and CFLC sequestered predominantly $\left[{ }^{3} \mathrm{H}\right]-\mathrm{AA}$ in the phospholipid pool. 

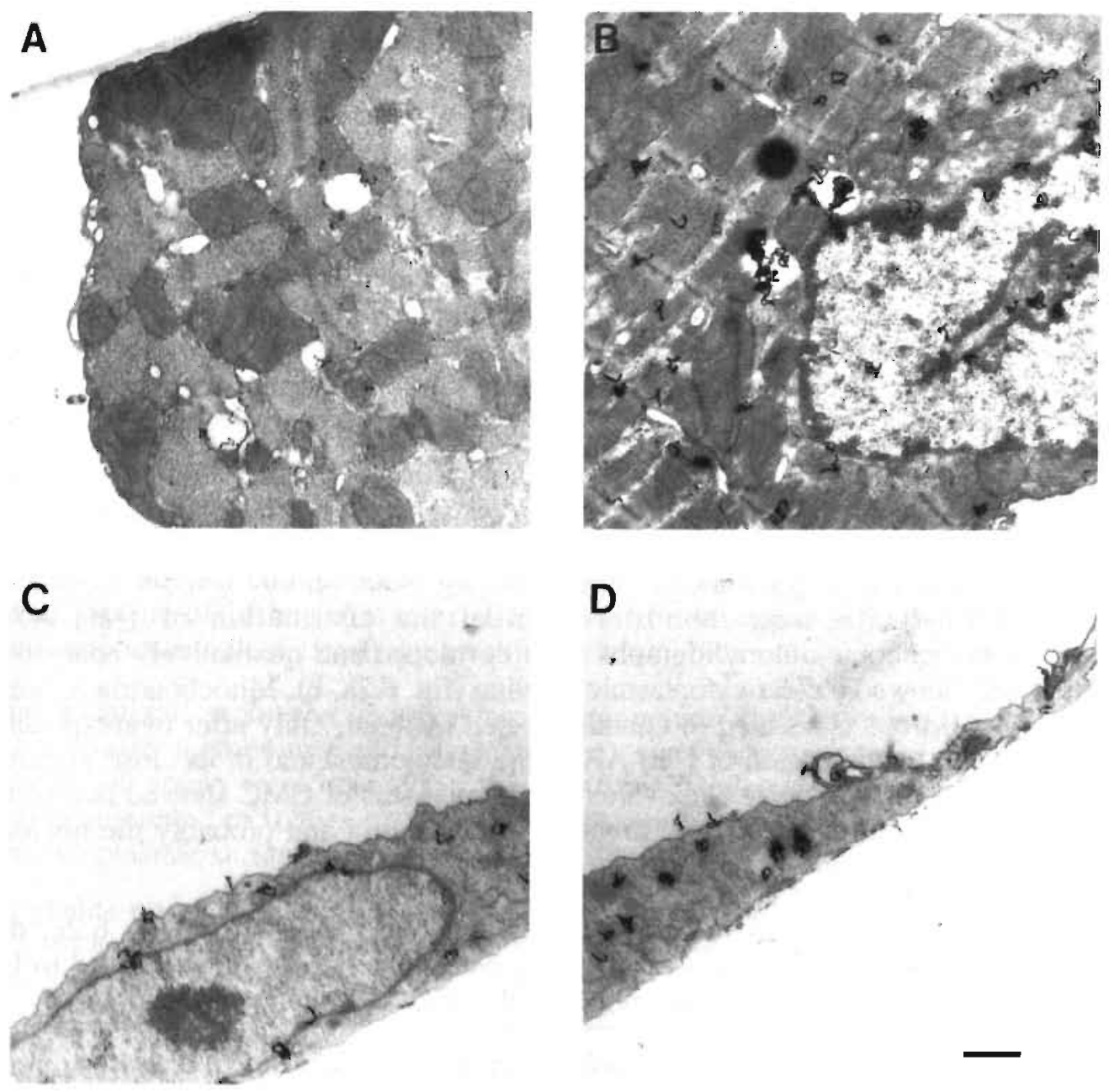

Figure 6.2. Electron micrographs isolated rat heart cells, after incorporation of $0.01 \mu \mathrm{M}\left[{ }^{3} \mathrm{H} /\right.$-AA for 30 min and exposure to autoradiographic emulsion. A: cardiomyocyle (CMC) after two months of exposure. B: CMC after 5 months of exposure. $C$ and D: cardiac endothelial cell after 5 months of exposure. Bar represents 1 um.

The proportion of labeled AA incorporated in triacylglycerols was small, resulting in a high phospholipid/triacylglycerol ratio (table 6.2 ). When the incubation time was extended from 30 to $90 \mathrm{~min}$ a relative change of deposition of label could be observed in the direction of the triacylglycerols (decline in phospholipid/triacylglycerol ratio). When the extracellular AA concentration was increased from $0.01 \mu \mathrm{M}$ to $1.0 \mu \mathrm{M}$, in CEC and CFLC the preference of the phospholipid pool as site of AA incorporation was less marked and incorporation in the triacylglycerol fraction became more prominent. In general, at 1 and 10 
$\mu \mathrm{M}$ AA, longer incubation times did not decrease the ratio phospholipid/triacylglycerol $\left(\left[{ }^{3} \mathrm{H}\right]-\mathrm{AA}\right)$ in CEC and CFLC, but tended to increase this ratio (even significant, from $4.9 \pm 1.0$ to $7.2 \pm 0.9$, in $\mathrm{CEC}$ at $1 \mu \mathrm{M} \mathrm{AA}$ ). In contrast to CEC and CFLC, in CMC at 0.01 and $1 \mu \mathrm{M} \mathrm{AA}$, no significant differences could be observed between the phospholipid and the triacylglycerol pool with respect to the amount of $\left[{ }^{3} \mathrm{H}\right]-\mathrm{AA}$ incorporated, as similar quantities of label were incorporated in the phospholipid and triacylglycerol pool during 30 and 90 min of incubation (table 6.2). Raising the extracellular AA concentration to $10 \mu \mathrm{M}$ AA promoted the incorporation of $\left[{ }^{3} \mathrm{H}\right]-\mathrm{AA}$ in cellular triacylglycerols. Under this condition the triacylglycerol pool was found to be the preferred site of deposition of label as indicated by a $\left[{ }^{3} \mathrm{H}\right]-\mathrm{AA}$ phospholipid/triacylglycerol ratio significantly lower than 1 (table 6.2).

Table 6.2. The $\left[{ }^{3} \mathrm{H}\right]$-AA phospholipid/triacylglycerol ratio in $\mathrm{CEC}, \mathrm{CFLC}$ and $\mathrm{CMC}$ after 30 and $90 \mathrm{~min}$ of incubation. The concentration of added $\mathrm{AA}$ varied from 0.01 to 10 $\mu \mathrm{M}$.

\begin{tabular}{|c|c|c|c|c|}
\hline \multirow[t]{2}{*}{ cell type } & \multirow[t]{2}{*}{$\mathrm{AA}(\mu \mathrm{M})$} & \multirow[t]{2}{*}{$\mathrm{n}$} & \multicolumn{2}{|c|}{ time (min) } \\
\hline & & & 30 & 90 \\
\hline \multirow[t]{3}{*}{ CEC } & 0.01 & 4 & $31.1 \pm 28.1$ & $15.1 \pm 7.9$ \\
\hline & 1 & 6 & $4.9 \pm 1.0^{d}$ & $7.2 \pm 0.9 a, d$ \\
\hline & 10 & 8 & $1.0 \pm 0.4 d . e$ & $1.4 \pm 0.5 d, e$ \\
\hline \multirow[t]{3}{*}{ CFLC } & 0.01 & 4 & $158.7 \pm 32.7 b$ & $49.4 \pm 30.8 a$ \\
\hline & 1 & 4 & $17.0 \pm 4.8^{b . d}$ & $18.0 \pm 1.6^{b . d}$ \\
\hline & 10 & 4 & $2.3 \pm 0.4 b . d, e$ & $2.7 \pm 0.5 b, d, e$ \\
\hline \multirow[t]{3}{*}{$\mathrm{CMC}$} & 0.01 & 6 & $0.7 \pm 0.4 b, c$ & $0.9 \pm 0.3 b, c$ \\
\hline & 1 & 6 & $0.8 \pm 0.3 b, c$ & $1.3 \pm 0.7 b . c$ \\
\hline & 10 & 6 & $0.3 \pm 0.1 b . c, d, e$ & $0.4 \pm 0.3 b, c . e$ \\
\hline
\end{tabular}

CEC, CFLC and CMC refer to cardiac endothelial cells, fibroblast-like cells and cardiomyocytes, respectively; AA to arachidonic acid; $n$ to the number of experiments. Data are depicted as mean values $\pm S D$. Differences between groups were lested with the nonparametric Mann-Whitney $U$ test, $p$ values $<0.05$ were considered to be statistically significant; a) significant different from the corresponding value at $30 \mathrm{~min}$; b) significant different from the corresponding value in $C E C_{;}$c) significam different from the corresponding value in $C F L C$; d) significant differem from the corresponding value obtained at $0.01 \mu M A A$ in the same cell type; e) significant different from the corresponding value obtained at $1 \mu M A A$ in the same cell type. 
The content of fatty acids, triacylglycerols and phospholipids in isolated cells

Since differences in incorporation of labeled AA in the endogenous lipid pools between the various cell types can be caused by differences in pool size of fatty acids, triacylglycerol and phospholipids, the content of these lipid fractions was analyticatly assessed (table 6.3a). In addition, the proportion of AA in the fatty acid, triacylglycerol and phospholipid pool was monitored (table 6.3b).

The phospholipid content in the three cell types was on the order of 250-350 nmol fatty acyl chains per mg cellular protein, corresponding with about $125-175 \mathrm{nmol}$ phospholipid per $\mathrm{mg}$ protein. No significant differences could be observed between the various cell types. In contrast, the size of the triacylglycerol pool was significantly higher in CMC than in CEC and CFLC. The content in the latter two cell types was mutually not significantly different. Also the FA content differed between the cell types studied, in CEC it was twice as high than in CFLC and $\mathrm{CMC}$. The size of the unlabeled AA fraction in the cellular FA pool was not different in the three cell types. Interestingly, the content of unlabeled AA in the cellular phospholipid pool was found to be twice as high in CMC than in CEC and CFLC (table 6.3b), despite similar total phospholipid levels in these cells. The content of AA in the cellular triacylglycerol pool was higher in CMC than in the other two cell types, as could be expected on the basis of the total triacylglycerol content. As a consequence, the ratio of AA present in the phospholipid over the triacylglycerol pool was significantly lower in CMC (i.e. 28.2) than in CEC and CFLC (i.e. 83.9 and 98.4 , respectively).

\subsection{DISCUSSION}

The present study shows that $\left[{ }^{3} \mathrm{H}\right]-\mathrm{AA}$ added to cells isolated from adult rat hearts is readily incorporated into the cellular lipid pool.

Autoradiography at the light and electron microscopic level revealed that label was mainly present in the extranuclear space of the cell. When CMC, CEC and CFLC were incubated under comparable conditions, the number of grains per square $\mu \mathrm{m}$ cytoplasmic surface were on the same order of magnitude in the three cell types. Since [ $\left.{ }^{3} \mathrm{H}\right]$-AA is mainly incorporated in the cellular phospholipid and triacylglycerol pool (table 6.2), the grains observed do most likely reflect deposition of labeled AA in the cellular membranes and lipid droplets being the storage sites of phospholipids and triacylglycerols, respectively. Although the electron microscopic technique does not allow identification of the exact site of deposition of label unless extended statistic analysis will be performed, the present findings strongly suggest that in addition to the sarcolemmal phospholipids also phospholipids in intracellular membranes (i.e. membranes surrounding the matrix of subsarcolemmal and intrafibrillar mitochondria, and intracellular lipid droplets) have sequestered a substantial quantity of $\left[{ }^{3} \mathrm{H}\right]-A \mathrm{~A}$. Discrimination between intracellular lipid droplets and neighbouring mitochondria also requires 
extended cross-fire analysis techniques. In this regard, Miyazaki and coworkers (10, 11) observed in cultured neonatal candiomyocyles with electron microscopic autoradiography that deposition of [3H]-AA mainly occurred in mitochondrial and perimuclear membranes. In their study, the incorporation of label in the sarcolemma of nomoxic cells appeared to be minimal $(10,11)$.

Chemical analysis corroborated the notion that the extracted [3H]-AA is incorporated in the cellular phospholipid and triacylglycerol pool. The relative distribution of the labeled fatty acid over the two esterified lipid pools depended on a variety of factors such as type of cells studied, concentration of $\mathrm{AA}$ added to the incubation medium and to a lesser extent the incubation interval.

Table 6.3. The celublat faty acid content of FA, TG and PL in isolated CEC, CFLC and $C M C$ (panel $A$ ) and the content of $A A$ in the FA, TG and PL fractions of these cell types (parel B). The ratio's of the total content of PL and TG and of the amotnts of AA in these lipid pools are given as well.

A) content of fatly acyl moieties in FA, TG and PL

\begin{tabular}{lccccccc} 
cell type & $\mathrm{FA}$ & $\mathrm{n}$ & $\mathrm{TG}$ & $\mathrm{n}$ & $\mathrm{PL}$ & $\mathrm{n}$ & $\mathrm{PL} / \mathrm{TG}$ \\
\hline CEC & $7.3 \pm 3.0$ & 7 & $12.7 \pm 6.9$ & 12 & $313 \pm 65$ & 11 & 30.7 \\
CFLC & $4.0 \pm 0.6^{b}$ & 5 & $10.2 \pm 5.5$ & 9 & $274 \pm 87$ & 10 & 31.7 \\
CMC & $2.6 \pm 1.2^{b}$ & 5 & $55.3 \pm 25.8^{a}$ & 9 & $350 \pm 102$ & 7 & $8.2^{a}$
\end{tabular}

B) total amount of $A A$ in $F A, T G$ and $P L$

\begin{tabular}{lccccccc} 
cell type & $\mathrm{FA}$ & $\mathrm{n}$ & $\mathrm{TG}$ & $\mathrm{n}$ & $\mathrm{PL}$ & $\mathrm{n}$ & $\mathrm{PL} / \mathrm{TG}$ \\
\hline CEC & $0.10 \pm 0.01$ & 2 & $0.55 \pm 0.37$ & 4 & $28.7 \pm 19.4$ & 11 & 83.9 \\
CFLC & $0.15 \pm 0.04$ & 2 & $0.31 \pm 0.12$ & 5 & $29.5 \pm 15.8$ & 8 & 98.4 \\
CMC & $0.18 \pm 0.09$ & 5 & $2.27 \pm 0.53^{a}$ & 8 & $63.5 \pm 23.4 a$ & 7 & $28.2^{a}$ \\
\hline \hline
\end{tabular}

CEC, CFLC and CMC refer to cardiac endothelial cells, fibroblast-like cells and cardiomyocytes; AA to arachidonic acid; $F A$ to fatty acids; TG to triacylglycerols and PL. to phospholipids. Data are depicted as means $\pm S D$ and are expressed as nmol fatty acyl moieties per $m g$ cellular protein; $n$ refers to number of experiments. Differences between groups were tested with the nonparametric Mann-Whitney $U$ test, $p$ values $<0.05$ were considered to be statistically significant; a) significant different from the corresponding values in $C E C$ and $C F L C$; $b$ ) significant different from the corresponding value in $C E C$. 
In general, phospholipids are the preferred pool of deposition of labeled AA in CEC and CFLC when the extracellular concentration of AA is low. Apparently at higher concentrations of AA the incorporation into the phospholipid pool of the cells gets saturated and the esterification of this fatty acid into the well-know storage form of cellular fatty acids, the triacylglycerol pool is enhanced. It should be noted that the high phospholipid/triacylglycerol ratio of $\left[{ }^{3} \mathrm{H}\right]-\mathrm{AA}$ incorporated corresponds with the relative abundance of unlabeled AA in the two lipid classes (table 6.3). A marked difference was observed between CMC on the one hand and CEC and CFLC on the other. At AA concentration of $1.0 \mu \mathrm{M}$ and lower, in CMC the quantities of labeled AA sequestered in the phospholipid and triacylglycerol pools were comparable. At high AA concentration, the triacylglycerol pool was found to be the preferred site of incorporation. This is in agreement with the findings of Hohl and Rösen (5), who also demonstrated that in adult cardiomyocytes with increasing concentrations of exogenous AA, a shift occurs in cellular storage of extracted AA from phospholipids to triacylglycerols. The relatively high rate of sequestration of $\left[{ }^{3} \mathrm{H}\right]$-AA in the cardiomyocytal triacylglycerol pool can partly be explained by the fact that the total amount of triacylglycerol is about 5 times higher in CMC than in CEC or CFLC [the percentage of (unlabeled) AA in cardiomyocytal, CEC and CFLC triacylglycerols was approximately $3-4 \%$. However, it is noteworthy that the incorporation of labeled AA in the CMC triacylglycerol pool is appreciably higher than could be expected on the basis of relative abundance of unlabeled AA in phospholipids and triacylglycerols, as the phospholipid/triacylglycerol ratio of $\left[{ }^{3} \mathrm{H}\right]-\mathrm{AA}$ is on the order of 1 and the ratio for unlabeled AA is about 28. This difference most likely indicates that the cardiomyocytal triacylglycerol turnover is operating at a higher rate than the deacylation-reacylation cycle of membrane phospholipids. In contrast to the findings in adult cardiomyocytes, in cultured neonatal cardiomyocytes the deposition of labeled AA is most marked in the cellular phospholipid pool (10).

The relatively high rate of incorporation of labeled AA in the cellular triacylglycerol pool in adult cardiomyocytes should be taken into account when release of labeled AA from endogenous lipid pools are interpreted in terms of membrane damage evoked by insults like ischemia and reperfusion or energy depletion.

The measured FA content of the isolated $\mathrm{CMC}$, the cell type that in situ comprehends more than $75 \%$ of the cardiac volume, amounted to $2.6 \mathrm{nmol} / \mathrm{mg}$ cellular protein. This value is in agreement with findings of Myrmel and coworkers (12) and is on the average ten times higher than the FA content as determined in isolated working intact hearts $(150 \mathrm{nmol} \mathrm{FA} / \mathrm{g}$ dry weight, ref. 3 , equivalent to $0.2 \mathrm{nmol} \mathrm{FA} / \mathrm{mg}$ tissue protein). A possible explanation for this striking difference could be the mechanical inactive state in which the isolated $\mathrm{CMC}$ in culture are, compared to the working condition of isolated hearts. The rise of the FA content in isolated CMC is most likely due to the culture medium that contains fetal calf serum in which FA are present. As a consequence of the 
stationary condition, isolated CMC have lower metabolic needs and have to store the surplus of FA. This may also explain the two times higher content of the storage pool of FA, the TG, in isolated CMC compared to the size of the TG fraction of isolated working hearts (42 nmol versus $12-28 \mathrm{nmol} \mathrm{TG} / \mathrm{mg}$ tissue protein, ref. 3 ).

\subsection{SUMMARY}

The incorporation of radiolabeled anchidonic acid $\left.\left({ }^{3} \mathrm{H}\right)-\mathrm{AA}\right)$ in nomoxic $\mathrm{CMC}$, CEC and CFLC isolated from adult rat heart was studied. Deposition of [BH]-AA in the cellular lipid pool was assessed with biochemical and autoradiographic techniques.

Extraction and subsequent analysis of lipids from the three different cell types revealed that $\mathrm{CMC}$ contained significantly more triacylglycerols than CEC and CFLC. The proportion of (unlabeled) AA was also higher in triacylglycerols in CMC than in CEC and CFLC. The quantity of phospholipids did not differ among the three cell types studied. However, the content of (unlabeled) AA in the CMC phospholipid pool was twice as high as in CEC and CFLC.

The amount of $\left[{ }^{3} \mathrm{H}\right]-\mathrm{AA}$ incorporated in the cellular lipid pool of CMC, CEC and CFLC depended on the concentration of $\mathrm{AA}$ in the incubation medium and the incubation time. In CEC and CFLC incorporation of [ $\left.{ }^{3} \mathrm{H}\right]-\mathrm{AA}$ was highest in the cellular phospholipid pool $(0.01 \mu \mathrm{M}$ AA, 30 min incubation). With increased concentration of AA and longer incubation times, the cellular triacylglycerol pool became more important as site of $\left[{ }^{3} \mathrm{H}\right]-\mathrm{AA}$ incorporation. In CMC, comparable amounts of $\left[{ }^{3} \mathrm{H}\right]-A A$ were incorporated in the cellular triacylglycerol and phospholipid pools $(0.01$ and $1 \mu \mathrm{M} \mathrm{AA})$. At higher AA concentrations $(10 \mu \mathrm{M})$ the triacylglycerol pool was the preferred site of $\left[{ }^{3} \mathrm{H}\right]-\mathrm{AA}$ deposition.

Autoradiographic analysis at light and electron microscopic level revealed that the extra-nuclear space was readily stained when the three cell types were incubated with $\left[{ }^{3} \mathrm{H}\right]$-AA. These findings indicate that all cellular lipid pools and membranes are most likely site of deposition of radiolabeled arachidonic acid.

\subsection{REFERENCES}

1 Bradford MMA (1976) A rapid and sensitive method for the quantitation of microgram quantities of protein utilizing the principle of protein-dye binding. Anal Biochem 72:248-254

2 Chien KR, Han A, Sen A, Buja LM, Willerson JT (1984) Accumulation of unesterified arachidonic acid in ischemic canine myocardium. Circ Res 54: 313-322

3 De Groot MJM, Coumans WA, Willemsen PHM, van der Vusse (1993) Substrate induced changes in the lipid content of ischemic and reperfused myocardium. Its relation to hemodynamic recovery. Circ Res 72: 176-186 
4 Folch J, Lees M, Sloanc-Stanley GH (1957) A simple method for the isolation and purification of total lipids from animal tissue. J Biol Chem 226: 497-509

5 Hohl CM, Rösen P (1987) The role of arachidonic acid in rat heart cell metabolism. Biochim Biophys Acta $921: 356-363$

6 Jennings RB, Charles E, Murry MD, Steenbergen Jr, Reimer KA (1990) Development of cell injury in sustained acute ischemia. Circulation 82 Suppl II: II2-II12

7 Jennings RB, Steenbergen C, Kinney RB, Hill ML, Reimer KA (1983) Comparison of the effect of ischaemia and anoxia on the sarcolemma of the dog heart. Eur Heart J 4 (suppl): 123 137

8 Linsscen. MCJG, Vork MM, de Jong YF, Glatz JFC, van der Vusse (1990) Fatty acid oxidation capacity and fatty acid binding protein content of different cell types isolated from rat heart. Mol Cell Biochem 98: 19 -25

9 Lowry O. Rosebrough NJ, Farr AL, Randall RJ (1951) Protein measurement with the folin phenol reagent. J Biol Chem 193: 26.5-275

10 Miyazaki Y, Gross RW, Sobel BE, Saffitz JE (1987) Biochemical and subcellular distribution of arachidonic acid in rat myocardium. Am J Physiol 253: C846-C853

11 Miyazaki Y. Gross RW, Sobel BE, Saffitz. JE (1990) Selective turnover of sarcolemmal phospholipids with lethal cardiac myocyte injury. Am J Physiol 259: C325-C331

12 Myrmel T (1992) Lipid alterations in hypoxic adult rat ventricular myocytes. PhD thesis University of Troms $\phi$, Norway

13 Rodriguez-Vico F, Martinez-Cayuela M, Zafra MF, Garcia-Peregrin E, Ramirez H (1991) A procedure for the simultaneous determination of lipid and protein in biomembranes and other biological samples. Lipids 26: 77-80

14 Van Bilsen M (1988) The significance of myocardial non-esterified fatty acid accumulation during ischemia and reperfusion. PhD thesis University of Limburg, Maastricht, The Netherlands

15 Van Bilsen $M$, van der Vusse GJ, Willemsen PHM, Coumans WA, Roemen THM, Reneman RS (1989) Lipid alterations in isolated working rat hearts during ischemia and reperfusion: its relation to myocardial damage. Circ Res 64: 304-314

16 Van der Vusse GJ, Van Bilsen M, Reneman RS (1989) Is phospholipid degradation a critical event in ischemia reperfusion induced damage. News in Physiol Sci 4: 49-53

17 Van der Vusse GJ, Glatz JFC., Stam HCG, Reneman RS (1992) Fatty acid homeostasis in the normoxic and ischemic heart. Physiol Rev 72: 881-940

18 Van der Vusse GJ, Roemen THM, Prinzen FW, Coumans WA, Reneman RS (1982) Uptake and tissue content of fatty acids in dog myocardium under normoxic and ischemic conditions. Circ Res 50: 538-546

19 Verkleij AJ, Post JA (1987) Physico-chemical propertics and organization of lipids in membranes: their possible role in myocardial injury. Basic Res Cardiol 82 (suppl. 1): 85-91 


\section{CHAPTER 7}

\section{GENERAL DISCUSSION AND CONCLUSIONS}




\subsection{GENERAL DISCUSSION AND CONCLUSIONS}

The present study was performed to investigate aspects of fatty acid metabolism in cells isolated from cardiac tissue that are thought to play an important role in overall cardiac fatty acid homeostasis.

The use of isolated and/or cultivated cells, offers a possibility to identify the metabolic properties of a certain cell type in a complex organ like the heart. It cannot be neglected, however, that the application of an in vitro cell model has the disadvantage that a rather non-physiological situation is created, by disconnecting the cells from their environment and thus their endocrine, neural and other physiological regulation mechanisms. In order to perform experiments with isolated cardiac cells we developed non-contaminated cultures of cardiomyocytes (CMC), cardiac endothelial cells (CEC) and fibroblast-like cells (CFLC) from adult rat hearts. In culture more than $95 \%$ of $\mathrm{CMC}$ were rod shaped and attached to dishes; no other cell types adhered to the plates. CEC and CFLC were subcultivated to increase the number of cells, since appreciable amounts of material are needed for biochemical/physiological studies. The CEC were pure and positively characterized by endothelial markers, CFLC were identified as fibroblasts in their morphology and expression of intermediate filaments. Two stable cell lines were obtained from immortalized CEC cultures; the RHEC-50 and RHEC-116. The advantages of using cell lines is their constant behavior in growth and the possibility to generate appreciable amounts of cellular material.

Fatty acid homeostasis is characterized by a multitude of transport routes and metabolic conversions (12). One feature is myocardial fatty acid oxidation. The main locus of myocardial fatty acid oxidation is the cardiomyocyte, as indicated by the present findings. CMC contribute by about $98 \%$ to total cardiac fatty acid oxidation capacity. The contribution of other cardiac cells to this oxidation capacity is very limited which supports earlier observations (11). On the basis of the specific activity of the mitochondrial marker enzyme cytochrome $\mathrm{C}$ oxidase it can be concluded that the content of mitochondria is considerably less in CEC and CFLC than in CMC. The capacity to oxidize fatty acids is closely related to the activity of cytochrome $\mathrm{C}$ oxidase and, hence, the mitochondrial density of the cells under investigation. This conclusion is based on the findings that the palmitate oxidation rate/cytochrome $\mathrm{C}$ oxidase activity ratio in the three cell types studied is mutually not significantly different.

The transport of fatty acids from the vascular compartment is thought to be mediated by albumin in the vascular and interstitial space and by cytoplasmic fatty acid binding proteins $\left(F A B P_{c}\right)$ in the $C M C$. There is a quantitative relation between fatty acid oxidation capacity and cytoplasmic capacity to bind fatty acids (2), suggesting a close functional relationship between protein-mediated fatty acid intracellular transport, most likely by a specific $\mathrm{FABP}_{c}$, and mitochondrial fatty acid oxidation. This is in agreement with the finding that in isolated $\mathrm{CMC}$ a relatively high palmitate oxidation capacity is observed, accompanied by a relatively high content of the heart type, $\mathrm{H}-\mathrm{FABP} \mathrm{c}_{\mathrm{c}}$. However, in CEC and CFLC, 
the ratio $\mathrm{H}-\mathrm{FABP}_{\mathrm{c}}$ over palmitate oxidation was found to be significantly lower than in $\mathrm{CMC}$. The very low $\mathrm{H}-\mathrm{FABP} \mathrm{P}_{\mathrm{c}}$ levels in CEC suggest that in these cells other mechanisms are involved in the transport of fatty acids. For instance, the relative short distances between luminal and abluminal membrane probably allows transendothelial transport to occur by passive diffusion. However the presence of another, non-cardiomyocyte specific FABP, undetectable with the present techniques, has to be considered.

A physiologically important fatty acid is arachidonic acid (AA). It can be enzymatically converted to eicosanoids, compounds with specific biological activity. Cardiac tissue has the ability to produce a variety of eicosanoids from endogenous as well as exogenous AA. The capacity to synthesize eicosanoids by the various cardiac cell types was investigated on isolated cells. The findings strongly suggest that endothelial cells are the main site of cardiac eicosanoid production, although fibroblast-like cells are also capable of producing these biologically active substances in appreciable amounts. The production of eicosanoids (expressed on $\mathrm{mg}$ cellular protein) was very low in isolated CMC. The $\mathrm{Ca}^{2+}$ ionophore $\mathrm{A} 23187$ had a strong stimulating effect on eicosanoid production. The effect of more physiological agents, such as bradykinin and histamine, was less profound and depended on the cell type studied. It should be noted that the pattern of individual eicosanoids differed from cell type to cell type but also from the pattern observed in intact rat heart, perfused under ex vivo conditions. Moreover, the amount of eicosanoids produced by isolated cells under stimulating circumstances surpassed substantially the total amount of A A metabolites produced in the intact rat heart. The stable product of prostacyclin, $6-$ keto-PGF $1 \alpha$, was found to be the main product in isolated hearts, whereas $\mathrm{HHT}$, $\mathrm{PGE}_{2}, \mathrm{TxB}_{2}, 15$-HETE, 11-HETE, $\mathrm{PGF}_{2 \alpha}$ and to a lesser extent 6-keto-PGF $1 \alpha$, were the main products in isolated (and subcultivated) cells. Interestingly, the amount of 6-keto-PGF $1 \alpha$ produced by stimulated $\mathrm{CMC}$ was found to be on the same order of magnitude as the amount produced by reperfused isolated rat heart. This finding might suggest that also cardiomyocyles play a role in overall eicosanoid production in the intact heart. However, earlier studies of Hsue and colleagues (5) have convincingly shown that endothelial cells in situ play an important role in cardiac prostaglandin formation. Hence, it may be concluded that the contribution of cardiomyocytes to the release of eicosanoids in fully stimulating conditions is limited, although in situ cardiomyocytes may contribute to the overall synthesis of eicosanoids in the heart since the production in intact hearts is very low compared to the release of these compounds from isolated cells from cardiac origin.

Because of the different patterns of eicosanoids released by isolated cells, compared to intact hearts, it cannot be excluded that isolation and subcultivation of cardiac cells alter the activity of the various enzymes involved in the production of AA metabolites. In this respect the present finding, that addition of cell growth factors and heparin alters the prostacyclin production, is worth to mention. Moreover, other investigators have reported that variations in the rate 
of population doubling (6) and differences in cell density $(3,8)$ affect the amount of prostacyclin produced in vitro. Also the nature of the stimulus may also influence the most favored route in cellular eicosanoid synthesis $(1,10)$. The present results suggest that both CEC and CMC have a basal cellular eicosanoid level and that the amount of eicosanoids produced after the addition of the stimulating agent e.g. A23187 is quantitatively released into the surrounding medium. The inability of maximally stimulated isolated CMC, CEC and CFLC to produce leukotrienes strongly suggests that other cell types are responsible for the production of these substances in vivo. Mast cells commonly present in cardiac tissue (7) are likely candidates for the site of synthesis of leukotrienes in the intact rat heart.

Normally, in cardiac tissue AA is mostly present in membrane phospholipids. The features of incorporation of exogenous arachidonic acid in the lipid pools of various cardiac cell types was biochemically followed by $\left[{ }^{3} \mathrm{H}\right]$-AA incorporation in the cellular lipid pools of isolated CEC, CFLC and CMC. The label was mainly incorporated in the cellular phospholipid and triacylglycerol pool. There was a difference between CEC and CFLC on the one hand, and CMC on the other, in the relative distribution of the labeled fatty acid. In CEC and CFLC at low AA concentrations, the phospholipids were the preferred site for AA incorporation; at higher AA concentration an equal distribution of labeled AA in both pools was observed. In general the CMC phospholipid pool was earlier saturated, resulting in a more pronounced labeling of the triacylglycerol fraction. Especially at higher concentrations of AA the triacylglycerol pool was the preferred site of incorporation in CMC. This is in agreement with findings of Hohl and Rösen (4), but different from reports on neonatal CMC (9). The relatively high rate of incorporation of labeled AA in the cellular triacylglycerol pool of CMC may have consequences for the interpretation of the release of $A A$ from endogenous lipid pools as indicator of membrane damage during pathophysiological processes. Autoradiographical studies at the electron microscopic level showed that exogenous radiolabeled AA is predominantly incorporated in cellular membranes, including mitochondrial and nuclear membranes. These results confirm the biochemical findings that $A A$ is incorporated in both phospholipids and triacylglycerols.

In conclusion, the results presented indicate that the use of an in vitro cell system offers the possibility to gain more insight into cardiac fatty acid homeostasis. The cell types studied behave differently for the several investigated aspects; the CMC play a more prominent role in the myocardial palmitate oxidation, whereas the CEC and the CFLC are the more capital producers of AA metabolites. Also for uptake and incorporation in the cellular lipid pool the CMC clearly diverge from CEC and CFLC. This isolated cell model may be a helpful tool for other studies; especially for those that require a large quantity of cellular material, the use of the cell lines can be useful. However for proper interpretation of the results, the findings in the models always have to be related to the more physiological in vivo situation. 


\subsection{REFERENCES}

1 Cole O, Lewis GP (1989) Prostanoid production by rat aortic endothelial cells by bradykinin and histamine. Eur J Phamacol 169: 307-312

2 Glatz JFC, Van der Vusse GJ (1989) Intracellular transport of lipids. Mol Cell Biochem 88: $37-44$

3 Griesmacher A, Weigel G, Schreiner W. Muller MM (1989) Thromboxane A 2 generation by human umbilical endothelial cells. Thromb Res 56: 611-623

4 Hohl CM, Rosen P (1987) The role of arachidonic acid in rat heart cell metabolism. Biochim Biophys Acta 921: $356-363$

5 Hsuch W. Needleman P (1978) Sites of lipase activation and prostaglandin synthesis in isolated, perf used hearts and hydronephrotic kidneys. Prostaglandins 16:661-681

6 Ingerman-Wojenski, CM, Silver MJ (1988) Prostacyclin synthesis by endothelial cells from human umbilical veins: ffect of cumulative population doublings. Prostaglandins 36: 127-138

7 Keller AM, Clancy RM, Barr ML. Marboe CC, Cannon PJ (1988) Acute reoxygenation injury in the isolated rat heart: role of resident cardiac mast cells. Circ Res 63: 1044-1052

8 Moore SM, Spector AA, Hart MN (1988) Eicosanoid synthesis in cerebromicrovascular endothelium. Am J Physiol 254: C37-C44

9 Miyazaki Y, Gross RW, Sobel BE, Saffit JE (1987) Biochemical and subcellular distribution of arachidonic acid in rat myocardium. Am J Physiol 253: C846-C853

10 Revtyak GE., Johnson AR, Campbell WB (1988) Cultured bovine coronary arterial endothelial cells synthesize HETE's and prostacyclin. Am J Physiol 254: C8-C19

11 Spahr R, Krutzeleld A, Mertens S, Siegmund B, Piper HM (1989) Fatty acids are not an important fuel for coronary microvascular cells. Mol Cell Biochem 88: 59-64

12 Van der Vusse GJ, Glatz JFC., Stam HCG, Reneman RS (1992) Fatty acid homeostasis in the normoxic and ischemic heart. Physiol Rev 72: 881-940 


\section{SUMMARY}

In the present study a variety of aspects of fatty acid metabolism are investigated in cells isolated from cardiac tissue. First a reliable technique to isolate, subcultivate and characterize cardiomyocytes (CMC), cardiac endothelial cells (CEC) and cardiac fibroblasts (CFLC) from adult rat hearts is described. In chapter 3 continuous CEC lines obtained from CEC cultures are reported. These cell lines have shown to possess the same characteristics (presence of VWF, uptake of Dil-Ac-LDL, staining of RECA-1 and vimentin, and upregulation of membrane determinants after stimulation with IFN- $\gamma$ ) as primary cultures of freshly isolated CEC and endothelial cells in situ. These characteristics were preserved for at least more than 100 passages. Moreover, the cell lines retain a constant behavior in growth and yield a large number of cells.

Heart tissue contains an appreciable amount of cytosolic fatty acid binding protein $\left(\mathrm{H}-\mathrm{FABP} \mathrm{P}_{\mathrm{c}}\right.$ ), that is thought to play a crucial role in the transport of fatty acids from the cellular membrane to the intracellular site of oxidation. Besides, in case of endothelial cells fatty acid binding proteins are supposed to be involved in the transfer of fatty acids from the vascular to the interstitial compartment through the endothelial cytoplasm. In chapter 4 the content of $\mathrm{H}_{-} \mathrm{FABP}_{\mathrm{c}}$ in various cell types, isolated from adult rat heart, and the quantitative relationship between the capacity of different cell types in the heart to oxidize fatty acids and the presence of $\mathrm{H}-\mathrm{FABP} \mathrm{P}_{\mathrm{c}}$ is investigated. In CEC the palmitate oxidation was low compared to CMC (0.09 and $2.31 \mathrm{nmol} / \mathrm{mg}$ tissue protein, respectively). Palmitate oxidation rates were closely related to the cytochrome $\mathrm{C}$ oxidase activity and, hence, to the mitochondrial density in the cells under investigation. In $\mathrm{CMC}$ the content of $\mathrm{H}$ FABP $_{c}$ was about $4.5 \mu \mathrm{g} / \mathrm{mg}$ tissue protein. In contrast, in CEC and CFLC the $\mathrm{H}$ $\mathrm{FABP}_{\mathrm{c}}$ content was 0.008 and $0.003 \mu \mathrm{g} / \mathrm{mg}$ tissue protein, respectively, corresponding to at maximum $0.2 \%$ of the $\mathrm{H}-\mathrm{FABP} \mathrm{c}_{\mathrm{c}}$ content of $\mathrm{CMC}$. The ratio $\mathrm{H}-\mathrm{FABP}_{\mathrm{c}}$ /palmitate oxidation in CEC was found to be appreciably lower than in $\mathrm{CMC}$. These findings indicate a marked difference between $\mathrm{CMC}$ and nonmyocytal cells in the heart regarding their capacity to oxidize fatty acids, and a disproportion between the fatty acid oxidation capacity and the cellular content of immunochemically determined H-FABP, suggesting that other mechanisms than involvement of $\mathrm{H}-\mathrm{FABP}_{\mathrm{c}}$ are responsible for the transport of fatty acids in endothelial cells.

The capacity of various cell types, isolated from adult rat heart, to synthesize eicosanoids is described in chapter 5. Cells were routinely incubated in the presence of the $\mathrm{Ca}^{2+}$ ionophore $\mathrm{A} 23187(10 \mu \mathrm{M})$ and exogenous arachidonic acid (AA, $80 \mu \mathrm{M}$ ). The release of total eicosanoids in the incubation medium amounted to $23.3 \pm 4.5$ and $2.0 \pm 0.4 \mathrm{nmol} / \mathrm{mg}$ cellular protein per $30 \mathrm{~min}$ in subcultivated CEC and CFLC, respectively. The release in isolated CMC remained below the detection limit of the HPLC assay technique applied. With the more sensitive RIA technique CMC were found to release $2 \mathrm{pmol} / \mathrm{mg}$ protein per 30 min 6-keto-PGF ${ }_{1 \alpha}$, the stable degradation product of prostacyclin. $\mathrm{PGE}_{2}$, 
$\mathrm{PGF}_{2 \alpha}, 12-\mathrm{HHT}, 11$ - and $15-\mathrm{HETE}$ and $\mathrm{TxB}_{2}$ were the main eicosanoids released by endothelial cells. 6-Keto- $\mathrm{PGF}_{1 \alpha}$ contributed relatively little to the total amount of eicosanoids formed by CEC ( $120 \mathrm{pmol} / \mathrm{mg}$ protein per $30 \mathrm{~min})$. CFLC released predominantly $\mathrm{PGE}_{2}$ and 6 -keto- $\mathrm{PGF}_{1 \alpha}$ and to a lesser extent $12-\mathrm{HHT}$ and 15-HETE. Neither CEC nor CFLC released leukotrienes. Because CEC were the main eicosanoid producing cells in vitro, the effect of the extracellular stimulants AA and A23187 was studied in more detail in this cell type. So the influence of the AA concentration and the duration of the incubation was followed in CEC. The effect of the physiologically relevant stimuli histamine and bradykinin was studied in both CEC and CMC in comparison with A23187. Histamine and bradykinin did not significantly increase the release of 6-keto$\mathrm{PGF}_{1 \alpha}$ or $\mathrm{PGE}_{2}$ in $\mathrm{CMC}$. Only histamine gave rise to a slight, but significant higher release of 6-keto-PGF $1 \alpha$ in CEC. The cellular content of 6-keto-PGF $1 \alpha$ and $\mathrm{PGE}_{2}$ was not influenced by addition of bradykinin, histamine or A23187 to the incubation medium. In cultured cells the amount of eicosanoids released after stimulation was many times more compared to the amount released by stimulated intact hearts.

In chapter 6 the incorporation of radiolabeled arachidonic acid $\left(\left[{ }^{3} \mathrm{H}\right]-\mathrm{AA}\right)$ in normoxic CMC, CEC and CFLC isolated from adult rat heart is summarized. Deposition of $\left[{ }^{3} \mathrm{H}\right]-\mathrm{AA}$ in the cellular lipid pool was assessed with biochemical and autoradiographic techniques. Extraction and subsequent analysis of lipids from the three different cell types revealed that $\mathrm{CMC}$ contained significantly more triacylglycerols than CEC and CFLC. The proportion of (unlabeled) AA was also higher in triacylglycerols in CMC than in CEC and CFLC. The quantity of phospholipids did not differ among the three cell types studied. However, the content of (unlabeled) AA in the CMC phospholipid pool was twice as high as in CEC and CFLC. The amount of $\left[{ }^{3} \mathrm{H}\right]-\mathrm{AA}$ incorporated in the cellular lipid pool of CMC, CEC and CFLC depended on the concentration of AA in the incubation medium and the incubation time. In CEC and CFLC incorporation of $\left[{ }^{3} \mathrm{H}\right]-\mathrm{AA}$ was highest in the cellular phospholipid pool. With increasing concentrations of $\mathrm{AA}$ and longer incubation times, the cellular triacylglycerol pool became more important as site of $\left[{ }^{3} \mathrm{H}\right]-\mathrm{AA}$ incorporation. In $\mathrm{CMC}$, comparable amounts of $\left[{ }^{3} \mathrm{H}\right]-$ AA were incorporated in the cellular triacylglycerol and phospholipid pools. At higher AA concentrations $(10 \mu \mathrm{M})$ the triacylglycerol pool was the preferred sitc of $\left[{ }^{3} \mathrm{H}\right]-A A$ deposition. Autoradiographic analysis at light and electron microscopic level revealed that the extra-nuclear space was readily stained when the three cell types were incubated with $\left[{ }^{3} \mathrm{H}\right]-\mathrm{AA}$. These findings indicate that all cellular lipid pools and membranes are the most likely site of deposition of radiolabeled arachidonic acid. 


\section{SAMENVATTING}

In deze studie zijn bepaalde aspecten van het vetzuurmetabolisme onderzocht in cellen geisoleerd uit volwasen rattehartweefsel. Allereerst is een techniek beschreven om cardiomyocyten (CMC), cardiale endotheelcellen (CEC) en fibroblasten (CFLC) uit volwassen ratteharten te isoleren, in kweek te brengen en te karakteriseren. Continue cellijnen, ontstaan uit CEC culturen, zijn in hoofdstuk 3 beschreven. De cellijnen blijken dezelfde endotheliale karakteristieken te bezitten als primaire culturen van CEC en endotheelcellen in situ. Te weten: aanwezigheid van Von Willebrand factor en vimentine, en kleuring tegen een specifiek rat endotheelcel antigeen. Voorts hebben de cellen uit deze lijnen het vermogen om Dil-acetylated low density lipoproteine op te nemen, en vertonen zij een toename in expressie van membraan determinanten na stimulatie met interferon $\gamma$. Deze endotheliale kenmerken werden voor meer dan honderd passages behouden. Een voordeel van deze cellijnen is dat ze een constant groei gedrag hebben en dat ze grote hoeveelheden cellen kunnen opbrengen.

In hartweefsel is een aanzienlijke hoeveetheid cytosolisch vetzurbindend eiwit $\left(\mathrm{H}-\mathrm{FABP}_{\mathrm{c}}\right)$ aangetoond. Aan dit eiwit wordt een belangrijke rol toegeschreven bij het transport van vetzuren in cardiomyocyten, van de celmembraan naar de intracellulaire plaats van oxidatie, de mitochondrieën, en in endotheelcellen, bij de overdracht van vetzuren van de vasculaire naar de interstitiële ruimte via het cytoplasma van de endotheelcel. In hoofdstuk 4 is het gehalte aan $\mathrm{H}$-FABP $\mathrm{c}$ in de verschillende celtypen, geïsoleerd uit ratteharten, en de quantitatieve relatie tussen capaciteit van de verschillende cellen om vetzuren te oxideren en de aanwezigheid van $\mathrm{H}-\mathrm{FABP}_{\mathrm{c}}$ beschreven. In CEC was de palmitaat oxidatie laag vergeleken met die in CMC (respectievelijk 0.09 en $2.31 \mathrm{nmol} / \mathrm{mg}$ weefsel eiwit). De palmitaat oxidatie waarden blijken goed te correleren met de activiteit van het cytochroom $C$ oxydase, en dus met de mitochondrieèle dichtheid van de onderzochte cellen. In $\mathrm{CMC}$ was het gehalte aan $\mathrm{H}-\mathrm{FABP}_{\mathrm{c}}$ ongeveer $4.5 \mu \mathrm{g} / \mathrm{mg}$ cellulair eiwit. In CEC and CFLC echter was het H-FABP $\mathrm{c}_{c}$ gehalte respectievelijk maar 0.008 en 0.003 $\mu \mathrm{g} / \mathrm{mg}$ cellulair eiwit, hetgeen overeenkomt met maximaal $0.2 \%$ van de hoeveelheid $\mathrm{H}-\mathrm{FABP} \mathrm{c}_{\mathrm{c}}$ aanwezig in $\mathrm{CMC}$. Dit wijst op een aanzienlijk verschil tussen CMC en niet-myocyten in capaciteit om vetzuren te oxideren en een disproportie tussen de vetzuuroxidatie capaciteit en immunochemisch bepaalde gehalte aan $\mathrm{H}-\mathrm{FAPB}_{\mathrm{c}}$. Bij het vetzuur transport in endotheelcellen lijken dan ook andere mechanismen betrokken te zijn dan transport via $\mathrm{H}-\mathrm{FABP}_{\mathrm{c}}$.

Voor het hart is arachidonzuur (AA) een belangrijk vetzuur. AA is een bouwsteen van membranen en kan omgezet worden tot eicosanoïden, stoffen met verschillende fysiologische effecten. De capaciteit van de verschillende celtypen om eicosanoïden te synthetiseren is bestudeerd in hoofdstuk 5. De cellen werden hiertoe routinematig geïncubeerd in de aanwezigheid van $\mathrm{Ca}^{2+-j o n o f o r} \mathrm{~A} 23187$ $(10 \mu \mathrm{M})$ en exogeen AA $(80 \mu \mathrm{M})$. De totale afgifte van eicosanoïden aan het medium bedroeg $23.3 \pm 4.5$ en $2.0 \pm 0.4 \mathrm{nmol} / \mathrm{mg}$ cellulair eiwit per $30 \mathrm{~min}$ in gekweekte CEC en CFLC respectievelijk. In geïsoleerde CMC kon de hoeveelheid 
afgegeven eicosanoiden niet gedetecteerd worden met de HPLC techniek. Werd echter met de gevoelige RIA techniek het gehalte aan 6-keto-PGF $1 \alpha$, het stabiele degradatie produkt van prostacycline, gemeten, dan bleek dit $2 \mathrm{pmol} / \mathrm{mg}$ eiwit per 30 min te zijn. PGE $, \mathrm{PGF}_{2 \varkappa}, 12-\mathrm{HHT}, 11$ - en 15-HETE en TxB $\mathrm{C}_{2}$ waren de belangrijkste eicosanoiden gevormd door de endotheelcellen. 6-Keto- $\mathrm{PGF}_{1 \alpha}$ droeg relatief weinig bij aan aan de totale hoeveelheid eïcosanoiden door CEC geproduceerd. CFLC produceerden voornamelijk $\mathrm{PGE}_{2}$ en 6-keto-PGF $\mathrm{P}_{1 \alpha}$ en in mindere mate 12-HHT en 15-HETE. Noch bij CEC, noch bij CFLC kon een meetbare productie van leukotrienes aangetoond worden. Omdat CEC de voornaamste eicosanoid producerende cellen in vitro zijn, is het effect van de extracellulaire stimuli AA en A23187 uitgebreid bestudeerd in dit cell type. Zo werden variaties in de incubatieduur en in AA concentratie bekeken. Het effect van de meer fysiologische stimuli histamine en bradykinine is onderzocht in zowel CEC als CMC en vergeleken met A23187 stimulatie. Histamine en bradykinine veroorzaakten geen significante toename in 6-keto-PGF ${ }_{1 \alpha x}$ en $\mathrm{PGE}_{2}$ afgifte in CMC. Alleen in CEC gaf histamine een kleine, maar significante, verhoging in de productie van 6 -keto- $\mathrm{PGF}_{\mathrm{I} \alpha}$ te zien. Het cellulaire gehalte van beide celtypen aan 6-keto-PGF $\mathrm{PF}_{1 \alpha}$ en $\mathrm{PGE}_{2}$ werd niet beinvloed door toevoeging van bradykinine, histamine of A23187 aan het incubatiemedium. De hoeveelheid eicosanoïden in vitro geproduceerd na maximale stimulatie overtreft die van gestimuleerde intacte harten vele malen.

De inbouw van radioactief gemerkt arachidonzuur $\left(\left[{ }^{3} \mathrm{H}\right]-\mathrm{AA}\right)$ en de hoeveelheid $\mathrm{AA}$ aanwezig in de verschillende lipide pools in normoxische $\mathrm{CMC}, \mathrm{CEC}$ en CFLC geisoleerd uit volwassen ratteharten is beschreven in hoofdstuk 6. De meting van de hoeveelheid ingebouwde $\left[{ }^{3} \mathrm{H}\right]-\mathrm{AA}$ in de cellulaire lipide pools is uitgevoerd met biochemische en autoradiografische technieken. Extractie en analyse van de lipiden van de drie verschillende celtypen liet zien dat $\mathrm{CMC}$ significant meer triacylglycerolen bevatten dan CEC en CFLC. De grootte van de fosfolipide pools (uitgedrukt per mg cellulair eiwit) verschilde niet in de bestudeerde celtypen. Echter, het gehalte aan niet-radioactief gemerkt AA in de CMC fosfolipide pool was twee keer zo hoog als in de CEC en CFLC. De hoeveelheid ingebouwde $\left[{ }^{3} \mathrm{H}\right]-\mathrm{AA}$ in de cellulaire lipide pool hing af van de concentratie van $\mathrm{AA}$ in het incubatiemedium en van de incubatieduur. In $\mathrm{CEC}$ en CFLC was de inbouw van $\left[{ }^{3} \mathrm{H}\right]-\mathrm{AA}$ het hoogste in de cellulaire fosfolipide pool. Met toenemende concentratie van AA en langere incubatietijden werd de triacylglycerol pool belangrijker voor inbouw van $\left[{ }^{3} \mathrm{H}\right]-\mathrm{AA}$. In $\mathrm{CMC}$ werden vergelijkbare hoeveelheden $\left[{ }^{3} \mathrm{H}\right]-\mathrm{AA}$ in de cellulaire triacylglycerol en fosfolipide pool ingebouwd. Bij hogere concentraties $\mathrm{AA}(10 \mu \mathrm{M})$ was de triacylglycerol pool de voorkeursplaats voor de inbouw van radioactief gemerkt AA. Autoradiografische analyse op licht- en elektronenmicroscopisch niveau liet zien dat de extra-nucleaire ruimte van de drie bestudeerde celtypen de plaats is waar na incubatie met $\left[{ }^{3} \mathrm{H}\right]-A A$ en blootstelling aan fotografische emulsie zwarte korrels worden gevormd. Deze bevindingen wijzen in de richting van een inbouwen van het radioactief gemerkte AA in alle cellulaire lipide pools en membranen. 


\section{LIST OF PUBLICATIONS}

\section{Papers}

Linssen MCJG, Vork MM, de Jong YF, Glatz JFC, van der Vusse GJ. Fatty acidoxidation capacity and fatty-acid binding protein content of different cell types isolated from adult rat heart. Mol Cell Biochem 98: 19-25, 1990.

Linssen MCJG, Willemsen PHM, Heijnen VVTh, van der Vusse G.J. A rachidonic acid incorporation in cardiomyocytes, endothelial cells and fibroblast-like cells isolated from adult rat heart. Mol Cell Biochem 116: 203-209, 1992.

Linssen MCJG, Engels W, Lemmens PJMR, Heijnen VVTh, van Bilsen M, van der Vusse GJ, Reneman RS. Production of arachidonic acid metabolites in adult rat cardiac myocytes, endothelial cells and fibroblast-like cells. Am J Physiol 264: H973.H982, 1993.

Linssen $M C J G$, van Nieuwenhoven FA, Duijvestijn AM, Glatz JFC, van der Vusse GJ. Continuous endothelial cell lines obtained from adult rat heart. In Vitro Cell Dev Biol 29A: 61 1-613, 1993.

Caldwell JH, Mertens $H$, Linssen $M C J G$, van der Vusse GJ, Buell U, Kammermeier $\mathrm{H}$. Uptake kinectics of Technetium-99m-methoxyisobutylisonitrile and Thallium-201 in adult rat heart endothelial and fibroblast-like cells in comparison to myocytes. J Nucl Med 33: 102-107, 1992.

\section{Abstracts}

Linssen MCJG, Lemmens PJMR, van Bilsen M, Engels W, van der Vusse GJ. Arachidonic acid-metabolites produced in cells isolated from rat hearts. J Mol Cell Cardiol 21 (S IV): S77, 1989.

Linssen $M C J G$, Vork MM, de Jong YF, Glatz JFC, van der Vusse GJ. Fatty acidoxidation capacity and FABP content in different cell types isolated from rat heart. FABP workshop, Maastricht, 4-5 sept. 1989.

Linssen $M C J G$, Engels W, Lemmens PJMR, van Bilsen M, van der Vusse GJ, Reneman RS. Arachidonic acid (AA) metabolism in cells isolated from adult rat hearts. FASEB J 4(3): A418, 1990.

Linssen $M C J G$, Engels W, Lemmens PJMR, van Bilsen $\mathrm{M}$, van der Vusse GJ, Reneman RS. Arachidonic acid (AA) metabolism in cells isolated from adult rat hearts. Pflügers Archiv Europ J Physiol 416: 7, 1990.

Caldwell JH, Mertens H, Linssen $M$, van der Vusse G, Buell U, Kammermeier H. $99 \mathrm{mTc}-\mathrm{MIBI}$ and $201 \mathrm{Tl}$ uptake in rat heart microvascular endothelial and fibroblast-like cells compared to myocytes. Submitted for the American Heart Association, 12-15 nov. 1990, Dallas, Texas, USA.

Stuart MCA, Bomans PHH, Linssen $M C J G$, Frederik PM. Cryoelectron microscopy of vitrified "whole cells". Najaars vergadering, Ned Ver Elektronenmicrosc, dec. 1990. 
Linssen MCJG, Willemsen PHM, Heijnen VVTh, van der Vusse GJ. Incorporation of arachidonic acid in isolated cardiomyocytes, endothelial cells and fibroblastlike cells from adult rat heart. J Mol Cell Cardiol 23 (S V): S97, 1991.

Linssen MCJG, Willemsen PHM, Heijnen VVTh, van der Vusse GJ. Arachidonic acid incorporation in different cell types from adult rat heart. J Mol Cell Cardiol 24 (S I): S184, 1992.

Thomas J, Linssen $M$, van der Vusse G, Kammermeier H, Fischer Y. Acute stimulation of glucose transport in microvascular cardiac endothelial cells by histamine. Pflügers Archiv Europ J Physiol 422 (S1): 449, 1993. 


\section{CURRICULUM VITAE}

8 Oktober 1959

Sept. 1972 - mei 1978

Sept. 1978 - nov. 1986 geboren te Venlo

atheneum B, Scholengemeenschap St. Thomascollege, Venlo

studie Biologie, Katholieke Universiteit Nijmegen hoofdvak: Dierfysiologie (Prof. Dr. S.E. Wendelaar Bonga)

bijvakken: Anatomie/Embryologie (Prof. Dr. J.M.G. Kauer) en Ontwikkelingsbiologie der dieren (Prof. Dr. J.M. Denucé)

Vakdidaktiek en Algemene Onderwijskunde (Drs. R.M.L.A. Dolné en Prof. A.M.P. Knoers)

Febr. 1987 - nov. 1993 promotieonderzoek, Rijksuniversiteit Limburg 
Dafawyse I Universitaire Pers Maastricht ISBN 9052781044 